\title{
Annotated checklist of the freshwater fishes of continental and insular Costa Rica: additions and nomenclatural revisions
}

\author{
Arturo Angulo ${ }^{1 *}$, Carlos A. Garita-Alvarado ${ }^{1}$, William A. Bussing ${ }^{1,2}$ and Myrna I. López ${ }^{1,2}$ \\ 1 Museo de Zoología, Escuela de Biología, Universidad de Costa Rica, San Pedro de Montes de Oca, San José, Costa Rica, 11501-2060. \\ 2 Centro de Investigaciones en Ciencias del Mar y Limnología (CIMAR), Universidad de Costa Rica, San Pedro de Montes de Oca, San José, Costa \\ Rica, 11501-2060. \\ * Corresponding author. E-mail: arturo.angs@gmail.com
}

\begin{abstract}
Based on a combination of intensive literature review, electronic database searches, re-identification of museum specimens and fieldwork, we hereby provide an updated checklist of the freshwater fishes of continental and insular Costa Rica. This checklist, systematically arranged at the ordinal and familial level, includes nomenclatural revisions, distributional information, and when appropriate, cross-references on the basis of Bussing (1998). According to our results, the native Costa Rican freshwater fish fauna is composed by 250 species, divided into 119 genera, 49 families and 19 orders; increasing in 108 the number of species originally reported by Bussing (1998). By far, the vast majority of these species, according to their supposed tolerance to salinity, are peripheral (63.2\%), followed by secondary freshwater fishes (23.6\%); only $13.2 \%$ are primary freshwater fishes. 24 species in this checklist appear to be endemic to Costa Rica. In addition to the native fauna 8 exotic species are reported.
\end{abstract}

\section{INTRODUCTION}

Despite the relatively small continental size of Costa Rica, the country has a rich freshwater fish fauna, which was originally covered by Bussing (1987; 1998). Since these pioneer works, knowledge about the freshwater fishes of the country has continues to grow. The discovery of new species, the establishment of new inland and country records, and the numerous nomenclatural changes for previously known species, given major advances in understanding of the status and relationships of many groups, contribute to such development. The purpose of the following checklist is to update the known composition of the Costa Rican freshwater fish fauna, as well as provide revisions in nomenclature that reflect the well supported conclusions of recent studies on relationships.

\section{MATERIALS AND MethodS}

Diversity and distributional data were obtained by several methods. First, field sampling at different localities in Costa Rica was performed between March 2009 and January 2013. Sampling gear included seines, cast nets and backpack electrofishers. Collection and research permits (No-152-2009-SINAC, No-181-2010SINAC, No 157-2012-SINAC and No 007-2013-SINAC) were issued by the Costa Rican Ministerio de Ambiente Energía y Telecomunicaciones (MINAET) and the Sistema Nacional de Áreas de Conservación (SINAC). Parallel, a thorough review of the scientific literature and Costa Rican freshwater fish holdings at the collection of the Museo de Zoología of the Universidad de Costa Rica (UCR) was conducted. Finally, species occurrence records were also obtained by querying the inter-institutional online database FishNet2 (www.fishnet2.net) in order to supplement the data obtained by the above sources.

Specimens preserved were deposited at UCR and
Louisiana State University Museum of Zoology (LSUMZ). Other institutional abbreviations used are as follows: CAS = California Academy of Sciences; LACM = Los Angeles County Museum; STRI = Smithsonian Tropical Research Institute; $\mathrm{TU}=$ Tulane University Museum of Natural History; UF = University of Florida; and UMMZ = University of Michigan Museum of Zoology.

The checklist is arranged by order and family following Eschmeyer and Fong (2013). Genera and species within a family are arranged in alphabetical order. After the mention of each most inclusive taxa, the number in parentheses indicates the number of species. In classification categories larger than genera the number in brackets represent the number of genera. In those higher than family the number preceding genera is the number of families.

The family tolerance to salinity is listed according to the classification of Myers (1949). Authority and year of description of each species and genera follow Eschmeyer (2013). An asterisk after the authority name indicates that the taxon is introduced. When available, after the authority name, the common English name was provided followed by the common Spanish name, both following Bussing (1998), Bussing and López $(1994,2010)$ and Froese and Pauly (2013) (see Angulo (2013) for a more complete list of the common and technical Spanish names of the Costa Rican freshwater fishes). The number within parenthesis following the common names indicates the page location for the appropriate account in Bussing (1998).

Distributional data are presented at the Costa Rican major River drainage basins (Figure 1), for which there are records for the species (Atlantic slope before Pacific slope drainages, all listed in north to south order). Following the distributional data, altitudinal ranges in meters above sea level are also presented. For range expansions and additions to freshwater fish fauna, on the basis of 
Bussing (1998), we list the individual papers and/or museum specimens that are associated with the species of interest. Finally, comments are provided for species where annotations are necessary in the remarks section (e.g. nomenclatural notes, range extensions, conservation status, etc.).

\section{RESULTS}

The native freshwater fish fauna of Costa Rica is composed by 250 species included in 119 genera, 49 families and 19 orders (Table 1). The order Perciformes, with 123 species in 17 families, is the most diverse, followed by Cyprinodontiformes (33 species in 4 families) and Characiformes ( 22 species in 4 families). Cichlidae (25 species), Poeciliidae (23 species), Gobiidae (22 species), Characidae (19 species) and Eleotridae (16 species) are the most speciose families. By far, the vast majority of Costa Rican freshwater fish species, according to their supposed tolerance to salinity, are peripheral (63.2\%), followed by secondary (23.6\%); only $13.2 \%$ are primary or obligate freshwater.

A total of 108 species in this checklist constitute additions to the Bussing (1998) list. Of these, 105 are peripheral species, two (Ophisternon aenigmaticum and Poeciliopsis santaelena) are secondary species and only Bryconamericus gonzalezi is a primary species. Twenty-four species appear to be endemic to the country (Amphilophus bussingi, A. diquis, Brachyrhaphis olomina, B. rhabdophora, Bryconamericus terrabensis, Cryptoheros myrnae, C. sajica, Cynodonichthys fuscolineatus, C. glaucus, C. siegfriedi, Eleotris tubularis, Gobiesox fulvus, Hyphessobrycon savagei, Imparfinis lineatus, Lebiasina boruca, Phallichthys

$86^{\circ}$ $85^{\circ}$

$84^{\circ}$ $83^{\circ}$

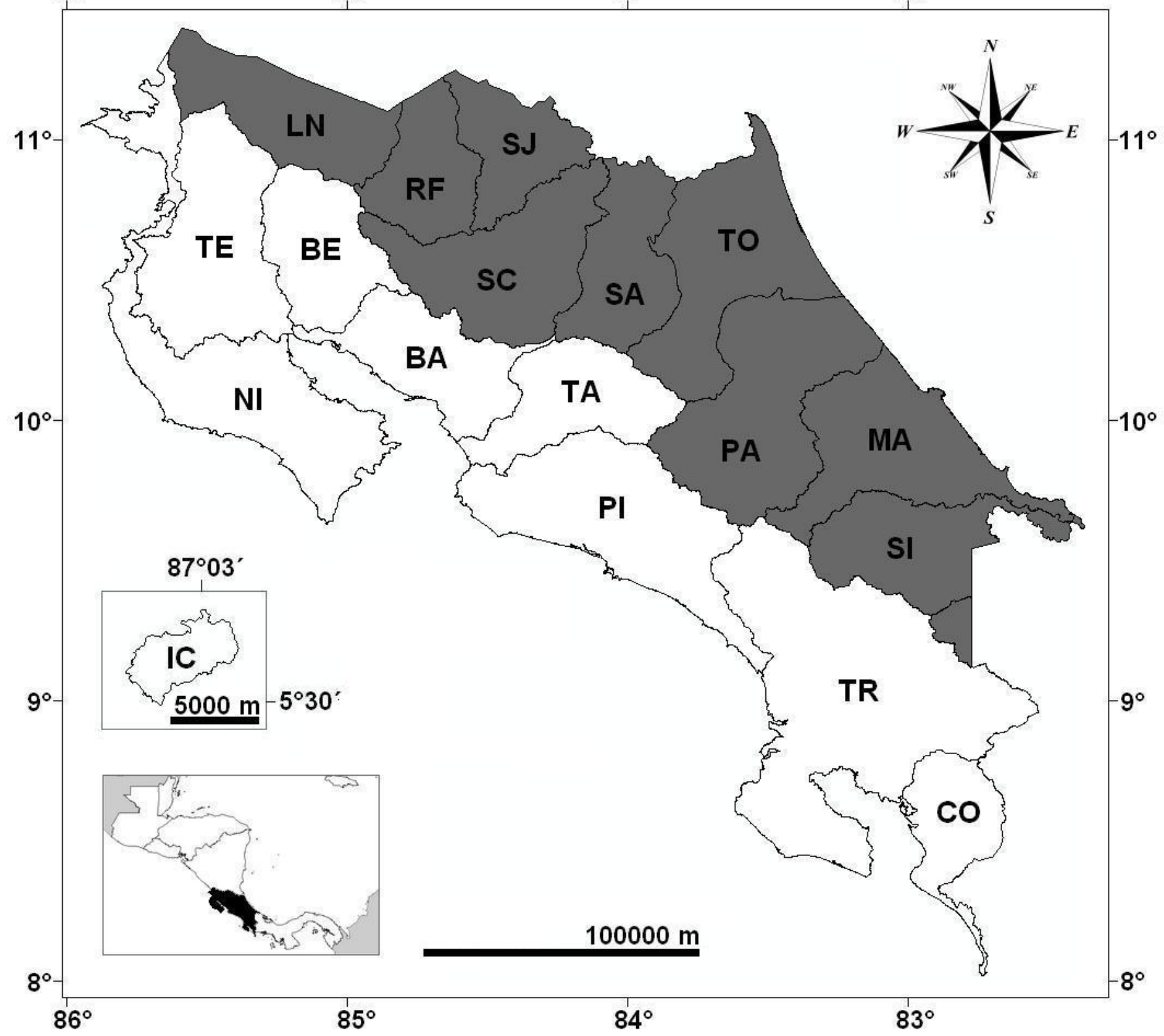

FIGURE 1. Map of Costa Rica showing the 18 major River drainage basins. Unshaded areas depict drainages located on the Pacific slope; shaded areas are on the Atlantic Slope. Major River drainage basins: Lago de Nicaragua (LN), Río Frío (RF), San Juan (SJ), San Carlos (SC), Sarapiquí (SA), Tortuguero (TO), Parismina (PA), Matina (MA), Sixaola (SI), Isla del Coco (IC), Nicoya (NI), Tempisque (TE), Bebedero (BE), Barranca (BA), Tárcoles (TA), Pirrís (PI), Térraba (TR) and Coto (CO). 
quadripunctatus, Poeciliopsis paucimaculata, P. santaelena, Priapichthys annectens, Pseudocheirodon Térrabae, Pterobrycon myrnae, Roeboides ilseae, Sicydium adelum and $S$. cocoensis). Finally, in addition to the native species, 8 exotic species (Carassius auratus, Cyprinus carpio, Micropterus salmoides, Oncorhynchus mykiss, Oreochromis niloticus, Poecilia reticulata, Pterygoplichthys pardalis and Xiphophorus variatus), included in eigth genera, three families and two orders, are also found in the country.

ANNOTATED CHECKLIST OF THE FRESHWATER FISHES OF CONTINENTAL AND INSULAR CoSTA RICA 52[127](258)

Class: Elasmobranchil 2[2](3).

Order: Carcharhiniformes 1[1](1).

Family: Carcharhinidae [1](1). Peripheral.

\section{Genus: Carcharhinus Blainville, 1816 (1)}

1. Carcharhinus leucas (Müller and Henle, 1839). Bull shark, tiburón toro (51).

Distribution: Atlantic slope: Lago de Nicaragua, Río Frío, San Juan, San Carlos, Sarapiquí and Tortuguero. Pacific slope: Térraba. 0-35 m.

Order: Pristiformes 1[1](2).

Family: Pristidae [1](2). Peripheral.

\section{Genus: Pristis Linck, 1790 (2).}

2. Pristis pectinata Latham, 1794. Smalltooth sawfish, pez sierra. Addition to fauna.

Distribution: Atlantic slope: Lago de Nicaragua, San Juan and Tortuguero. Pacific slope: Térraba. 0-35 m.

Remarks: This species has been reported in the Caribbean coast of Costa Rica by Bussing and López (2009; 2010). Thorson (1976) recorded this species in freshwaters near the outlets of the San Juan River, Nicaragua, and its major branch, the Colorado River, Costa Rica. Other freshwater records in Caribbean drainages of Central America include the Lake Izabal and the Dulce River, Guatemala (Thorson et al. 1966), and the Patuca River, Honduras (Matamoros et al. 2009). In addition, Winemiller (1983) recorded this species in freshwaters in the Claro River, Térraba drainage, Pacific slope.

3. Pristis pristis (Linnaeus, 1758). Common sawfish, pez sierra (53).

Distribution: Atlantic slope: Lago de Nicaragua, Río Frío, San Juan, San Carlos, Sarapiquí and Tortuguero. Pacific slope: Tempisque. 0-35 m.

Class: ACTINOPTERYgiI 50[125](255).

Order: Lepisosteiformes 1[1](1).

Family: Lepisosteidae [1](1). Secondary.

Genus: Atractosteus Rafinesque, 1820 (1).
(57).

4. Atractosteus tropicus Gill, 1863. Tropical gar, gaspar

Distribution: Atlantic slope: Lago de Nicaragua, Río Frío, San Juan, San Carlos, Sarapiquí, Tortuguero and Parismina. 0-45 $\mathrm{m}$.

Order: Elopiformes 2[2](2).

Family: Elopidae [1](1). Peripheral.

Genus: Elops Linnaeus, 1766 (1).

5. Elops affinis Regan, 1909. Pacific ladyfish, macabí. Addition to fauna.

Distribution: Pacific slope: Nicoya. 0-10 m.

Remarks: This species has been reported in the Pacific coast of Costa Rica by Bussing and López (1994; 2009; 2011). Eight specimens have been collected in freshwaters in the Calera River (UCR 0935-06), Nicoya drainage.

Family: Megalopidae [1](1). Peripheral.

Genus: Megalops Lacepède, 1803 (1).

6. Megalops atlanticus Valenciennes, 1847. Tarpon, sábalo real (61).

Distribution: Atlantic slope: Lago de Nicaragua, Río Frío, San Juan, San Carlos, Sarapiquí and Tortuguero. 0-45 m.

\section{Order: Albuliformes 1[1](1).}

Family: Albulidae [1](1). Peripheral.

Genus: Albula Scopoli, 1777 (1).

7. Albula vulpes (Linnaeus, 1758). Bonefish, zorro. Addition to fauna.

Distribution: Atlantic slope: Matina. 0-2 m.

Remarks: This species has been reported in the Caribbean coast of Costa Rica by Bussing and López (2009; 2010). Four specimens have been collected in freshwaters in the Suarez River (UCR 0211-05), Matina drainage.

\section{Order Anguilliformes 2[2](3).}

Family Anguillidae [1](1). Peripheral.

\section{Genus: Anguilla Schrank, 1798 (1).}

8. Anguilla rostrata (Lesueur, 1817). American eel, anguila (64).

Distribution: Atlantic slope: Lago de Nicaragua, Río Frío, San Juan, San Carlos, Sarapiquí, Tortuguero, Parismina, Matina and Sixaola. 0-20 m.

Family: Ophichthidae [1](2). Peripheral.

Genus: Myrophis Lütken, 1852 (2).

9. Myrophis punctatus Lütken, 1852. Speckled worm eel, tieso gusano. Addition to fauna. 
Distribution: Atlantic slope: Matina. 0-3 m.

Remarks: This species has been reported in the Caribbean coast of Costa Rica by Bussing and López (2009; 2010). Seven specimens have been collected in freshwaters in the Suarez River (UCR 0778-12, $n=6$, UCR 0779-05, n=1), Matina drainage.

10. Myrophis vafer Jordan and Gilbert, 1883. Pacific worm eel, anguila lombriz común. Addition to fauna.

Distribution: Pacific slope: Térraba. 0-17 m.

Remarks: This species has been reported in the Pacific coast of Costa Rica by Bussing and López (1994; 2009; 2011). One specimen has been collected in freshwaters in the Quebrada Sucia River (UCR 1314-21), Térraba drainage.

\section{Order: Clupeiformes 2[7](8).}

Family: Clupeidae [3](4). Peripheral.

\section{Genus: Dorosoma Rafinesque, 1820 (1).}

11. Dorosoma chavesi Meek, 1907. Nicaragua gizzard shad, sabalete (68).

Distribution: Atlantic slope: Lago de Nicaragua, Río Frío, San Juan, San Carlos, Sarapiquí and Tortuguero. 0-50 m.

\section{Genus: Lile Jordan and Evermann, 1896 (2).}

12. Lile piquitinga (Schreiner and Miranda Ribeiro, 1903). Atlantic piquitinga, sardina piquitinga. Addition to fauna.

Distribution: Atlantic slope: Sixaola. 0-66 m.

Remarks: One specimen has been collected in freshwaters in the Quebrada Biei River (UCR 1531-10), Sixaola drainage. This species is known only from Nueva Esparta, Venezuela, and the coasts of Brazil from Racife and Lake Papary near Natal south to Bahia and Espirito Santo (Cervigón et al. 1992); this specimen represents a north range extension of the known distribution in the western Atlantic.

13. Lile stolifera (Jordan and Gilbert, 1882). Striped herring, sardina rayada. Addition to fauna.

Distribution: Pacific slope: Térraba. 0-10 m.

Remarks: This species has been reported in the Pacific coast of Costa Rica by Bussing and López (1994; 2009; 2011). Forty-eight specimens have been collected in freshwaters in the Rincón River (UCR 0262-09, n=21, UCR 0456-06, n=26) and the Sierpe River (UCR 2863-01, n=1), Térraba drainage.

\section{Genus: Sardinella Valenciennes, 1847 (1).}

14. Sardinella brasiliensis (Steindachner, 1879). Brazilian sardinella, sardina brasileña. Addition to fauna.

Distribution: Atlantic slope: Tortuguero. 0-3 m.

Remarks: This species has been reported in the Caribbean coast of Costa Rica by Bussing and López (2009; 2010). Eight specimens have been collected in freshwaters in the Tortuguero Lagoon (UCR 1788-05), Tortuguero drainage.

Family: Engraulidae [4](5). Peripheral.

\section{Genus: Anchoa Jordan and Evermann, 1927 (2).}

15. Anchoa curta (Jordan and Gilbert, 1882). Short anchovy, anchoa pelada. Addition to fauna.

Distribution: Pacific slope: Térraba. 0-12 m.

Remarks: This species has been reported in the Pacific coast of Costa Rica by Bussing and López (1994; 2009; 2011). Alpírez (1985) recorded this species in freshwaters in the Palo Seco River and the Quebrada Vueltas River, Térraba drainage.

16. Anchoa lucida (Jordan and Gilbert, 1882). Bright anchovy, anchoa bocona. Addition to fauna.

Distribution: Pacific slope: Barranca. 0-32 m.

Remarks: This species has been reported in the Pacific coast of Costa Rica by Bussing and López (1994; 2009; 2011). One specimen has been collected in freshwaters in the Lagarto River (UCR 1268-20), Barranca drainage.

\section{Genus: Anchovia Jordan and Evermann, 1895 (1).}

17. Anchovia macrolepidota (Kner, 1863). Bigscale anchovy, anchoa de escama grande. Addition to fauna.

Distribution: Pacific slope: Térraba. 0-17 m.

Remarks: This species has been reported in the Pacific coast of Costa Rica by Bussing and López (1994; 2009; 2011). One specimen has been collected in freshwaters in the Quebrada Sucia River (UCR 1314-18), Térraba drainage.

\section{Genus: Anchoviella Fowler, 1911 (1).}

18. Anchoviella elongata (Meek and Hildebrand, 1923). Elongate anchovy, anchoveta alargada. Addition to fauna.

Distribution: Atlantic slope: Tortuguero and Parismina. 0-5 m.

Remarks: This species has been reported in the Caribbean coast of Costa Rica by Bussing and López (2009; 2010). Ten specimens have been collected in freshwaters in the Colorado River (UCR 0990-19, n=1), the Tortuguero Lagoon (UCR 1768-01, n=2), the Jalova Lagoon (UCR 2665$04, n=4)$, Tortuguero drainage, and the Pacuare River (UCR 2837-05, n=3), Parismina drainage. Gilbert and Kelso (1971) collected thirty-nine specimens in freshwaters in the Tortuguero Lagoon, Tortuguero drainage.

\section{Genus: Lycengraulis Günther, 1868 (1).}

19. Lycengraulis grossidens (Agassiz, 1829). Atlantic sabretooth anchovy, anchoa dientona. Addition to fauna.

Distribution: Atlantic slope: Tortuguero. 0-3 m.

Remarks: This species has been reported in the Caribbean coast of Costa Rica by Bussing and López (2009; 2010). One specimen has been collected in freshwaters in the Tortuguero Lagoon (UCR 1788-10), Tortuguero drainage.

Order: Cypriniformes 1[2](2). 
Family: Cyprinidae [2](2). Primary.

\section{Genus: Carassius Nilsson, 1832 (1).}

20. Carassius auratus (Linnaeus, 1758)*. Goldfish, carpa dorada (23).

Distribution: Pacific slope: Tárcoles. 100-1779 m.

Remarks: Originally introduced from Asia, this species is found in Lake Fraijanes (Bussing 1998) and perhaps other ponds (Fowler 1932; Bussing 1998). We have not heard of specimens reaching other waters.

\section{Genus: Cyprinus Linnaeus, 1758 (1).}

21. Cyprinus carpio Linnaeus, 1758*. Common carp, carpa común. Addition to fauna.

Distribution: Pacific slope: Tárcoles. 112-1516 m.

Remarks: This species was introduced in 1976 from Taiwan in an attempt to strengthen aquaculture activities (Welcomme 1988). Two specimens have been collected in freshwaters in an unknown pond name in Alajuela (UCR 1104-01), Tárcoles drainage.

\section{Order: Characiformes $4[13](22)$.}

Family: Curimatidae [1](1). Primary.

\section{Genus: Cyphocharax Fowler, 1906 (1).}

22. Cyphocharax magdalenae (Steindachner, 1879). Carp headstander, capani (126).

Distribution: Pacific slope: Coto. 12-100 m.

Family: Erythrinidae [1](1). Primary.

\section{Genus: Hoplias Gill, 1903 (1).}

23. Hoplias microlepis (Günther, 1864). Tiger fish, pez perro (123).

Distribution: Pacific slope: Coto. 20-40 m.

Family: Lebiasinidae [1](1). Primary.

\section{Genus: Lebiasina Valenciennes, 1847 (1).}

24. Lebiasina boruca (Bussing, 1967). Candela (125).

Distribution: Pacific slope: Pirrís (A. Molina, pers. comm.), Térraba and Coto. 10-1000 m.

Remarks: This species was called Piabucina boruca in Bussing (1998). In the present account we recognize this species in the genus Lebiasina following Eigenmann and Allen (1942), Weitzman (1964), Dahl (1971), MachadoAllison (1974), Géry (1977), Taphorn (1992), ArdilaRodríguez (1994; 1999; 2000; 2001; 2002; 2004; 2008a, b; 2009; 2010) and Netto-Ferreira et al. (2011). This species is endemic to the Térraba and Coto drainages, Costa Rica (Bussing 1998).

Family: Characidae [10](19). Primary.

Genus: Astyanax Baird and Girard, 1854 (3).
25. Astyanax aeneus (Günther, 1860). Banded tetra, sardina (79).

Distribution: Atlantic slope: Lago de Nicaragua, Río Frío, San Juan, San Carlos, Sarapiquí, Tortuguero, Parismina, Matina and Sixaola. Pacific slope: Nicoya, Tempisque, Bebedero, Barranca, Tárcoles, Pirrís, Térraba and Coto. 0-1000 m.

26. Astyanax cocibolca Bussing 2008. Cocibolca tetra, sardina (85).

Distribution: Atlantic slope: Lago de Nicaragua, Río Frío, San Juan, San Carlos, Sarapiquí and Tortuguero. 5-20 $\mathrm{m}$.

Remarks: Bussing (2008) described A. cocibolca from specimens of the Lake Nicaragua and San Juan River that he previously considered as A. nasutus. This species is endemic to Lake Nicaragua and San Juan drainages (Bussing 2008).

27. Astyanax orthodus Eigenmann, 1907. Largespot tetra, sardina blanca (86).

Distribution: Atlantic slope: Sixaola. 1-60 m.

\section{Genus: Bramocharax Gill, 1877 (1).}

28. Bramocharax bransfordii Gill, 1877. Longjaw tetra, sardina picuda (88).

Distribution: Atlantic slope: Lago de Nicaragua, Río Frío, San Juan, San Carlos, Sarapiquí, Tortuguero and Parismina. 5-530 m.

Remarks: Rosen (1972) considered Bramocharax to be monophyletic and derived from some Astyanax species. On the other hand, Ornelas-García et al. (2008) proposed that this genus is not monophyletic and considered all Bramocharax species as morphotypes of Astyanax. The close relationship between Bramocharax and Astyanax proposed by Ornelas-García et al. (2008) was not supported by Mirande (2010), which instead relates Bramocharax with Oligosarcus Günther 1864. In the present account we provisionally keep this species in Bramocharax following Rosen (1972), Bussing (1998), Lima et al. (2003) and Mirande (2010); however, a comprehensive taxonomic study is needed to test the monophyly and position of this clade.

\section{Genus: Brycon Müller and Troschel, 1844 (2).}

29. Brycon behreae Hildebrand, 1938. Machaca del Pacífico (90).

Distribution: Pacific slope: Pirrís, Térraba and Coto. 10$640 \mathrm{~m}$.

30. Brycon costaricensis Angulo and Gracian-Negrete, 2013. Macabi tetra, machaca del Atlántico (93).

Distribution: Atlantic slope: Lago de Nicaragua, Río Frío, San Juan, San Carlos, Sarapiquí, Tortuguero, Parismina and Matina. 0-600 m.

Remarks: Angulo and Gracian-Negrete (2013) described B. costaricensis from specimens of the Atlantic slope of Nicaragua and Costa Rica that Bussing (1998) considered as B. guatemalensis. 


\section{Genus: Bryconamericus Eigenmann, 1907 (3).}

31. Bryconamericus gonzalezoi Román-Valencia 2002. Creek tetra, sardina de quebrada. Addition to fauna.

Distribution: Atlantic slope: Sixaola (STRI 0581). 69 m.

32. Bryconamericus scleroparius (Regan, 1908). Creek tetra, sardina de quebrada (97).

Distribution: Atlantic slope: Lago de Nicaragua, Río Frío, San Juan, San Carlos, Sarapiquí, Tortuguero, Parismina, Matina and Sixaola. Pacific slope: Tempisque. 12-600 m.

33. Bryconamericus terrabensis Meek, 1914. Creek tetra, sardina de quebrada (99).

Distribution: Pacific slope: Térraba. 60-940 m.

Remarks: This species is endemic to the Térraba drainage, Costa Rica (Bussing 1998; Román-Valencia 2002).

\section{Genus: Carlana Strand, 1928 (1).}

34. Carlana eigenmanni (Meek, 1912). Carlana tetra, sardinita (100).

Distribution: Atlantic slope: Lago de Nicaragua, Río Frío, San Juan, San Carlos, Sarapiquí, Tortuguero and Parismina. 35-90 m.

\section{Genus: Hyphessobrycon Durbin, 1908 (3).}

35. Hyphessobrycon panamensis Durbin, 1908. Panama tetra, sardinita (105).

Distribution: Atlantic slope: Sixaola. 40-60 m.

36. Hyphessobrycon savagei Bussing, 1967. Savage tetra, sardinita (108).

Distribution: Pacific slope: Pirrís and Térraba. 0-70 m.

Remarks: This species is endemic to the Pirrís and Térraba drainages, Costa Rica (Bussing 1998).

37. Hyphessobrycon tortuguerae Böhlke, 1958. Tortuguero tetra, sardinita de Tortuguero (110).

Distribution: Atlantic slope: Lago de Nicaragua, Río Frío, San Juan, San Carlos, Sarapiquí and Tortuguero. 0-50 $\mathrm{m}$.

\section{Genus: Odontostilbe Cope, 1870 (1).}

38. Odontostilbe dialeptura (Fink and Weitzman, 1974). Pygmy tetra, sardinita (103).

Distribution: Pacific slope: Coto. 20-90 m.

Remarks: This species was called Compsura dialeptura in Bussing (1998). In the present account we provisionally recognize this species in Odontostilbe following Malabarba and Weitzman (1999; 2000) and Malabarba (2003); however a new generic assignment is necessary for this species.

Genus: Pseudocheirodon Meek and Hildebrand, 1916 (1).

39. Pseudocheirodon Térrabae Bussing, 1967. Térraba tetra, sardinita (111).

Distribution: Pacific slope: Pirrís and Térraba. 0-680 m.
Remarks: This species is endemic to the Pirrís and Térraba drainages, Costa Rica (Bussing 1998).

\section{Genus: Pterobrycon Eigenmann, 1913 (1).}

40. Pterobrycon myrnae Bussing, 1974. Semaphore tetra, sardinita (113).

Distribution: Pacific slope: Pirrís and Térraba. 10-80 m.

Remarks: This species is endemic to the Pirrís and Térraba drainages, Costa Rica (Bussing 1998).

\section{Genus: Roeboides Günther, 1864 (3).}

41. Roeboides bouchellei Fowler, 1923. Glass headstander, sardina (116).

Distribution: Atlantic slope: Lago de Nicaragua, Río Frío, San Juan, San Carlos, Sarapiquí, Tortuguero, Parismina and Matina. Pacific slope: Nicoya, Tempisque, Bebedero and Barranca. 0-610 m.

42. Roeboides bussingi Matamoros, Chakrabarty, Angulo, Garita-Alvarado and McMahan, 2013. Glass headstander, sardina (117).

Distribution: Pacific slope: Coto. 11-118 m.

Remarks: Matamoros etal. (2013) described R. bussingi from specimens of the Pacific slope of Costa Rica and Panama that Bussing (1998) considered as R. sp.

43. Roeboides ilseae Bussing, 1986. Glass headstander, sardina (120).

Distribution: Pacific slope: Pirrís and Térraba. 10-660 m.

Remarks: This species is endemic to the Pirrís and Térraba drainages, Costa Rica (Bussing 1998).

\section{Order: Siluriformes 4[10](15).}

Family: Ariidae [3](6). Peripheral.

\section{Genus: Cathorops Jordan and Gilbert, 1883 (2).}

44. Cathorops steindachneri (Gilbert and Starks, 1904). Steindachner's sea catfish, congo boquita. Addition to fauna.

Distribution: Pacific slope: Tempisque and Térraba. 0-55 m.

Remarks: This species has been reported in the Pacific coast of Costa Rica by Bussing and López (1994, 2009). One specimen has been collected in freshwaters in the Tempisque River (UCR 2192-01), Tempisque drainage. Rojas and Rodríguez (2008) collected one specimen in freshwaters in the Grande de Térraba River, Térraba drainage.

45. Cathorops tuyra (Meek and Hildebrand, 1923). Besudo sea catfish, congo de río. Addition to fauna.

Distribution: Pacific slope: Tempisque and Térraba. 0-55 m.

Remarks: This species has been reported in the Pacific coast of Costa Rica by Bussing and López (1994; 2009; 2011). Two specimens have been collected in freshwaters in the Tempisque River (UCR 2265-01, UCR 2672-04), 
Tempisque drainage. Rojas and Rodríguez (2008) collected one specimen in freshwaters in the Grande de Térraba River, Térraba drainage.

\section{Genus: Notarius Gill, 1863 (1).}

46. Notarius cookei (Acero and Betancur-R, 2002). Sea catfish, bagre. Addition to fauna.

Distribution: Pacific slope: Tempisque. 0-6 m.

Remarks: This species has been reported in the Pacific coast of Costa Rica by Bussing and López (1994; 2009, both as Arius cookei). In the present account we recognize this species in the genus Notarius following Bentancur-R. and Acero (2004; 2006), Marceniuk and Menezes (2007) and Marceniuk et al. (2012). One specimen has been collected in freshwaters in the Tempisque River (UCR 2672-03), Tempisque drainage.

Genus: Sciades Müller and Troschel, 1849 (3). Costa Rican members of this genus were referred to the genus Arius by Bussing (1998) and Bussing and López (2009; 2010). In the present account we recognize these species in the genus Sciades following Marceniuk et al. (2012).

47. Sciades assimilis (Günther, 1864). Mayan sea catfish, bagre maya. Addition to fauna.

Distribution: Atlantic slope: Parismina. 0-7 m.

Remarks: This species has been reported in the Caribbean coast of Costa Rica by Bussing and López (2009; 2010). Three specimens have been collected in freshwaters in the Pacuare River (UCR 2836-07, $n=2$; UCR 2859-11, n=1), Parismina drainage.

48. Sciades guatemalensis (Günther, 1864). Blue sea catfish, bagre cuatete (138).

Distribution: Pacific slope: Tempisque. 0-11 m.

49. Sciades seemanni (Günther, 1864). Tete sea catfish, cuminate negro (139).

Distribution: Pacific slope: Nicoya, Tempisque, Bebedero (UCR 0152-07), Barranca (UCR 1268-26, UCR 1756-06, UCR 1793-01), Tárcoles (UCR 2194-01) and Térraba (UCR 2458-01). 0-32 m.

Family: Heptapteridae [3](5). Primary. Costa Rican members of this family were referred to the family Pimelodidade by Bussing (1998). In the present account we recognize these species in the family Heptapteridae following Bockmann and Guazzelli (2003) and Nelson (2006).

\section{Genus: Imparfinis Eigenmann and Norris, 1900 (1).}

50. Imparfinis lineatus (Bussing, 1970). Pigmy catfish, barbudito (144).

Distribution: Pacific slope: Térraba. 80-980 m.

Remarks: This species was called Nannorhamdia lineata in Bussing (1998). In the present account we recognize this species in the genus Imparfinis following Mees and Cala (1989), Burgess (1989), Bockmann and Guazzelli (2003), Ferraris (2007) and Ortega-Lara et al. (2011). This species is endemic to the Térraba drainage,
Costa Rica (Bussing 1998).

\section{Genus: Pimelodella Eigenmann and Eigenmann, 1888 (1).}

51. Pimelodella chagresi (Steindachner, 1876). Catfish, arrechito (145).

Distribution: Pacific slope: Térraba and Coto. 20-660 m.

\section{Genus: Rhamdia Bleeker, 1858 (3).}

52. Rhamdia guatemalensis (Günther, 1864). Catfish, barbudo (148).

Distribution: Atlantic slope: Lago de Nicaragua, Río Frío, San Juan, San Carlos, Sarapiquí, Tortuguero, Parismina, Matina and Sixaola. Pacific slope: Nicoya, Tempisque, Bebedero, Barranca, Tárcoles, Pirrís, Térraba and Coto. 0-680 m.

Remarks: Silfvergrip's (1996) revision of the genus synonymized $R$. guatemalensis with $R$. quelen. On the other hand, Perdices et al. (2002) analyzed the evolutionary history of the genus in Central America and concluded that Central American R. guatemalensis are evolutionarily distinct from $R$. quelen from South America. In the present account we recognize this species as valid and distinct from $R$. quelen following Bussing (1998), Weber and Wilkens (1998), Perdices et al. (2002), Weber et al. (2003), Sharpf (2006) and Matamoros et al. (2009).

53. Rhamdia laticauda (Kner, 1858). Filespine chulín, barbudo (154).

Distribution: Atlantic slope: Lago de Nicaragua, Río Frío, San Juan, San Carlos, Sarapiquí, Tortuguero, Parismina, Matina and Sixaola. Pacific slope: Tempisque, Bebedero, Barranca, Tárcoles, Pirrís, Térraba and Coto. 35-1350 m.

Remarks: This species was called Rhamdia rogersi (Regan, 1907) in Bussing (1998). In the present account we recognize this species as synonym of $R$. laticauda following Silfvergrip (1996), Bockmann and Guazzelli (2003), Ferraris (2007) and Matamoros et al. (2009).

54. Rhamdia nicaraguensis (Günther, 1864). Catfish, barbudo (152).

Distribution: Atlantic slope: Lago de Nicaragua, Río Frío, San Juan, San Carlos, Sarapiquí, Tortuguero and Parismina. Pacific slope: Tempisque, Bebedero, Barranca and Tárcoles. 20-1160 m.

Family: Trichomycteridae [1](1). Primary.

\section{Genus: Trichomycterus Valenciennes, 1832 (1).}

55. Trichomycterus striatus (Meek and Hidelbrand, 1913). Pencil catfish, laucha (159).

Distribution: Pacific slope: Térraba and Coto. 20-660 m.

Family: Loricariidae [3](3). Primary.

Genus: Fonchiiichthys Isbrücker and Michels, 2001 (1).

56. Fonchiiichthys uracanthus (Kner, 1863). Armored 
catfish, zapatero (162).

Distribution: Pacific slope: Coto. 20-160 m.

Remarks: This species was called Rineloricaria uracantha (Eigenmann, 1922) in Bussing (1998). In the present account we recognize this species in the genus Fonchiiichthys following Isbrücker (2001; 2002), FischMuller (2003) and Ferraris (2007).

\section{Genus: Hemiancistrus Bleeker, 1862 (1)}

57. Hemiancistrus aspidolepis (Günther, 1886). Panama suckermouth, arrisuaca (160).

Distribution: Atlantic slope: Río Frío (UCR 293301) and Parismina (Molina et al. 2010, as Hypostomus panamensis). Pacific slope: Térraba and Coto. 20-560 m.

Remarks: This species was called Hypostomus panamensis (Eigenmann, 1922) in Bussing (1998). In the present account we recognize this species in the genus Hemiancistrus as synonym of $H$. aspidolepis following Isbrücker (2001; 2002), Fisch-Muller (2003) and Ferraris (2007).

\section{Genus: Pterygoplichthys Gill, 1858 (1).}

58. Pterygoplichthys pardalis (Castelnau, 1855)*. Amazon sailfin catfish, pez diablo. Addition to fauna.

Distribution: Parismina. 20-110 m.

Remarks: One specimen has been collected in freshwaters in the Chanchera River (UCR 2911-01), Parismina drainage. Molina et al. (2010), as P. sp., and Herrera (2012) recorded this species in freshwaters in the Reventazón river, the Chanchera River and the Seis Amigos Lagoon, Parismina drainage. This species naturally occurs in Brazil and Peru, though it has been widely introduced to several countries around the world. In Costa Rica this species has been introduced most likely by aquarists (Molina et al. 2010; Herrera 2012).

\section{Order: Gymnotiformes 2[2](3).}

Family: Gymnotidae [1](2). Primary.

\section{Genus: Gymnotus Linnaeus, 1758 (2).}

59. Gymnotus cylindricus LaMonte, 1935. Knifefish, pez cuchillo (130).

Distribution: Atlantic slope: Lago de Nicaragua, Río Frío, San Juan, San Carlos, Sarapiquí, Tortuguero, Parismina, Matina and Sixaola. 1-50 m.

60. Gymnotus maculosus Albert and Miller, 1995. Knifefish, pez cuchillo (132).

Distribution: Atlantic slope: Lago de Nicaragua, Río Frío, San Juan, San Carlos, Sarapiquí and Tortuguero. Pacific slope: Nicoya, Tempisque and Bebedero. 20-540 m.

Family: Hypopomidae [1](1). Primary. Brachyhypopomus occidentalis (Regan, 1914), the unique species of this family know to be present in Costa Rica, was referred to the family Rhamphichthyidae by Bussing (1998). In the present account we recognize this species in Hypopomidae following Mago-Leccia (1994), Albert and
Campos-da-Paz (1998) and Albert (2001).

Genus: Brachyhypopomus Mago-Leccia, 1994 (1).

61. Brachyhypopomus occidentalis (Regan, 1914). Knifefish, pez cuchillo (134).

Distribution: Atlantic slope: Sixaola. 1-60 m.

Remarks: This species was called Hypopomus occidentalis in Bussing (1998). In the present account we recognize this species in the genus Brachyhypopomus following Mago-Leccia (1994) and Albert (2001).

\section{Order: Salmoniformes 1[1](1).}

Family: Salmonidae [1](1). Peripheral.

\section{Genus: Oncorhynchus Suckley, 1861 (1).}

62. Oncorhynchus mykiss (Walbaum, 1792). Rainbow trout, trucha arcoiris (22).

Distribution: Atlantic slope: Parismina (A. Molina, pers. comm.). Pacific slope: Pirrís (Vargas 2003, A. Molina, pers. comm.). 654-2202 m.

Remarks: This species was introduced in Costa Rica between 1927 and 1928 for private initiative to populate the Rivers lacking of native fish and promote the sport fishing (Bussing 1998; Vargas 2003).

\section{Order: Gobiesociformes 1[1](3).}

\section{Family: Gobiesocidae [1](3). Peripheral.}

\section{Genus: Gobiesox Lacepède, 1800 (3).}

63. Gobiesox fulvus Meek, 1907. Cocos stream clingfish, chupapiedra (250).

Distribution: Pacific slope: Isla del Coco. 0-304 m.

Remarks: This species is endemic to the Isla del Coco drainage, Costa Rica (Briggs 1955; Bussing 1998; Bussing and López 2005).

64. Gobiesox nudus (Linnaeus, 1758). Clingfish, chupapiedra (247).

Distribution: Atlantic slope: San Carlos, Sarapiquí, Tortuguero, Parismina, Matina and Sixaola. 25-580 m.

65. Gobiesox potamius Briggs, 1955. Clingfish, chupapiedra (249).

Distribution: Pacific slope: Nicoya, Tempisque, Bebedero, Barranca, Tárcoles, Pirrís and Térraba. 0-140 m.

Remarks: This species was thought to be endemic to the Nicoya, Tempisque, Bebedero, Barranca, Tárcoles, Pirrís and Térraba drainages, Costa Rica (Bussing 1998); however, McMahan et al. (2013) report this in El Salvador.

\section{Order: Atheriniformes 1[2](7).}

Family: Atherinopsidae [2](7). Peripheral. Costa Rican members of this family were referred to the family Atherinidae by Bussing (1998). In the present account we recognize these species in the family Atherinopsidae following Saeed et al. (1994), Dyer and Chernoff (1996) 
and Nelson (2006).

\section{Genus: Atherinella Steindachner, 1875 (6).}

66. Atherinella argentea Chernoff, 1986. Moon silverside, sardina (237).

Distribution: Pacific slope: Nicoya, Tempisque, Bebedero, Barranca, Tárcoles, Pirrís, Térraba and Coto. 0-7 m.

67. Atherinella blackburni (Schultz, 1949). Beach silverside, tinícalo playón. Adittion to fauna.

Distribution: Atlantic slope: Tortuguero. 0-3 m.

Remarks: This species has been reported in the Caribbean coast of Costa Rica by Bussing and López (2009; 2010). One specimen has been collected in freshwaters in the Tortuguero Lagoon (UCR 1788-10), Tortuguero drainage.

68. Atherinella chagresi (Meek and Hildebrand, 1914). Chagre's silverside, sardina (240).

Distribution: Atlantic slope: Tortuguero, Parismina, Matina and Sixaola. 8-60 m.

69. Atherinella hubbsi (Bussing, 1979). Silverside, sardina (241).

Distribution: Atlantic slope: Lago de Nicaragua, Río Frío, San Juan, San Carlos, Sarapiquí, Tortuguero, Parismina (UCR 1820-03) and Matina (UCR 1953-01). 35-540 m.

70. Atherinella milleri (Bussing, 1979). Miller's silverside, sardina (243).

Distribution: Atlantic slope: Lago de Nicaragua, Río Frío, San Juan, San Carlos, Sarapiquí, Tortuguero, Parismina, Matina and Sixaola. 0-40 m.

71. Atherinella sardina Meek, 1907. Silverside, sardina (244).

Distribution: Atlantic slope: Lago de Nicaragua. 0-40 m.

\section{Genus: Membras Bonaparte, 1836 (1).}

72. Membras gilberti (Jordan and Bollman, 1890). Landia silverside, pejerrey landia. Addition to fauna.

Distribution: Pacific slope: Barranca, Tárcoles, Pirrís and Térraba. 0-7 m.

Remarks: This species has been reported in the Pacific coast of Costa Rica by Bussing and López (1994; 2009; 2011). Twenty-nine specimens have been collected in freshwaters in the Lagarto River (UCR 1793-09, $\mathrm{n}=1$ ), Barranca drainage, the Drake River (UCR 0176-01, $n=4$ ) and the Rincón River (UCR 0456-05, n=24), Térraba drainage.

\section{Order: Cyprinodontiformes 3[12](33).}

\section{Family: Rivulidae [1](7). Secondary.}

Genus: Cynodonichthys Poey, 1860 (7). Costa Rican members of this genus were referred to the genus Rivulus by Bussing (1998). Costa (2011), based on molecular and morphological data of 33 rivuline taxa, restricted
Rivulus to two endemic species to Cuba and considered as valid genera Anablepsoides, Atlantirivulus, Laimosemion, Melanorivulus and Cynodonichthys, previously classified as subgenera of Rivulus. In the present account we placed in Cynodonichthys all Costa Rican rivulids species following this author.

73. Cynodonichthys fuscolineatus (Bussing, 1980). Arenal rivulus, olomina (171).

Distribution: Atlantic slope: San Carlos. Pacific slope: Bebedero. 525-695 m.

Remarks: This species is endemic to the San Carlos and Bebedero drainages, Costa Rica (Bussing 1980; 1998).

74. Cynodonichthys glaucus (Bussing, 1980). Blue rivulus, olomina (173).

Distribution: Pacific slope: Térraba and Coto. 540-680 m.

Remarks: This species is endemic to the Térraba and Coto drainages, Costa Rica (Bussing 1980; 1998).

75. Cynodonichthys hildebrandi (Myers, 1927). Speckled rivulus, olomina (175).

Distribution: Pacific slope: Térraba and Coto. 10-90 m.

76. Cynodonichthys isthmensis (Garman, 1985). Isthmian rivulus, olomina (176).

Distribution: Atlantic slope: Lago de Nicaragua, Río Frío, San Juan, San Carlos, Sarapiquí, Tortuguero, Parismina, Matina and Sixaola. Pacific slope: Bebedero and Tárcoles. 0-1500 m.

77. Cynodonichthys rubripunctatus (Bussing, 1980). Rivulus, olomina (177).

Distribution: Atlantic slope: Sixaola. 2-40 m.

Remarks: This species was recognized as a subspecies of $C$. isthmensis in Bussing (1980; 1998). In the present account we recognize this species as valid following Berkenkamp and Etzel (1999) and Costa (2003; 2006; 2011).

78. Cynodonichthys siegfriedi (Bussing, 1980). Rivulus, olomina (179).

Distribution: Pacific slope: Térraba. 20-80 m.

Remarks: This species was recognized as a subspecies of $C$. uroflammeus in Bussing $(1980 ; 1998)$. In the present account we recognize this species as valid following Costa (2003; 2006; 2011). This species is endemic to the Térraba drainage, Costa Rica (Bussing 1980).

79. Cynodonichthys uroflammeus (Bussing, 1980). Flame rivulus, olomina (179).

Distribution: Pacific slope: Térraba and Coto. 750-1100 m.

Family: Anablepidae [1](1). Secondary.

\section{Genus: Oxyzygonectes Fowler, 1916 (1).}

80. Oxyzygonectes dovii (Günther, 1866). White-eye, ojos blancos (166).

Distribution: Pacific slope: Nicoya, Tempisque, 
Bebedero, Barranca, Tárcoles, Pirrís, Térraba and Coto. 0-15 m.

\section{Family: Poeciliidae [10](25). Secondary.}

\section{Genus: Alfaro Meek, 1912 (1).}

81. Alfaro cultratus (Regan, 1908). Alfaro, olomina (192).

Distribution: Atlantic slope: Lago de Nicaragua, Río Frío, San Juan, San Carlos, Sarapiquí, Tortuguero, Parismina, Matina and Sixaola. Pacific slope: Tempisque. 0-300 m.

\section{Genus: Belonesox Kner, 1860 (1).}

82. Belonesox belizanus Kner, 1860. Pike killifish, gasparcillo (194).

Distribution: Atlantic slope: Lago de Nicaragua, Río Frío, San Juan, San Carlos, Sarapiquí, Tortuguero, Parismina and Matina. 0-45 m.

\section{Genus: Brachyrhaphis Regan, 1913 (6).}

83. Brachyrhaphis cascajalensis (Meek and Hildebrand, 1913). Olomina. Addition to fauna.

Distribution: Atlantic slope: Sixaola. 5-125 m.

Remarks: Bussing (1998) do not listed this species from Costa Rica, although he mentions that all specimens from the Sixaola drainage lack of a caudal black spot (apparently the unique feature present in B. cascajalensis that separate this of $B$. parismina). In the present account, following Meek and Hildebrand (1913), Rosen and Bailey (1963), Mojica et al. (1997), Parenti et al. (1999), Lucinda (2003) and Lucinda and Reis (2005) and on the basis of this feature, we recognize this species to be present in the Sixaola drainage; however, further studies are needed to clarify this situation as noted by Bussing (1998) and Meyer and Etzel (2001).

84. Brachyrhaphis holdridgei Bussing, 1967. Olomina (195).

Distribution: Atlantic slope: Lago Nicaragua, Rio Frío, San Juan, San Carlos, Sarapiquí, Tortuguero and Parismina. 35-620 m.

85. Brachyrhaphis olomina (Meek, 1914). Olomina (198).

Distribution: Atlantic slope: Lago de Nicaragua and Parismina. Pacific slope: Nicoya, Tempisque, Bebedero, Barranca and Tárcoles. 10-900 m.

Remarks: Rosen and Bailey (1963), Parenti et al. (1999) and Lucinda (2003) recognized B. olomina as synonym of B. rhabdophora (Regan 1908). Following Meek (1914), Bussing (1998) and Meyer and Etzel (1998) we recognize B. olomina as valid and different from B. rhabdophora, since the two species can be completely separated based on the number of gonopodial subterminal spines in ray $4 \mathrm{p}$ and the coloration pattern. This species is endemic to the Lago de Nicaragua, Parismina, Nicoya, Tempisque, Bebedero, Barranca and Tárcoles drainages, Costa Rica (Bussing 1998).
86. Brachyrhaphis parismina (Meek, 1912). Olomina (200)

Distribution: Atlantic slope: Lago de Nicaragua, Rio Frio, San Juan, San Carlos, Sarapiquí, Tortuguero, Parismina and Matina. 5-50 m.

87. Brachyrhaphis rhabdophora (Regan, 1908). Olomina (203)

Distribution: Pacific slope: Pirrís and Térraba. 3-1450 m (UCR 2432-02).

Remarks: This species is endemic to the Pirrís and Térraba drainages, Costa Rica (Bussing 1998).

88. Brachyrhaphis roseni Bussing, 1988. Olomina (205) Distribution: Pacific slope: Coto. 20-100 m.

89. Brachyrhaphis terrabensis (Regan, 1907). Olomina (207)

Distribution: Pacific slope: Pirrís (UCR 2934-01), Térraba and Coto. 40-1450 m (UCR 2934-01).

\section{Genus: Gambusia Poey, 1854 (1).}

90. Gambusia nicaraguensis Günther, 1866. Nicaraguan mosquitofish, olomina (209).

Distribution: Atlantic slope: Matina. 0-15 m.

\section{Genus: Phallichthys Hubbs, 1924 (3).}

91. Phallichthys amates (Miller, 1907). Merry widow, olomina (213).

Distribution: Atlantic slope: Lago de Nicaragua, Rio Frio, San Juan, San Carlos, Sarapiquí, Tortuguero, Parismina, Matina and Sixaola. Pacific slope: Tempisque, Bebedero and Tárcoles. 0-1120 m (UCR 0234-04).

92. Phallichthys quadripunctatus Bussing, 1979. Olomina (216).

Distribution: Atlantic slope: Sixaola. 0-40 m.

Remarks: This species is endemic to the Sixaola drainage, Costa Rica (Bussing 1998).

93. Phallichthys tico Bussing, 1963. Olomina (217).

Distribution: Atlantic slope: Lago de Nicaragua, San Juan, San Carlos and Sarapiquí. 35-600 m.

\section{Genus: Poecilia Bloch and Schneider, 1801 (4).}

94. Poecilia gillii (Kner and Steindachner, 1863). Molly, olomina/alumina panzona (219).

Distribution: Atlantic slope: Lago de Nicaragua, Río Frío, San Juan, San Carlos, Sarapiquí, Tortuguero, Parismina, Matina and Sixaola. Pacific slope: Nicoya, Tempisque, Bebedero, Barranca, Tárcoles, Pirrís and Térraba. 0-1220 $\mathrm{m}$.

95. Poecilia mexicana Steindachner, 1863. Shortfin molly, olomina (222).

Distribution: Atlantic slope: Lago de Nicaragua, Río Frío, San Juan, San Carlos, Sarapiquí, Tortuguero, Parismina and Matina. 2-45 m. 

(23).

96. Poecilia reticulata Peters, 1859*. Guppy, olomina

Distribution: Atlantic slope: Parismina (UCR 2541-02). Pacific slope: Tárcoles (UCR 0034-03, UCR 0084-01, UCR 0234-03). 30-1250 m.

Remarks: This species naturally occurs in Barbados, Trinidad, Venezuela, northern Brazil and the Guyanas, though it has been widely introduced to several countries around the world. In Costa Rica this species has been introduced most likely by aquarists (Bussing 1998; Devezé et al. 2004) and for hematophagous pests and diseasecarrying insect control (Lody 1978; Bussing 1998; Urriola et al. 2004).

\section{Genus: Poeciliopsis Regan, 1913 (5).}

97. Poeciliopsis elongata (Günther, 1866). Elongate toothcarp, olomina (223).

Distribution: Pacific slope: Nicoya, Tempisque, Bebedero, Barranca, Tárcoles, Pirrís, Térraba and Coto. 0-40 m.

(225).

98. Poeciliopsis paucimaculata Bussing, 1967. Olomina

Distribution: Pacific slope: Térraba and Coto. 20-940 m.

Remarks: This species is endemic to the Térraba and Coto drainages, Costa Rica (Bussing 1998).

99. Poeciliopsis retropinna (Regan, 1908). Olomina (227).

Distribution: Pacific slope: Térraba and Coto. 0-940 m.

100. Poeciliopsis santaelena Bussing, 2008. Olomina. Addition to fauna.

Distribution: Pacific slope: Nicoya (LACM 56479-001, $\mathrm{n}=10$; LACM 56480-001, $\mathrm{n}=1$; UCR 2507-02, $\mathrm{n}=3$; UCR 2508-01, n=6; UCR 2618-1, n=64; UCR 2696-01, n=41). 90-115 m.

Remarks: This species is endemic to the Potrero Grande River, Peninsula de Santa Elena, Nicoya drainage, Costa Rica (Bussing 2008). (229).

101. Poeciliopsis turrubarensis (Meek, 1912). Olomina

Distribution: Nicoya, Tempisque, Bebedero, Barranca, Tárcoles, Pirrís, Térraba and Coto. 0-120 m.

\section{Genus: Priapichthys Regan, 1913 (2).} (230)

102. Priapichthys annectens (Regan, 1907). Olomina

Distribution: Atlantic slope: Lago de Nicaragua, Río Frío, San Juan, San Carlos, Sarapiquí, Tortuguero, Parismina, Matina and Sixaola. Pacific slope: Nicoya, Tempisque, Bebedero, Barranca and Tárcoles. 25-1270 m.

Remarks: This species is endemic to the Lago de Nicaragua, Río Frío, San Juan, San Carlos, Sarapiquí, Tortuguero, Parismina, Matina, Sixaola, Nicoya, Tempisque, Bebedero, Barranca and Tárcoles drainages, Costa Rica (Bussing 1998).

103. Priapichthys panamensis Meek and Hildebrand,
1916. Olomina (232).

Distribution: Pacific slope: Nicoya, Tempisque, Bebedero, Barranca, Tárcoles, Pirrís, Térraba and Coto. 0-95 m (Rojas and Rodríguez 2008).

\section{Genus: Xenophallus Hubbs, 1924 (1).} (210)

104. Xenophallus umbratilis (Meek, 1912). Olomina

Distribution: Atlantic slope: Lago de Nicaragua, Río Frío, San Juan, San Carlos, Sarapiquí, Tortuguero and Parismina. Pacific slope: Bebedero. 35-590 m.

Remarks: This species was called Neoheterandria umbratilis in Bussing (1998). In the present account we recognize this species in the genus Xenophallus following Radda and Meyer (1981) and Lucinda and Reis (2005).

\section{Genus: Xiphophorus Heckel, 1848 (1).}

105. Xiphophorus variatus (Meek 1904)*. Variable platyfish, platí (23).

Distribution: Atlantic slope: Parismina. $45 \mathrm{~m}$.

Remarks: This species naturally occurs in Mexico, though it has been widely introduced to several countries around the world. In Costa Rica this species has been introduced most likely by aquarists (Bussing 1998).

\section{Order: Beloniformes 2[3](4).}

\section{Family: Belonidae [1](2). Peripheral.}

\section{Genus: Strongylura van Hasselt, 1824 (2).}

106. Strongylura marina (Walbaum, 1792). Atlantic needlefish, aguja verde. Addition to fauna.

Distribution: Atlantic slope: Tortuguero. 0-3 m.

Remarks: This species has been reported in the Caribbean coast of Costa Rica by Bussing and López (2009; 2010). Seven specimens have been collected in freshwaters in the Tortuguero Lagoon (UCR 1778-02, n=3; UCR 2495$21, n=4)$, Tortuguero drainage.

107. Strongylura timucu (Walbaum, 1792). Timucu, aguja timucú. Addition to fauna.

Distribution: Atlantic slope: Tortuguero and Matina. 0-13 m.

Remarks: This species has been reported in the Caribbean coast of Costa Rica by Bussing and López (2009; 2010). Five specimens have been collected in freshwaters in the Negro River (UCR 1296-02, n=4) and the Quebrada Westfalia River (UCR 0376-14, n=1), Matina drainage. Winemiller and Leslie (1992) recorded this species in freshwaters in the Tortuguero Lagoon, Tortuguero drainage.

Family: Hemiramphidae [2](2). Peripheral.

\section{Genus: Hemiramphus Cuvier, 1816 (1).}

108. Hemiramphus brasiliensis (Linnaeus, 1758). Ballyhoo halfbeak, agujeta brasileña. Addition to fauna.

Distribution: Atlantic slope: Tortuguero. 0-2 m. 
Remarks: This species has been reported in the Caribbean coast of Costa Rica by Bussing and López (2009; 2010). One specimen has been collected in freshwaters in the Colorado River (UCR 0990-08), Tortuguero drainage.

\section{Genus: Hyporhamphus Gill, 1859 (1).}

109. Hyporhamphus roberti (Valenciennes, 1847). Slender halfbeak, agujeta larga. Addition to fauna.

Distribution: Atlantic slope: Tortuguero. 0-2 m.

Remarks: This species has been reported in the Caribbean coast of Costa Rica by Bussing and López (2009; 2010). One specimen has been collected in freshwaters in the Colorado River (UCR 1067-11), Tortuguero drainage.

\section{Order: Syngnathiformes 1[3](5).}

Family: Syngnathidae [3](5). Peripheral.

\section{Genus: Microphis Kaup, 1853 (1).}

110. Microphis lineatus (Kaup, 1856). Opossum pipefish, pez pipa (256).

Distribution: Atlantic slope: Tortuguero (Gilbert and Kelso 1971; Winemiller and Leslie (1992), as Oostethus lineatus; UCR 1067-25, UCR 1072-01, UCR 1073-04, UCR 1882-02), Matina (LSUMZ 14776, LSUMZ 14787, UCR 0210-10, UCR 1127-03, UCR 1297-01, UCR 1352-09) and Sixaola (UCR 0281-13, UCR 1824-10, UCR 1838-02, UCR 1847-05). 0-12 m.

Remarks: This species was recognized as a subspecies of Oostethus brachyurus in Bussing (1998). In the present account we recognize this species as valid and place this in the genus Microphis following Ferraris (2003) and Kuiter (2009).

\section{Genus: Pseudophallus Herald, 1940 (3).}

111. Pseudophallus elcapitanensis (Meek and Hidelbrand, 1914). Pipefish, pez pipa (253).

Distribution: Pacific slope: Nicoya, Tempisque, Bebedero, Barranca, Tárcoles, Pirrís, Térraba and Coto. 0-20 m.

112. Pseudophallus mindi (Meek and Hidelbrand, 1923). Pipefish, pez pipa (255).

Distribution: Atlantic slope: Sarapiquí, Tortuguero, Parismina, Matina and Sixaola. 0-35 m.

113. Pseudophallus starksi (Jordan and Culver, 1895). Pipefish, pez pipa (257).

Distribution: Pacific slope: Nicoya, Tempisque, Bebedero, Barranca, Tárcoles, Pirrís, Térraba and Coto. 0-155 m.

\section{Genus: Syngnathus Linnaeus, 1758 (1).}

114. Syngnathus scovelli (Evermann and Kendall, 1896). Gulf pipefish, pez pipa del golfo. Addition to fauna.

Distribution: Atlantic slope: Tortuguero. 0-3 m.

Remarks: This species has been reported in the Caribbean coast of Costa Rica by Bussing and López (2009;
2010). One specimen has been collected in freshwaters in the Tortuguero Lagoon (UCR 1757-13), Tortuguero drainage.

\section{Order: Synbranchiformes 1[2](2).}

Family: Synbranchidae [2](2). Secondary.

Genus: Synbranchus Bloch, 1795 (1).

115. Synbranchus marmoratus Bloch, 1795. Marbled swamp eel, anguila de pantano (260).

Distribution: Atlantic slope: Lago de Nicaragua, Río Frío, San Juan, San Carlos, Sarapiquí, Tortuguero, Parismina, Matina and Sixaola. Pacific slope: Nicoya, Tempisque, Bebedero, Barranca, Tárcoles, Pirrís, Térraba and Coto. 0-640 m.

\section{Genus: Ophisternon McClelland, 1844 (1).}

116. Ophisternon aenigmaticum Rosen and Greenwood, 1976. Obscure swamp eel, anguila de pantano (259). Addition to fauna.

Distribution: Atlantic slope: Río Frío. 43 m.

Remarks: Rosen and Greenwood (1976) and Bussing (1998) suggested that 0 . aenigmaticum may occur in Costa Rica. Sáenz et al. (2006) collected six specimens in freshwaters in the Caño Negro National Wildlife Refuge, Río Frío drainage, confirming their occurrence in Costa Rica.

\section{Order: Perciformes 18[56](125).}

Family: Centropomidae [1](11). Peripheral.

\section{Genus: Centropomus Lacepède, 1802 (11).}

117. Centropomus armatus Gill, 1863. Armed snook, róbalo. Addition to fauna.

Distribution: Pacific slope: Barranca. 0-6 m.

Remarks: This species has been reported in the Pacific coast of Costa Rica by Bussing and López (1994; 2009; 2011). Six specimens have been collected in freshwaters in the Coyolito River (UCR 0962-05), Barranca drainage.

118. Centropomus ensiferus Poey, 1860. Swordspine snook, róbalo espolón. Addition to fauna.

Distribution: Atlantic slope: Tortuguero, Parismina, Matina and Sixaola. 0-11 m.

Remarks: This species has been reported in the Caribbean coast of Costa Rica by Bussing and López (2009; 2010). Four specimens have been collected in freshwaters in the Colorado River (UCR 0989-04, n=1), Caño Agua Fría Viejo River (UCR 1785-10, $n=1$ ), Tortuguero drainage, and Cocles River (UCR 2752-01, $n=2$ ), Matina drainage.

119. Centropomus medius Günther, 1864. Blackfin snook, gualaje aleta manchada (265).

Distribution: Pacific slope: Nicoya, Tempisque, Bebedero, Barranca, Tárcoles, Pirrís, Térraba and Coto. 0-250 m. 
120. Centropomus mexicanus Bocourt, 1868. Largescale fat snook, róbalo constantino. Addition to fauna.

Distribution: Atlantic slope: Tortuguero, Parismina, Matina and Sixaola. 0-4 m.

Remarks: This species has been reported in the Caribbean coast of Costa Rica by Bussing and López (2009; 2010). Four specimens have been collected in freshwaters in the Colorado River (UCR 1067-28, n=1; UCR 1073-05, $n=3)$, Tortuguero drainage.

121. Centropomus nigrescens Günther, 1864. Black snook, róbalo negro. Addition to fauna.

Distribution: Pacific slope: Nicoya, Tempisque, Bebedero, Barranca, Tárcoles, Pirrís, Térraba and Coto. 0-145 m.

Remarks: This species has been reported in the Pacific coast of Costa Rica by Bussing and López (1994, 2009). Sixty specimens have been collected in freshwaters in the Zelaya River (UCR 1487-02, n=2), Nicoya drainage, the Lagarto River (UCR 1268-23, n=1), the Pánica River (UCR 1488-11, n=9), Barranca drainage, the Quebrada Doña Maria River (UCR 1150-03, n=3), Tárcoles drainage, the Jicote River (UCR 3040-14, n=1), the Quebrada Aserradero River (UCR 3080-18, n=2), the Barú River (UCR 313008, n=20), Pirrís drainage, the Rincón River (UCR 016501, $\mathrm{n}=1$ ), the Riyito River (UCR 0690-10, $\mathrm{n}=3$ ), the Claro River (UCR 1941-01, n=15), the Pejeperro River (UCR 2534-03, n=1), the Pejeperrito Lagoon (UCR 2535-05, $\mathrm{n}=1$ ), Térraba drainage, and the Coto River (UCR 2181-01, $\mathrm{n}=1$ ), Coto drainage. Constantz et al. (1981), Winemiller (1983), Winemiller and Morales (1989) and Lyons and Schneider (1990) recorded this species in freshwaters in the Claro River, Térraba drainage. Rojas and Rodríguez (2008) collected sixty-four specimens in freshwaters in the Grande de Térraba River, Térraba drainage.

122. Centropomus parallelus Poey, 1860. Fat snook, calva (267).

Distribution: Atlantic slope: Río Frío, San Juan, San Carlos, Sarapiquí, Tortuguero, Parismina, Matina and Sixaola. 0-43 m.

123. Centropomus pectinatus Poey, 1860. Tarpon snook, róbalo sábalo (269).

Distribution: Atlantic slope: Tortuguero, Parismina, Matina and Sixaola. 0-12 m.

124. Centropomus robalito Jordan and Gilbert, 1882. Little snok, robalito (270).

Distribution: Pacific slope: Nicoya, Tempisque, Bebedero, Barranca, Tárcoles, Pirrís, Térraba and Coto. 0-50 m.

125. Centropomus undecimalis (Bloch, 1792). Common snok, robalo blanco (272).

Distribution: Atlantic slope: Tortuguero, Parismina, Matina and Sixaola. 0-50 m.

126. Centropomus viridis Lockington, 1877. White snok, robalo blanco. Addition to fauna.

Distribution: Pacific slope: Tempisque and Térraba. 0-145 m.
Remarks: This species has been reported in the Pacific coast of Costa Rica by Bussing and López (1994; 2009; 2011). One specimen has been collected in freshwaters in the Tempisque River (UCR 2188-01), Tempisque drainage. Rojas and Rodríguez (2008) collected sixty-four specimens in freshwaters in the Grande de Térraba River, Térraba drainage.

127. Centropomus unionensis Bocourt, 1868. Union snook, mano de piedra. Addition to fauna.

Distribution: Pacific slope: Tempisque and Pirrís (A. Molina, pers. comm.). 0-80 m (A. Molina, pers. comm.).

Remarks: This species has been reported in the Pacific coast of Costa Rica by Bussing and López (1994, 2009). Nine specimens have been collected in freshwaters in the Tempisque River (UCR 0970-01), Tempisque drainage.

Family: Serranidae [1](1). Peripheral.

Genus: Epinephelus Bloch, 1793 (1).

128. Epinephelus guttatus (Linnaeus, 1758). Red hind, cabrilla colorada. Addition to fauna.

Distribution: Atlantic slope: Tortuguero. 0-3 m.

Remarks: This species has been reported in the Caribbean coast of Costa Rica by Bussing and López (2009; 2010). One specimen has been collected in freshwaters in the Tortuguero Lagoon (UCR 0261-10), Tortuguero drainage.

\section{Family: Centrarchidae [1](1). Primary.}

\section{Genus: Micropterus Lacepède, 1802 (1).}

129. Micropterus salmoides (Lacepède, 1802). Largemouth black bass, black-bass (23).

Distribution: Pacific slope: Tárcoles (UCR 0074-07). $854 \mathrm{~m}$.

Remarks: This species was introduced in Costa Rica for private initiative to populate some artificial ponds to promote the sport fishing (Bussing 1998). We have not heard of specimens reaching other waters.

Family: Carangidae [4](9). Peripheral.

\section{Genus: Carangoides Bleeker, 1851 (1).}

134. Carangoides vinctus (Jordan and Gilbert, 1882). Cocinero, platanillo. Addition to fauna.

Distribution: Pacific slope: Tárcoles. 0-7 m.

Remarks: This species has been reported in the Pacific coast of Costa Rica by Bussing and López (1994, 2009, 2011 as Caranx vinctus). Alpírez (1985), as Caranx vinctus, recorded this species in freshwaters in the Quebrada Doña María River, Tárcoles drainage. In the present account, we recognize this species in the genus Carangoides following Castro-Aguirre et al. (1999) and Springer and Smith-Vaniz (2008).

\section{Genus: Caranx Lacepède, 1801 (4).}

130. Caranx caballus Günther, 1868. Green Jack, jurel. 
Addition to fauna.

Distribution: Pacific slope: Térraba. 0-55 m.

Remarks: This species has been reported in the Pacific coast of Costa Rica by Bussing and López (1994; 2005; 2009). Rojas and Rodríguez (2008) collected three specimens in freshwaters in the Grande de Térraba River, Térraba drainage.

131. Caranx caninus Günther, 1867. Pacific crevalle jack, jurel. Addition to fauna.

Distribution: Pacific slope: Tárcoles, Pirrís and Térraba. 0-55 m.

Remarks: This species has been reported in the Pacific coast of Costa Rica by Bussing and López (1994, 2005, 2009). Alpírez (1985) recorded this species in freshwaters in the Quebrada Doña María River, Tárcoles drainage, and the Paquita River, Pirrís drainage. Rojas and Rodríguez (2008) collected one specimen in freshwaters in the Grande de Térraba River, Térraba drainage.

132. Caranx hippos (Linnaeus, 1766). Crevalle jack, jurel. Addition to fauna.

Distribution: Atlantic slope: Tortuguero and Matina. 0-5 m.

Remarks: This species has been reported in the Caribbean coast of Costa Rica by Bussing and López (2009; 2010). Twenty-one specimens have been collected in freshwaters in the Colorado River (UCR 0989-07, $n=1$; UCR 0992-12, n=2; UCR 1073-08, n=2; UCR 1078-05, n=1), the Tortuguero Lagoon (UCR 0260-11, n=2; UCR 1790-10, $\mathrm{n}=1$ ), Tortuguero drainage, and the Quebrada Westfalia (UCR 0376-14, $\mathrm{n}=12$ ), Matina drainage.

133. Caranx latus Agassiz, 1831. Horse-eye jack, jurel (274).

Distribution: Atlantic slope: Tortuguero, Parismina, Matina and Sixaola. 0-20 m.

\section{Genus: Hemicaranx Bleeker, 1862 (1).}

135. Hemicaranx amblyrhynchus (Cuvier, 1833). Bluntnose jack, jurelito chato. Addition to fauna.

Distribution: Atlantic slope: Tortuguero. 0-3 m.

Remarks: This species has been reported in the Caribbean coast of Costa Rica by Bussing and López (2009; 2010). One specimen has been collected in freshwaters in the Colorado River (UCR 1067-23), Tortuguero drainage.

\section{Genus: Oligoplites Gill, 1863 (3).}

136. Oligoplites altus (Günther, 1868). Longjaw leatherjacket, cuero. Addition to fauna.

Distribution: Pacific slope: Térraba and Coto. 0-10 m.

Remarks: This species has been reported in the Pacific coast of Costa Rica by Bussing and López (1994; 2009; 2011). Six specimens have been collected in freshwaters in the Sierpe River (UCR 2863-04, n=5), Térraba drainage, and the Coto River (UCR 2181-03, n=1), Coto drainage.

137. Oligoplites palometa (Cuvier, 1831). Maracaibo letherjacket, pez cuero (276).

Distribution: Atlantic slope: Sarapiquí and Tortuguero.
0-10 m.

138. Oligoplites saurus (Bloch and Schneider, 1801). Leatherjacket, piña sietecueros. Addition to fauna.

Distribution: Atlantic slope: Tortuguero. 0-4 m.

Remarks: This species has been reported in the Pacific and Caribbean coasts of Costa Rica by Bussing and López (1994; 2009; 2010). Three specimens have been collected in freshwaters in the Tortuguero Lagoon (UCR 2495-14), Tortuguero drainage.

\section{Family: Lutjanidae [1](7). Peripheral.}

\section{Genus: Lutjanus Bloch, 1790 (7).}

139. Lutjanus analis (Cuvier, 1828). Mutton snapper, pargo criollo. Addition to fauna.

Distribution: Atlantic slope: Tortuguero and Matina. 0-3 m.

Remarks: This species has been reported in the Caribbean coast of Costa Rica by Bussing and López (2009; 2010). Four specimens have been collected in freshwaters in the Tortuguero Lagoon (UCR 0261-03, n=3), Tortuguero drainage, and the Suarez River (UCR 0779-07, n=1), Matina drainage.

140. Lutjanus argentiventris (Peters, 1869). Yellow snapper, pargo amarillo (278).

Distribution: Pacific slope: Nicoya, Tempisque, Bebedero, Barranca, Tárcoles, Pirrís, Térraba and Coto. 0-20 m.

141. Lutjanus colorado Jordan and Gilbert, 1882. Colorado snapper, pargo colorado. Addition to fauna.

Distribution: Pacific slope: Isla del Coco, Pirrís and Térraba. 0-17 m.

Remarks: This species has been reported in the Pacific coast of Costa Rica by Bussing and López (1994; 2005; 2009). Seven specimens have been collected in freshwaters in an unknown river name in the Cocos Island (LACM 35473-004, n=2), Isla del Coco drainage, the Quebrada Sucia River (UCR 1314-10, n=4), and the Pavo River (UCR 1868-02, n=1), Térraba drainage. Winemiller (1983), Winemiller and Morales (1989) and Lyons and Schneider (1990) recorded this species in freshwater in the Quebrada Camaronal River, the Pavo River and the Claro River, Térraba drainage. Alpírez (1985) recorded this species in freshwaters in the Paquita River, Pirrís drainage.

142. Lutjanus griseus (Linnaeus, 1758). Gray snapper, pargo mulato. Addition to fauna.

Distribution: Atlantic slope: Tortuguero. 0-3 m.

Remarks: This species has been reported in the Caribbean coast of Costa Rica by Bussing and López (2009; 2010). Two specimens have been collected in freshwaters in the Tortuguero Lagoon (UCR 2495-24), Tortuguero drainage.

143. Lutjanus jocu (Bloch and Schneider, 1801). Dog snapper, pargo caballera. Addition to fauna.

Distribution: Atlantic slope: Tortuguero, Parismina, Matina and Sixaola. 0-9 m. 
Remarks: This species has been reported in the Caribbean coast of Costa Rica by Bussing and López (2009; 2010). Ten specimens have been collected in freshwaters in the Caño Agua Fría River (UCR 1765-06, n=3; UCR 178507, $n=2$ ), the Caño California River (UCR 1808-09, $n=1$ ), Tortuguero drainage, the Pacuare River (UCR 2837-08, $\mathrm{n}=1$; UCR 2840-02, n=2), Parismina drainage, and the Urén River (UCR 1374-06, n=1), Sixaola drainage. Winemiller and Leslie (1992) recorded this species in freshwaters in the Tortuguero Lagoon, Tortuguero drainage.

144. Lutjanus jordani (Gilbert, 1898). Jordan's snapper, pargo ñanguero. Addition to fauna.

Distribution: Pacific slope: Térraba. 0-145 m.

Remarks: This species has been reported in the Pacific coast of Costa Rica by Bussing and López (1994; 2005; 2009). Rojas and Rodríguez (2008) collected three specimens in freshwaters in the Grande de Térraba River, Térraba drainage.

145. Lutjanus novemfasciatus Gill, 1862. Pacific dog snapper, pargo negro. Addition to fauna.

Distribution: Pacific slope: Tárcoles, Pirrís and Térraba. 0-95 m.

Remarks: This species has been reported in the Pacific coast of Costa Rica by Bussing and López (1994; 2005; 2009). Thirty-seven specimens have been collected in freshwaters in the Tárcoles River (UCR 0080-02, n=1), Tárcoles drainage, the Quebrada Aserradero River (UCR 0308-14, n=24), the Barú River (UCR 0313-09, n=2), Pirrís drainage, the Quebrada Sucia River (UCR 1314-06, n=5) and the Claro River (UCR 1869-03, n=1, UCR 1941-03, $\mathrm{n}=4$ ), Térraba drainage. Winemiller and Morales (1989) and Lyons and Schneider (1990) recorded this species in freshwaters in the Claro River, Térraba drainage. Rojas and Rodríguez (2008) collected one specimen in freshwaters in Grande de Térraba River, Térraba drainage.

\section{Family: Gerreidae [4](11). Peripheral.}

\section{Genus: Diapterus Ranzani, 1842 (3).}

146. Diapterus auratus Ranzani, 1842. Irish mojarra, mojarra gaucha. Addition to fauna.

Distribution: Atlantic slope: Tortuguero. 0-3 m.

Remarks: This species has been reported in the Caribbean coast of Costa Rica by Bussing and López (2009; 2010). Seven specimens have been collected in freshwaters in the Colorado River (UCR 0990-09, n=1), the Caño California River (UCR 1808-04, $\mathrm{n}=5$ ) and the Tortuguero Lagoon (UCR 2495-19, n=1), Tortuguero drainage.

147. Diapterus peruvianus (Cuvier, 1830). Peruvian mojarra, pargo blanco. Addition to fauna.

Distribution: Pacific slope: Barranca, Pirrís and Térraba. 0-10 m.

Remarks: This species has been reported in the Pacific coast of Costa Rica by Bussing and López (1994; 2009; 2011). Sixty-two specimens have been collected in freshwaters in the Lagarto River (UCR 0168-24, n=2), Barranca drainage, the Rincón River (UCR 0456-07, n=19), the Sirena River (UCR 1287-07, n=36) and the Sierpe River
(UCR 2863-03, n=5), Térraba drainage. Alpírez (1985) recorded this species in freshwaters in the Hatillo Nuevo River, Pirrís drainage.

148. Diapterus rhombeus (Cuvier, 1829). Caitipa mojarra, mojarra de estero. Addition to fauna.

Distribution: Atlantic slope: Tortuguero and Parismina. 0-12 m.

Remarks: This species has been reported in the Caribbean coast of Costa Rica by Bussing and López (2009; 2010). Five specimens have been collected in freshwaters in the Colorado River (UCR 0990-10; $n=1$, UCR 1070-06; $n=1$ ), the Gandoca River (UCR 1882-05; $n=2$ ), Tortuguero drainage, and the Pacuare River (UCR 2859-10; $n=1$ ), Parismina drainage.

\section{Genus: Eucinostomus Baird and Girard, 1855 (4).}

149. Eucinostomus argenteus Baird and Girard, 1855. Silver mojarra, mojarra plateada. Addition to fauna.

Distribution: Atlantic slope: Matina. 0-6 m.

Remarks: This species has been reported in the Caribbean coast of Costa Rica by Bussing and López (2009; 2010). Two specimens have been collected in freshwaters in the Suarez River (UCR 0209-15, n=1) and the Matina River (UCR 0804-10, n=1), Matina drainage.

150. Eucinostomus currani Zahuranec, 1980. Pacific flagfin mojarra, palmito bandera (286).

Distribution: Pacific slope: Nicoya, Tempisque, Bebedero, Barranca, Tárcoles, Pirrís, Térraba and Coto. 0-145 m (Rojas and Rodríguez 2008).

151. Eucinostomus dowii (Gill, 1863). Dow's mojarra, palmito plateado. Addition to fauna.

Distribution: Pacific slope: Pirrís. 0-10 m.

Remarks: This species has been reported in the Pacific coast of Costa Rica by Bussing and López (1994; 2009, both as E. argenteus). One specimen has been collected in freshwaters in the Barú River (UCR 0313-17), Pirrís drainage. In the present account we recognize this species as valid and distinct from E. argenteus following Allen and Robertson (1994), De la Cruz Agüero et al. (1997), Grove and Lavenberg (1997) and Castro-Aguirre et al. (1999).

152. Eucinostomus melanopterus (Bleeker, 1863). Flagfin mojarra, mojarra de ley. Addition to fauna.

Distribution: Atlantic slope: Tortuguero, Parismina and Matina. 0-10 m.

Remarks: This species has been reported in the Caribbean coast of Costa Rica by Bussing and López (2009; 2010). One hundred-eight specimens have been collected in freshwaters in the Colorado River (UCR 099011, $n=1$; UCR 1067-22, $n=32$; UCR 1070-09, $n=5$ ), the Caño California River (UCR 1808-07, n=1), the Tortuguero Lagoon (UCR 0260-07, n=1; UCR 1854-07, n=2; UCR 2495$18, \mathrm{n}=2$ ), Tortuguero drainage, the Suarez River (UCR 0209-09, n=32), the Quebrada Westfalia River (UCR 037611, n=20), the Negro River (UCR 1296-03, n=1), and the Hone Creek River (UCR 1352-11, n=11), Matina drainage.

Genus: Eugerres Jordan and Evermann, 1927 (2). 
153. Eugerres brevimanus (Günther, 1864). Short fin mojarra, pargo aleta corta (282).

Distribution: Pacific slope: Nicoya, Tempisque, Bebedero, Barranca, Tárcoles, Pirrís, Térraba and Coto. 0-145 m (Rojas and Rodríguez 2008).

154. Eugerres plumieri (Cuvier, 1830). Striped mojarra, mojarra prieta (285).

Distribution: Atlantic slope: San Juan, San Carlos, Sarapiquí and Tortuguero. 0-31 m.

\section{Genus: Gerres Quoy and Gaimard, 1824 (2).}

155. Gerres cinereus (Walbaum, 1792). Yellow fin mojarra, mojarra trompetera. Addition to fauna.

Distribution: Atlantic slope: Tortuguero. 0-12 m.

Remarks: This species has been reported in the Caribbean coast of Costa Rica by Bussing and López (2009; 2010). Two specimens have been collected in freshwaters in the Colorado River (UCR 1070-10, n=1) and the Gandoca River (UCR 1882-08, n=1), Tortuguero drainage.

156. Gerres simillimus Regan, 1907. Pacific yellow fin mojarra, palmito blanco. Addition to fauna.

Distribution: Pacific slope: Nicoya, Pirrís and Térraba. 0-640 m.

Remarks: This species has been reported in the Pacific coast of Costa Rica by Bussing and López $(1994 ; 2009$, both as $G$. cinereus). Seventeen specimens have been collected in freshwaters in the Quebrada Aserradero River (UCR 0308$21, \mathrm{n}=1$ ), Pirrís drainage, and an unknown river name in Isla del Caño (UCR 1849-06; n=16), Térraba drainage. Alpírez (1985), as G. cinereus, recorded this species in freshwaters in the Nosara River, Nicoya drainage, and the Pacuar River, Térraba drainage. In the present account we recognize this species as valid and distinct from $G$. cinereus following Regan (1907).

Family: Haemulidae [3](8). Peripheral.

\section{Genus: Conodon Cuvier, 1830 (1).}

157. Conodon nobilis (Linnaeus, 1758). Barred grunt, ronco canario. Addition to fauna.

Distribution: Atlantic slope: Tortuguero, Parismina, Matina and Sixaola. 0-51 m.

Remarks: This species has been reported in the Caribbean coast of Costa Rica by Bussing and López (2009; 2010). Seven specimens have been collected in freshwaters in the Tortuguero Lagoon (UCR 1788-09, n=6), Tortuguero drainage, and the Urén River (UCR 1374-05, n=1), Sixaola drainage.

\section{Genus: Haemulopsis Steindachner, 1869 (2).}

158. Haemulopsis corvinaeformis (Steindachner, 1868).

Roughneck grunt, corocoro gris. Addition to fauna.

Distribution: Atlantic slope: Tortuguero. 0-5 m.

Remarks: This species has been reported in the Caribbean coast of Costa Rica by Bussing and López (2009; 2010). Two specimens have been collected in freshwaters in the Tortuguero Lagoon (UCR 1788-08), Tortuguero drainage.

159. Haemulopsis leuciscus (Günther, 1864). Raucous grunt, vieja chinilla. Addition to fauna.

Distribution: Pacific slope: Térraba. 0-145 m.

Remarks: This species has been reported in the Pacific coast of Costa Rica by Bussing and López (1994; 2009; 2011). Rojas and Rodríguez (2008) collected three specimens in freshwaters in the Grande de Térraba River, Térraba drainage.

\section{Genus: Pomadasys Lacepède, 1802 (5).}

160. Pomadasys bayanus Jordan and Evermann, 1898. Purplemouth grunt, roncador (289).

Distribution: Pacific slope: Nicoya, Tempisque, Bebedero, Barranca, Tárcoles, Pirrís and Térraba. 0-640 m.

161. Pomadasys branickii (Steindachner, 1879). Sand grunt, burro. Addition to fauna.

Distribution: Pacific slope: Térraba. 0-17 m.

Remarks: This species has been reported in the Pacific coast of Costa Rica by Bussing and López (1994; 2009; 2011). Twenty specimens have been collected in freshwaters in the Rincón River (UCR 0456-04, n=15) and the Quebrada Sucia River (UCR 1314-09, n=5), Térraba drainage.

162. Pomadasys crocro (Cuvier, 1830). Burro grunt, roncador (291).

Distribution: Atlantic slope: Sarapiquí, Tortuguero, Parismina, Matina and Sixaola. 0-40 m.

163. Pomadasys empherus Bussing, 1993. Bigspine grunt, roncador. Addition to fauna.

Distribution: Pacific slope: Barranca. 0-10 m.

Remarks: This species has been reported in the Pacific coast of Costa Rica by Bussing and López (2009). One specimen has been collected in freshwaters in the Lagarto River (UCR 1690-12), Barranca drainage.

164. Pomadasys macracanthus (Günther, 1864). Longspine grunt, vieja espinalarga. Addition to fauna.

Distribution: Pacific slope: Barranca. 0-32 m.

Remarks: This species has been reported in the Pacific coast of Costa Rica by Bussing and López (1994; 2009; 2011). Three specimens have been collected in freshwaters in the Lagarto River (UCR 1268-25), Barranca drainage.

Family: Sciaenidae [5](5). Peripheral.

\section{Genus: Bairdiella Gill, 1861 (1).}

165. Bairdiella ronchus (Cuvier, 1830). Ground croaker, ronco rayado. Addition to fauna.

Distribution: Atlantic slope: Tortuguero. 0-5 m.

Remarks: This species has been reported in the Caribbean coast of Costa Rica by Bussing and López (2009; 2010). Three specimens have been collected in freshwaters in the Colorado River (UCR 1073-09, $\mathrm{n}=2$ ) and the Tortuguero Lagoon (UCR 1854-08, $\mathrm{n}=1$ ), Tortuguero drainage. Gilbert and Kelso (1971) collected 
three specimens in freshwaters in the Tortuguero Lagoon, Tortuguero drainage.

\section{Genus: Cynoscion Gill, 1861 (1).}

166. Cynoscion albus (Günther, 1864). Whitefin weakfish, corvina reina. Addition to fauna.

Distribution: Pacific slope: Bebedero. 0-6 m.

Remarks: This species has been reported in the Pacific coast of Costa Rica by Bussing and López (1994; 2009; 2011). Four specimens have been collected in freshwaters in the Bebedero River (UCR 1382-03), Bebedero drainage.

\section{Genus: Larimus Cuvier, 1830 (1).}

167. Larimus breviceps Cuvier, 1830. Shorthead drum, bombache cabezón. Addition to fauna.

Distribution: Atlantic slope: Tortuguero. 0-3 m.

Remarks: This species has been reported in the Caribbean coast of Costa Rica by Bussing and López (2009; 2010). One specimen has been collected in freshwaters in the Caño Agua Fría Viejo River (UCR 1785-08), Tortuguero drainage.

\section{Genus: Micropogonias Bonaparte, 1831 (1).}

168. Micropogonias furnieri (Desmarest, 1823). Whitemouth croaker, corvinón rayado. Addition to fauna.

Distribution: Atlantic slope: Tortuguero and Parismina. 0-3 m.

Remarks: This species has been reported in the Caribbean coast of Costa Rica by Bussing and López (2009; 2010). Six specimens have been collected in freshwaters in the Colorado River (UCR 0990-15, n=2; UCR 1067-12, $\mathrm{n}=2$ ), Tortuguero Lagoon (UCR 1854-08, n=1), Tortuguero drainage, and Pacuare River (UCR 2858-08, $n=1$ ), Parismina drainage.

\section{Genus: Ophioscion Gill, 1863 (1).}

169. Ophioscion typicus Gill, 1863. Point-nosed croaker, china corredora. Addition to fauna.

Distribution: Pacific slope: Térraba. 0-43 m.

Remarks: This species has been reported in the Pacific coast of Costa Rica by Bussing and López (1994; 2009; 2011). Two specimens have been collected in freshwaters in the Sierpe River (UCR 2310-02), Térraba drainage.

Family: Polynemidae [1](1). Peripheral.

\section{Genus: Polydactylus Lacepède, 1803 (1).}

170. Polydactylus virginicus (Linnaeus, 1758). Barbu, barbudo barbú. Addition to fauna.

Distribution: Atlantic slope: Tortuguero, Parismina and Matina. 0-6 m.

Remarks: This species has been reported in the Caribbean coast of Costa Rica by Bussing and López (2009; 2010). Twenty-five specimens have been collected in freshwaters in the Tortuguero Lagoon (UCR 1788-06, $\mathrm{n}=4$; UCR 2495-20, n=11; UCR 2804-06, n=1), Tortuguero drainage, the Pacuare River (UCR 2859-08, n=8), Parismina drainage, and the Suarez River (UCR 0209-06, n=1), Matina drainage.

Family: Kyphosidae [1](1). Peripheral.

\section{Genus: Kyphosus Lacepède, 1801 (1).}

171. Kyphosus sectatrix (Linnaeus, 1758). Bermuda sea chub, chopa blanca. Addition to fauna.

Distribution: Atlantic slope: Tortuguero. 0-3 m.

Remarks: This species has been reported in the Caribbean coast of Costa Rica by Bussing and López (2009; 2010). One specimen has been collected in freshwaters in the Tortuguero Lagoon (UCR 2495-20), Tortuguero drainage.

Family: Mugilidae [3](4). Peripheral.

\section{Genus: Agonostomus Bennett, 1832 (1).}

172. Agonostomus monticola (Bancroft, 1834). Mountain mullet, tepemechín (385).

Distribution: Atlantic slope: Lago de Nicaragua, Río Frío, San Juan, San Carlos, Sarapiquí, Tortuguero, Parismina, Matina and Sixaola. Pacific slope: Isla del Coco, Nicoya, Tempisque, Bebedero, Barranca, Tárcoles, Pirrís, Térraba and Coto. 0-650 m.

\section{Genus: Joturus Poey, 1860 (1).}

173. Joturus pichardi Poey, 1860. Bobo mullet, bobo (390).

Distribution: Atlantic slope: Sarapiquí, Tortuguero, Parismina, Matina and Sixaola. 0-600 m.

Genus: Mugil Linnaeus, 1758 (2).

174. Mugil cephalus Linnaeus, 1758. Flathead grey mullet, liza rayada. Addition to fauna.

Distribution: Atlantic slope: Tortuguero. 0-3 m.

Remarks: This species has been reported in the Pacific and Caribbean coasts of Costa Rica by Bussing and López (2009; 2010). Two specimens have been collected in freshwaters in the Colorado River (UCR 0990-12), Tortuguero drainage.

175. Mugil curema Valenciennes, 1836. White mullet, lisa blanca. Addition to fauna.

Distribution: Atlantic slope: Tortuguero, Parismina, Matina and Sixaola. Pacific slope: Nicoya, Tempisque, Bebedero, Barranca, Tárcoles, Pirrís, Térraba and Coto. 0-145 m.

Remarks: This species has been reported in the Pacific and Caribbean coasts of Costa Rica by Bussing and López (1994; 2009; 2010). Three hundred eightyseven specimens have been collected in freshwaters in the Colorado River (UCR 1067-09, n=10), Tortuguero drainage, the Quebrada Westfalia River (UCR 0376-04, $n=12$ ), Matina drainage, an unknown river name in Gandoca (UCR 2011-02, n=38), Sixaola drainage, the Calera River (UCR 0935-07, $n=205$ ), Nicoya drainage, the Lagarto River (UCR 1268-05, n=2, UCR 1803-03, n=1), Barranca drainage, 
the Quebrada Aserradero River (UCR 0308-19, n=3), the Tusubres River (UCR 1368-08, n=3), Pirrís drainage, the Quebrada sucia River (UCR 1314-08, n=6), an unknown river name in Isla del Caño (UCR 1791-02, $n=5$; UCR 1849-02, n=34), the Bravo River (UCR 1867-01, $n=1$ ), the Sirena River (UCR 1872-04, n=6), the Sierpe River (UCR 2863-02, n=4), Térraba drainage, and the Quebrada Pavita River (UCR 1316-04, n=57), Coto drainage. Winemiller (1983), Winemiller and Morales (1989) and Lyons and Schneider (1990) recorded this species in freshwaters in the Quebrada Camaronal River, the Pavo River and the Claro River, Térraba drainage. Alpírez (1985) recorded this species in freshwaters in the Guacimal River, Barranca drainage and the Punta Mala River, Térraba drainage. Rojas and Rodríguez (2008) collected two specimens in freshwaters in the Grande de Térraba River, Térraba drainage.

\section{Family: Cichlidae [10](26). Secondary.}

Genus: Amatitlania Schmitter-Soto, 2007 (2). Schmitter-Soto (2007a) described A. kanna, from Atlantic slope of Costa Rica and Panama, and A. siquia, from Honduras, Nicaragua and Costa Rica, from specimens that Bussing (1998) considered as Archocentrus nigrofasciatus (Günther, 1867).

176. Amatitlania kanna Schmitter-Soto 2007. Convict cichlid, mojarra (342, in part).

Distribution: Atlantic slope: Sixaola. 0-65 m.

177. Amatitlania siquia Schmitter-Soto 2007. Convict cichlid, mojarra (342, in part).

Distribution: Atlantic slope: Lago de Nicaragua, Río Frío, San Juan, San Carlos, Sarapiquí, Tortuguero, Parismina and Matina; Pacific slope: Nicoya, Tempisque, Bebedero, Barranca and Tárcoles. 0-540 m.

Genus: Amphilophus Agassiz, 1859 (9). Costa Rican members of this genus, with exception of $A$. citrinellus and A. lyonsi, were referred to the genus Astatheros by Bussing (1998). In the present account we provisionally recognize in the genus Amphilophus all Costa Rican Astatheros species (sensu Bussing 1998) following Loiselle (1997), Kullander and Hartel (1997), Burgess (2000) and Kullander (2003); however a comprensive taxomonic work is needed to test the monophyly and position of this group.

178. Amphilophus alfari (Meek, 1907). Pastel cichlid, mojarra (318).

Distribution: Atlantic slope: Lago de Nicaragua, Río Frío, San Juan, San Carlos, Sarapiquí, Tortuguero, Parismina and Matina; Pacific slope: Nicoya, Tempisque, Bebedero and Tárcoles. 2-1150 m.

179. Amphilophus altifrons (Kner, 1863). Mojarra (322). Distribution: Pacific slope: Coto. 20-400 m.

180. Amphilophus bussingi Loiselle, 1997. Mojarra (324).

Distribution: Atlantic slope: Sixaola. 40-150 m.

Remarks: This species is endemic to the Sixaola drainage, Costa Rica (Bussing 1998).

181. Amphilophus citrinellus (Günther, 1864). Midas cichlid, mojarra (312).

Distribution: Atlantic slope: Lago de Nicaragua, Río Frío, San Juan, San Carlos, Sarapiquí, Tortuguero, Parismina and Matina. 0-12 m.

182. Amphilophus diquis (Bussing, 1974). Mojarra (327).

Distribution: Pacific slope: Pirrís, Térraba and Coto. 16$700 \mathrm{~m}$.

Remarks: This species is endemic to the Pirrís, Térraba and Coto drainages, Costa Rica (Bussing 1998).

183. Amphilophus longimanus (Günther, 1867). Red breast cichlid, cholesca (329).

Distribution: Atlantic slope: Lago de Nicaragua, Río Frío, San Juan, San Carlos, Sarapiquí, Tortuguero. Pacific slope: Nicoya, Tempisque and Bebedero. 0-100 m.

184. Amphilophus lyonsi (Gosse, 1966). Mojarra (316). Distribution: Pacific slope: Coto. 10-20 m.

185. Amphilophus rhytisma (López S., 1983). Pearl cichlid, mojarra (332).

Distribution: Atlantic slope: Sixaola. 40-60 m.

186. Amphilophus rostratus (Gill, 1877). Masamiche (334).

Distribution: Atlantic slope: Lago de Nicaragua, Río Frío, San Juan, San Carlos, Sarapiquí, Tortuguero, Parismina and Matina. 0-200 m.

Genus: Andinoacara Musilová, Říĉan and Novák, 2009 (1).

187. Andinoacara coeruleopunctatus (Kner, 1863). Mojarra (310).

Distribution: Pacific slope: Coto. 20-100 m.

Remarks: This species was called Aequides coeruleopunctatus in Bussing (1998). In the present account we recognize this species in the genus Andinoacara following Musilova et al. (2009).

\section{Genus: Archocentrus Gill, 1877 (2).}

188. Archocentrus centrarchus (Gill, 1877). Flier cichlid, mojarra rayada (336).

Distribution: Atlantic slope: Lago de Nicaragua, Río Frío, San Juan, San Carlos, Sarapiquí, Tortuguero, Parismina and Matina. 0-45 m.

189. Archocentrus multispinosus (Günther, 1867). Rainbow cichlid, mojarrita (351).

Distribution: Atlantic slope: Lago de Nicaragua, Río Frío, San Juan, San Carlos, Sarapiquí, Tortuguero, Parismina and Matina. Pacific slope: Nicoya, Tempisque and Bebedero. 0-75 m.

Remarks: This species was called Herotilapia multispinosa in Bussing (1998). In the present account we recognize this species in the genus Archocentrus following 
Schmitter-Soto (2007a, b).

Genus: Cryptoheros Allgayer, 2001 (3). Costa Rican members of this genus were referred to the genus Archocentrus by Bussing (1998). In the present account we recognize this species in the genus Cryptoheros following Allgayer (2001) and Schmitter-Soto (2007a, b).

190. Cryptoheros myrnae (Loiselle, 1997). Topaz cichlid, mojarra (340).

Distribution: Atlantic slope: Sixaola. 40-150 m.

Remarks: This species is endemic to the Sixaola drainage, Costa Rica (Bussing 1998).

191. Cryptoheros sajica (Bussing, 1974). T-Bar cichlid, mojarra (346).

Distribution: Pacific slope: Pirrís, Térraba and Coto. 10$680 \mathrm{~m}$.

Remarks: This species is endemic to the Pirrís, Térraba and Coto drainages, Costa Rica (Bussing 1998).

192. Cryptoheros septemfasciatus (Regan, 1908). Mojarra (348).

Distribution: Atlantic slope: Lago de Nicaragua, Río Frío, San Juan, San Carlos, Sarapiquí, Tortuguero, Parismina and Matina. 12-600 m.

\section{Genus: Hypsophrys Agassiz, 1859 (2).}

193. Hypsophrys nematopus (Günther, 1867). Poor man's tropheus, moga (357).

Distribution: Atlantic slope: Lago de Nicaragua, Río Frío, San Juan, San Carlos, Sarapiquí and Tortuguero. Pacific slope: Bebedero (UCR 2935-01). 35-535 m.

Remarks: This species was called Neetroplus nematopus in Bussing (1998). In the present account we recognize this species in the genus Hypsophrys following Chakrabarty and Sparks (2007) and Schmitter-Soto (2007a, b).

194. Hypsophrys nicaraguensis (Günther, 1864). Butterfly cichlid, moga amarilla (354).

Distribution: Atlantic slope: Lago de Nicaragua, Río Frío, San Juan, San Carlos, Sarapiquí, Tortuguero, Parismina and Matina. Pacific slope: Bebedero (UCR 2935-02). 5-200 m.

\section{Genus: Oreochromis Günther, 1889 (1).}

195. Oreochromis niloticus (Linnaeus, 1758)*. Tilapia. Addition to fauna.

Distribution: Atlantic slope: Río Frío, San Juan (C. Garita and A. Angulo, pers. comm.), San Carlos, Sarapiquí (C. Garita, A. Angulo and B. Naranjo, pers. comm.), Tortuguero, Parismina (A. Molina, pers. comm.), Matina (A. Angulo, pers. comm.) and Sixaola (A. Angulo, pers. comm.). Pacific slope: Nicoya (A. Angulo, pers. comm.), Bebedero, Tárcoles and Térraba. 0-1250 m.

Remarks: Eight specimens have been collected in freshwaters in the Arenal Lake (UCR 1989-01, n=3), the Aguacate River (UCR 2015-01, n=2), San Carlos drainage, and an unknown pond name in Alajuela (UCR 1043-04, $\mathrm{n}=3$ ), Tárcoles drainage. Cabrera et al. (1993) and Sáenz et al. (2006) recorded this species in freshwaters in the Caño
Negro National Wildlife Refuge, Río Frío drainage. Oro and Cabrera (1993) recorded this species in freshwaters in the Colorado River, Tortuguero drainage. Pizarro and Rojas (1993) recorded this species in freshwaters in the Bebedero River, Bebedero drainage. Rojas and Rodríguez (2008) collected twenty-two specimens in freshwaters in the Grande de Térraba River, Térraba drainage. This species was introduced in 1963 from El Salvador by government agencies in an attempt to strengthen aquaculture activities (Ruíz 1978).

\section{Genus: Parachromis Agassiz, 1859 (3).}

196. Parachromis dovii (Günther, 1864). Guapote, guapote azul/lagunero (360).

Distribution: Atlantic slope: Lago de Nicaragua, Río Frío, San Juan, San Carlos, Sarapiquí, Tortuguero, Parismina and Matina; Pacific slope: Nicoya, Tempisque and Bebedero. 0-600 m.

197. Parachromis loisellei (Bussing, 1989). Guapotito, viejito (364).

Distribution: Atlantic slope: Lago de Nicaragua, Río Frío, San Juan, San Carlos, Sarapiquí, Tortuguero, Parismina, Matina and Sixaola. Pacific slope: Bebedero and Térraba. 1-70 m.

198. Parachromis managuensis (Günther, 1867). Jaguar guapote, guapote tigre (367).

Distribution: Atlantic slope: Lago de Nicaragua, Río Frío, San Juan, San Carlos, Sarapiquí, Tortuguero, Parismina, Matina and Sixaola. Pacific slope: Bebedero (Werner 1983). 0-45 m.

Genus: Tomocichla Regan, 1908 (2). Costa Rican members of this genus were referred to the genus Theraps by Bussing (1998). In the present account we provisionally recognize this species in the genus Tomocichla following Burgues (2000), Allgayer (2002), Kullander (2003) and Chakrabarty (2007); however a comprensive taxomonic work is needed to test the monophyly and position of this clade.

199. Tomocichla sieboldii (Kner, 1863). Moga (372).

Distribution: Pacific slope: Tárcoles, Pirrís, Térraba and Coto. $10-840 \mathrm{~m}$.

200. Tomocichla tuba (Meek, 1912). Vieja, tuba (376).

Distribution: Atlantic slope: Lago de Nicaragua, Río Frío, San Juan, San Carlos, Sarapiquí, Tortuguero, Parismina, Matina and Sixaola. 0-540 m.

Remarks: This species was called Theraps underwoodi in Bussing (1998). In the present account we recognize this species as synonym of Tomocichla tuba following Burgues (2000), Allgayer (2002), Kullander (2003) and Chakrabarty (2007).

\section{Genus: Vieja Fernández-Yépez, 1969 (1).}

201. Vieja maculicauda (Regan, 1905). Blackbelt cichlid, vieja (380).

Distribution: Atlantic slope: Tortuguero, Parismina, 
Matina and Sixaola. 0-5 m.

Remarks: McMahan et al. (2010) sugested the genus Paraneetroplus for this species based on a molecular phylogeny; however, we provisionally keep this species on Vieja until a comprensive morphological diagnosis for the proposed clades are made.

\section{Family: Labridae [1](2). Peripheral.}

\section{Genus: Halichoeres Rüppell, 1835 (2).}

202. Halichoeres aestuaricola Bussing, 1972. Mangrove wrasse, señorita de manglar. Addition to fauna.

Distribution: Pacific slope: Pirrís and Térraba. 0-17 m.

Remarks: This species has been reported in the Pacific coast of Costa Rica by Bussing and López (2009). Two specimens have been collected in freshwaters in the Quebrada Aserradero River (UCR 0318-17, n=1), Pirrís drainage, and the Quebrada Sucia River (UCR 1314-12, $n=1)$, Térraba drainage.

203. Halichoeres notospilus (Günther, 1864). Banded wrasse, señorita listada. Addition to fauna.

Distribution: Pacific slope: Térraba. 0-15 m.

Remarks: This species has been reported in the Pacific coast of Costa Rica by Bussing and López (2005; 2009). Alpírez (1985) recorded this species in freshwaters in the Punta Mala River, Térraba drainage.

Family: Dactyloscopidae [1](1). Peripheral.

\section{Genus: Dactyloscopus Gill, 1859 (1).}

204. Dactyloscopus amnis Miller and Briggs, 1962. Riverine stargazer, Miraestrellas ribereña. Addition to fauna.

Distribution: Pacific slope: Barranca and Pirrís. 0-10 m.

Remarks: This species has been reported in the Pacific coast of Costa Rica by Bussing and López (2009). Thirtythree specimens have been collected in freshwaters in the Lagarto River (UCR 1756-03, n=1), Barranca drainage, and the Quebrada Aserradero River (UCR 0308-07, n=32), Pirrís drainage.

Family: Blenniidae [1](1). Peripheral.

\section{Genus: Hypsoblennius Gill, 1861 (1).}

205. Hypsoblennius maculipinna (Regan, 1903). Finspot blenny, cachudito aleta manchada. Addition to fauna.

Distribution: Pacific slope: Pirrís. 0-10 m.

Remarks: This species has been reported in the Pacific coast of Costa Rica by Bussing and López (1994; 2009; 2011). Two specimens have been collected in freshwaters in the Quebrada Aserradero River (UCR 0308-16), Pirrís drainage.

Family: Eleotridae [7](16). Peripheral.

\section{Genus: Dormitator Gill, 1861 (2).}

206. Dormitator latifrons (Richardson, 1844). Pacific fat sleeper, pocoyo (410).

Distribution: Pacific slope: Nicoya, Tempisque, Bebedero, Barranca, Tárcoles, Pirrís, Térraba and Coto. 0-145 m (Rojas and Rodríguez 2008).

207. Dormitator maculatus (Bloch, 1792). Fat sleeper, guarasapa (411):

Distribution: Atlantic slope: Tortuguero, Parismina, Matina and Sixaola. 0-12 m.

\section{Genus: Eleotris Bloch and Schneider, 1801 (5).}

208. Eleotris amblyopsis (Cope, 1871). Large-scaled spinycheek sleeper, pez perro (413).

Distribution: Atlantic slope: Tortuguero, Parismina, Matina and Sixaola. 0-15 m.

(416)

209. Eleotris picta Kner, 1863. Spotted sleeper, vieja

Distribution: Pacific slope: Isla del Coco (Bussing and López 2005; LACM 26462, UCR 0736-05, UCR 2275-02), Nicoya, Tempisque, Bebedero, Barranca, Tárcoles, Pirrís, Térraba and Coto. 0-100 m.

210. Eleotris pisonis (Gmelin, 1789). Spinycheek sleeper, pez perro (417).

Distribution: Atlantic slope: Tortuguero, Parismina, Matina and Sixaola. 0-60 m.

211. Eleotris tecta Bussing, 1996. Sleeper, pez perro (418).

Distribution: Pacific slope: Térraba and Coto. 0-75 m.

212. Eleotris tubularis Heller and Snodgrass, 1903. Cocos sleeper, vieja de Cocos. Addition to fauna.

Distribution: Pacific slope: Isla del Coco. 0-53 m.

Remarks: This species has been reported in the saltwaters of the Cocos Island National Park, Costa Rica by Bussing and López (2005). Twenty-five specimens have been collected in freshwaters in an unknown river name in the Chatam Bay (LACM 25806, n=23; UCR 0736-03, n=2), Isla del Coco drainage. This species is endemic to the Isla del Coco drainage, Costa Rica (Bussing 1996; Pezold and Cage 2002; Bussing and López 2005; Van Tassell 2011).

\section{Genus: Erotelis Poey, 1860 (1).}

213. Erotelis armiger (Jordan and Richardson, 1895). Flathead sleeper, Guavina cabeza plana. Addition to fauna.

Distribution: Pacific slope: Pirrís. 0-10 m.

Remarks: This species has been reported in the Pacific coast of Costa Rica by Bussing and López (2009). Fiftyfour specimens have been collected in freshwaters in the Barú River (UCR 0308-04, n=8, UCR 0313-12, n=46), Pirrís drainage. Winemiller (1983) recorded this species in freshwaters in the Quebrada Camaronal River, Térraba drainage.

\section{Genus: Gobiomorus Lacepède, 1800 (3).}

214. Gobiomorus dormitor Lacepède, 1800. Bigmouth sleeper, guavina (420). 
Distribution: Atlantic slope: Lago de Nicaragua, Río Frío, San Juan, San Carlos, Sarapiquí, Tortuguero, Parismina, Matina and Sixaola. 0-60 m.

215. Gobiomorus maculatus (Günther, 1859). Pacific sleeper, guavina (422).

Distribution: Pacific slope: Nicoya, Tempisque, Bebedero, Barranca, Tárcoles, Pirrís, Térraba and Coto. 0-145 m (Rojas and Rodríguez 2008).

216. Gobiomorus polylepis Ginsburg, 1953. Finescale sleeper, guavina (424).

Distribution: Pacific slope: Nicoya. 2-15 m.

\section{Genus: Guavina Bleeker, 1874 (2).}

217. Guavina guavina (Valenciennes, 1837). Guavina, guavina. Addition to fauna.

Distribution: Atlantic slope: Sixaola. 0-10 m.

Remarks: This species has been reported in the Caribbean coast of Costa Rica by Bussing and López (2009; 2010). Two specimens have been collected in freshwaters in the Sixaola River (UCR 0280-03), Sixaola drainage.

218. Guavina micropus Ginsburg, 1953. Guavina, guavina. Addition to fauna.

Distribution: Pacific slope: Térraba. 0-2 m.

Remarks: Three specimens have been collected in freshwaters in the Esquinas River (UCR 1312-04), Térraba drainage. (1).

\section{Genus: Hemieleotris Meek and Hildebrand, 1916}

219. Hemieleotris latifasciata (Meek and Hidebrand, 1912). Pygmy sleeper, guavinita (425).

Distribution: Pacific slope: Nicoya, Tempisque, Bebedero, Barranca, Tárcoles, Pirrís, Térraba and Coto. 5-100 m. (2).

\section{Genus: Leptophilypnus Meek and Hildebrand, 1916}

220. Leptophilypnus fluviatilis Meek and Hildebrand, 1916. Dwarf guavina, guavina enana. Addition to fauna.

Distribution: Atlantic slope: Tortuguero. 0-6 m.

Remarks: Five specimens have been collected in freshwaters in the Tortuguergo Lagoon (UF 07196, $n=3$; UF 11115, n=1; UF 16348, $n=1$ ), Tortuguero drainage. Thacker et al. (2006) in the redescription of the genus Leptophilypnus included material of this species from the Tortuguero Lagoon (UMMZ 180649, n=1), Tortuguero drainage.

221. Leptophilypnus panamensis (Meek and Hildebrand, 1916). Dwarf guavina, guavina enana. Addition to fauna.

Distribution: Pacific slope: Tárcoles, Pirrís and Térraba. 0-32 m.

Remarks: Twenty-five specimens have been collected in freshwaters in the Lagarto River (UCR 1268-18, n=1), Barranca drainage, the Quebrada Bonita River (UCR 008601, n=3), Tárcoles drainage, the Barú River (UCR 0313-
05, n=12), Pirrís drainage, and the Sábalo River (UCR 1315-01, n=9), Coto drainage. Thacker et al. (2006) in the redescription of the genus Leptophilypnus included material of this species from the Barú River (TU 25132, $\mathrm{n}=129)$, Pirrís drainage, and the Grande de Térraba River (TU 84526, n=6), Térraba drainage.

Family: Gobiidae [11](22). Peripheral.

\section{Genus: Aboma Jordan and Starks, 1895 (1).}

222. Aboma etheostoma Jordan and Starks, 1895. Scaly boy, gobio escamoso. Addition to fauna.

Distribution: Pacific slope: Barranca. 0-32 m.

Remarks: Two specimens have been collected in freshwaters in the Lagarto River (UCR 1268-16), Barranca drainage.

\section{Genus: Awaous Valenciennes, 1837 (2).}

223. Awaous banana (Valenciennes, 1837). River goby, lamearena (396).

Distribution: Atlantic slope: San Juan, San Carlos, Sarapiquí, Tortuguero, Parismina, Matina and Sixaola. Pacific slope: Bebedero (UCR 1569-08). 0-300 m.

224. Awaous transandeanus (Günther, 1861). River goby, lamearena (396).

Distribution: Pacific slope: Nicoya, Tempisque, Bebedero, Barranca, Tárcoles, Pirrís, Térraba and Coto. 0-120 m.

\section{Genus: Bathygobius Bleeker, 1878 (3).}

225. Bathygobius andrei (Sauvage, 1880). Estuarine frillfin, gobio. Addition to fauna.

Distribution: Pacific slope: Barranca, Tárcoles, Pirrís and Térraba. 0-32 m.

Remarks: This species has been reported in the Pacific coast of Costa Rica by Bussing and López (2009). One hundred eleven specimens have been collected in freshwaters in the Lagarto River (UCR 1268-09, $n=1$ ), Barranca drainage, the Quebrada Aserradero River (UCR 0308-03, $n=50$ ), Pirrís drainage, the Esquinas River (UCR 1312-03, n=21; UCR 1314-03, n=35), and the Claro River (UCR 1941-04, n=4), Térraba drainage. Winemiller (1983) and Lyons and Schneider (1990) recorded this species in freshwaters in the Quebrada Camaronal River and the Claro River, Térraba drainage. Alpírez (1985) recorded this species in freshwaters in the Hatillo Nuevo River, Pirrís drainage, and the Punta Mala River, Térraba drainage

226. Bathygobius ramosus Ginsburg, 1947. Panamic frillfin, gobio de pozo. Addition to fauna.

Distribution: Pacific slope: Isla del Coco and Térraba (C. Garita, pers. comm.). 0-10 m.

Remarks: This species has been reported in the Pacific coast of Costa Rica by Bussing and López (2005; 2009). One specimen has been collected in freshwaters in an unknown river name in Cocos Island (UCR 0736-04; $n=1$ ), Isla del Coco drainage. 
227. Bathygobius soporator (Valenciennes, 1837). Frillfin goby, mapo aguado. Addition to fauna.

Distribution: Atlantic slope: Tortuguero, Parismina, Matina and Sixaola. 0-12 m.

Remarks: This species has been reported in the Caribbean coast of Costa Rica by Bussing and López (2009, 2010). Five specimens have been collected in freshwaters in the Tortuguero Lagoon (UCR 1757-12, n=1), Tortuguero drainage, the Suarez River (UCR 0211-04, n=3), Matina drainage, and the Gandoca River (UCR 1847-10, $n=1$ ), Sixaola drainage. Gilbert and Kelso (1971) collected one specimen in freshwaters in the Tortuguero Lagoon, Tortuguero drainage.

\section{Genus: Ctenogobius Gill, 1858 (5).}

228. Ctenogobius boleosoma (Jordan and Gilbert, 1882). Darter goby, madrejuile. Addition to fauna.

Distribution: Atlantic slope: Tortuguero, Parismina, Matina and Sixaola. 0-12 m.

Remarks: This species has been reported in the Caribbean coast of Costa Rica by Bussing and López (2009; 2010). Thirteen specimens have been collected in freshwaters in the Suarez River (UCR 0209-04, n=1; UCR 0779-06, $n=3$ ), the Quebrada Westfalia River (UCR 037608, n=2), Matina drainage, and the Gandoca River (UCR 1847-13, n=7), Sixaola drainage. Gilbert and Kelso (1971) and Winemiller and Leslie (1992), both as Gobionellus boleosoma, recorded this species in freshwaters in the Tortuguero Lagoon, Tortuguero drainage. In the present account, we recognize this species in Ctenogobius following McEachran and Fechhelm (2005), Matamoros et al. (2009), Page and Burr (2011) and Van Tassell (2011).

229. Ctenogobius fasciatus Gill, 1858. Blotchcheek goby, gobio caramarcada. Addition to fauna.

Distribution: Atlantic slope: Tortuguero, Parismina, Matina and Sixaola. 0-12 m.

Remarks: This species has been reported in the Caribbean coast of Costa Rica by Bussing and López (2009; 2010). Eighteen specimens have been collected in freshwaters in the Tortuguero Lagoon (UCR 0260-17, $\mathrm{n}=2$ ), the Colorado River (UCR 1067-17, n=4), the Caño Chiquero River (UCR 1852-14, n=1), Tortuguero drainage, the Quebrada Westfalia River (UCR 0376-07, n=2), Matina drainage, the Sixaola River (UCR 0280-07, $n=1$ ) and the Gandoca River (UCR 1847-04, n=8), Sixaola drainage. Gilbert and Kelso (1971) and Winemiller and Leslie (1992), both as Gobionellus fasciatus, recorded this species in freshwaters in the Tortuguero Lagoon, Tortuguero drainage. In the present account, we recognize this species in Ctenogobius following McEachran and Fechhelm (2005), Matamoros et al. (2009), Page and Burr (2011) and Van Tassell (2011).

230. Ctenogobius pseudofasciatus (Gilbert and Randall, 1971). Slashcheek goby, gobio imitador. Addition to fauna.

Distribution: Atlantic slope: Tortuguero. 0-12 m.

Remarks: This species has been reported in the Caribbean coast of Costa Rica by Bussing and López (2009; 2010). One specimen has been collected in freshwaters in the Tortuguero Lagoon (UF 13516), Tortuguero drainage.
Gilbert and Kelso (1971), as Gobionellus pseudofasciatus, collected four specimens in freshwaters in Tortuguero Lagoon, Tortuguero drainage. In the present account we recognize this species in the genus Ctenogobius following Greenfield and Thomerson (1997), Murdy and Hoese (2003) and Van Tassell (2011).

231. Ctenogobius sagittula (Günther, 1862). Longtail goby, gobio aguzado. Addition to fauna.

Distribution: Pacific slope: Nicoya, Tempisque, Bebedero, Barranca, Tárcoles, Pirrís and Térraba. 0-32 m.

Remarks: This species has been reported in the Pacific coast of Costa Rica by Bussing and López (2009). Fortyfour specimens have been collected in freshwaters in the Calera River (UCR 0935-10, $n=1$ ), Nicoya drainage, the Lagarto River (UCR 1268-12, n=4, UCR 1757-04, n=5, UCR 1793-07, n=1), Barranca drainage, the Quebrada Aserradero River (UCR 0308-02, n=23), Pirrís drainage, and the Quebrada Sucia River (UCR 1314-15, n=10), Térraba drainage. Winemiller (1983) and Lyons and Schneider (1990), both as Gobionellus sagittula, recorded this species in freshwaters in the Quebrada Camaronal River, Térraba drainage. Alpírez (1985), as G. sagittula, recorded this species in freshwaters in the Naranjal River, Tárcoles drainage, the Punta Mala River and the Coronado River, Térraba drainage. In the present account we recognize this species in the genus Ctenogobius following Allen and Robertson (1994), Matamoros et al. (2009) and Van Tassell (2011).

232. Ctenogobius smaragdus (Valenciennes, 1837). Emerald goby, gobio tranquilo. Addition to fauna.

Distribution: Atlantic slope: Tortuguero. 0-4 m.

Remarks: This species has been reported in the Caribbean coast of Costa Rica by Bussing and López (2009; 2010). Three specimens have been collected in freshwaters in the Tortuguero Lagoon (UCR 0260-18).

\section{Genus: Evorthodus Gill 1859 (2).}

233. Evorthodus lyricus (Girard, 1858). Lyre goby, tismiche. Addition to fauna.

Distribution: Atlantic slope: Tortuguero, Parismina, Matina and Sixaola. 0-6 m.

Remarks: This species has been reported in the Caribbean coast of Costa Rica by Bussing and López (2009; 2010). Nine specimens have been collected in freshwaters in the Colorado River (UCR 1067-13, n=2), Tortuguero drainage, the Suarez River (UCR 0209-12, $n=2$ ), the Quebrada Westfalia River (UCR 0376-06, n=1; UCR 112706, $n=1$ ), Matina drainage, and the Sixaola River (UCR 0280-08, n=3), Sixaola drainage. Gilbert and Kelso (1971) and Winemiller and Leslie (1992) recorded this species in freshwaters in the Tortuguero Lagoon, Tortuguero drainage.

234. Evorthodus minutus Meek and Hildebrand, 1928. Small goby, gobio pequeño. Addition to fauna.

Distribution: Pacific slope: Nicoya, Tempisque, Bebedero, Barranca, Tárcoles, Pirrís and Térraba. 0-32 m.

Remarks: This species has been reported in the Pacific coast of Costa Rica by Bussing and López (2009). Forty- 
eight specimens have been collected in freshwaters in the Calera River (UCR 0935-15, $n=39$ ), Nicoya drainage, the Lagarto River (UCR 1268-14, n=1; UCR 1756-05, $n=2$; UCR 1804-05, n=1), Barranca drainage, the Quebrada Aserradero River (UCR 0308-01, n=2), Pirrís drainage, and the Quebrada Sucia River (UCR 1314-14, n=3), Térraba drainage.

\section{Genus: Gobioides Lacepède, 1800 (1).}

235. Gobioides broussonnetii Lacepède, 1800. Violet goby, gobio violeta. Addition to fauna.

Distribution: Atlantic slope: Tortuguero and Parismina. 0-3 m.

Remarks: This species has been reported in the Caribbean coast of Costa Rica by Bussing and López (2009; 2010). Three specimens have been collected in freshwaters in the Colorado River (UCR 0990-16, $n=1$ ), Tortuguero drainage and the Pacuare River (UCR 2835-01, $n=1$; UCR 2859-03, n=1), Parismina drainage.

\section{Genus: Gobionellus Girard, 1858 (1).}

236. Gobionellus microdon (Gilbert, 1892). Estuary goby, gobio de esteros. Addition to fauna.

Distribution: Pacific slope: Nicoya, Barranca, Tárcoles, Pirrís and Térraba. 0-32 m.

Remarks: This species has been reported in the Pacific coast of Costa Rica by Bussing and López (2009). Five hundred fifty-five specimens have been collected in freshwaters in the Calera River (UCR 0935-11, n=159), the Pánica River (UCR 1488-05, n=1), Nicoya drainage, the Lagarto River (UCR 1268-11, n=3), Barranca drainage, the Barú River (UCR 0313-04, n=391), Pirrís drainage, and the Quebrada Indiana River (UCR 0430-04, n=1), Térraba drainage.

\section{Genus: Gobiosoma Girard, 1858 (1).}

237. Gobiosoma spes (Ginsburg, 1939). Vermiculated goby, gobio jaspeado. Addition to fauna.

Distribution: Atlantic slope: Tortuguero. 0-3 m.

Remarks: This species has been reported in the Caribbean coast of Costa Rica by Bussing and López (2009; 2010). Two specimens have been collected in freshwaters in the Tortuguero Lagoon (UCR 0260-10), Tortuguero drainage. Gilbert and Kelso (1971) and Winemiller and Leslie (1992) recorded this species in freshwaters in the Tortuguero Lagoon, Tortuguero drainage.

\section{Genus: Lophiogobius Günther, 1873 (1).}

238. Lophogobius cristulatus Ginsburg, 1939. Pacific crested-goby, gobio crestado. Addition to fauna.

Distribution: Pacific slope: Térraba. 0-17 m.

Remarks: This species has been reported in the Pacific coast of Costa Rica by Bussing and López (2009). Six specimens have been collected in freshwaters in the Quebrada Sucia River (UCR 1314-16), Térraba drainage.
239. Microgobius miraflorensis Gilbert and Starks, 1904. Miraflores goby, gobio de Miraflores. Addition to fauna.

Distribution: Pacific slope: Barranca. 0-32 m.

Remarks: This species has been reported in the Pacific coast of Costa Rica by Bussing and López (2009). Two specimens have been collected in freshwaters in the Lagarto River (UCR 1268-22), Barranca drainage.

\section{Genus: Sicydium Valenciennes, 1837 (4).}

240. Sicydium adelum Bussing, 1996. River goby, chupapiedras (400).

Distribution: Atlantic slope: Parismina, Matina and Sixaola. 10-800 m (Bussing 1996).

Remarks: This species is endemic to the Parismina, Matina and Sixaola River drainages, Costa Rica (Bussing 1996; 1998).

241. Sicydium altum Meek, 1907. River goby, chupapiedras (402).

Distribution: Atlantic slope: Sarapiquí, Tortuguero, Parismina, Matina and Sixaola. 0-1180 m.

242. Sicydium cocoensis (Heller and Snodgrass, 1903). River goby, chupapiedras. Addition to fauna.

Distribution: Pacific slope: Isla del Coco. 0-62 m.

Remarks: This species has been reported in the saltwaters of the Cocos Island National Park, Costa Rica by Bussing (1996). Four hundred seventy-three specimens have been collected in freshwaters in several rivers and streams of unknow name in the Chatam and Wafer Bays (CAS 37542, n=37; LACM 26166, n=37; LACM 35473-008, $\mathrm{n}=5$; LACM 38113-001, n=21; LACM 38113-002, $\mathrm{n}=11$; UCR 0006-01, n=3; UCR 0008-02, $\mathrm{n}=1$; UCR 0736-06, $\mathrm{n}=205$; UCR 1960-01, n=2), the Genio River (LSUMZ 08755, n=83; LSUMZ 08756, n=44; UCR 2020-02, n=7) and the San José River (LSUMZ 08757, n=17), Isla del Coco drainage. This species is endemic to the Isla del Coco drainage, Costa Rica (Bussing 1996; 1998; Bussing and López 2005; Van Tassell 2011).

243. Sicydium salvini Ogilvie-Grant, 1884. River goby, chupapiedras (406).

Distribution: Pacific slope: Nicoya, Tempisque, Bebedero, Barranca, Tárcoles, Pirrís and Térraba. 0-660 m.

\section{Family: Microdesmidae [1](1). Peripheral.}

\section{Genus: Microdesmus Günther, 1864 (1).}

244. Microdesmus dorsipunctatus Dawson, 1968. Spotback wormfish, pez lombriz lomo punteado. Addition to fauna.

Distribution: Pacific slope: Pirrís. 0-3 m.

Remarks: This species has been reported in the Pacific coast of Costa Rica by Bussing and López (2009). Two specimens have been collected in freshwaters in the Quebrada Aserradero River (UCR 0308-06), Pirrís drainage.

\section{Order: Pleuronectiformes 2[3](11).}


Family: Paralichthyidae [1](4). Peripheral.

\section{Genus: Citharichthys Bleeker, 1862 (4).}

245. Citharichthys arenaceus Evermann and Marsh, 1900. Sand whiff, lenguado arenero. Addition to fauna.

Distribution: Atlantic slope: Tortuguero, Parismina, Matina and Sixaola. 0-60 m.

Remarks: Eleven specimens have been collected in freshwaters in the Pacuare River (UCR 0209-07, $n=1$ ), Parismina drainage, the Suarez River (UCR 0590-01, $n=1$ ), the Banano River (UCR 0374-09; n=1) and the Hone Creek River (UCR 1352-13, n=8), Matina drainage

246. Citharichthys gilberti Jenkins and Evermann, 1889. Bigmouth sanddab, lenguado tapadero. Addition to fauna.

Distribution: Pacific slope: Nicoya, Barranca, Tárcoles, Pirrís and Térraba. 0-80 m (A. Molina, pers. comm.).

Remarks: This species has been reported in the Pacific coast of Costa Rica by Bussing and López (1994; 2009; 2011). Fifty-four specimens have been collected in freshwaters in the Calera River (UCR 0935-09, $n=1$ ), Nicoya drainage, the Lagarto River (UCR 1268-02, $n=4$; UCR 1793-04, n=14), Barranca drainage, the Quebrada Doña María River (UCR 0115-08, n=1), Tárcoles drainage, the Quebrada Aserradero River (UCR 0308-11, n=30), Pirrís drainage, the Esquinas River (UCR 1312-06, $n=1$ ) and the Quebrada Sucia River (UCR 1314-07, $n=3$ ), Térraba drainage. Alpírez (1985) recorded this species in freshwaters in the Montaña River, the Nosara River, the Garza River, the Buenavista River, the Pánica River, Nicoya drainage, the Tulín River, Tárcoles drainage, the Parrita River, the Paquita River, the Portalón River, Pirrís drainage, and the Punta Mala River, Térraba drainage.

247. Citharichthys spilopterus Günther, 1862. Bay whiff, lenguado pardo (428).

Distribution: Atlantic slope: Tortuguero, Parismina, Matina and Sixaola. 0-60 m.

248. Citharichthys uhleri Jordan, 1889. Voodoo whiff, lenguado albimoteado (430).

Distribution: Atlantic slope: Tortuguero, Parismina, Matina and Sixaola. 0-60 m.

Family: Achiridae [2](7). Peripheral.

\section{Genus: Achirus Lacepède, 1802 (3).}

249. Achirus declivis Chabanaud, 1940. Plainfin sole, suela común. Addition to fauna.

Distribution: Atlantic slope: Tortuguero and Parismina. 0-3 m.

Remarks: This species has been reported in the Caribbean coast of Costa Rica by Bussing and López (2009; 2010). Two specimens have been collected in freshwaters in the Tortuguero Lagoon (UCR 0260-16, n=1), Tortuguero drainage, and the Pacuare River (UCR 2859-01, $n=1$ ), Parismina drainage.

250. Achirus lineatus (Linnaeus, 1758). Lined sole, suela listada. Addition to fauna.
Distribution: Atlantic slope: Tortuguero and Matina. 0-5 m.

Remarks: This species has been reported in the Caribbean coast of Costa Rica by Bussing and López (2009; 2010). One specimen has been collected in freshwaters in the Quebrada Westfalia River (UCR 0376-14), Matina drainage. Winemiller and Leslie (1992) recorded this species in freshwaters in the Tortuguero Lagoon, Tortuguero drainage.

251. Achirus mazatlanus (Steindachner, 1869). Mazatlan sole, lenguado listado. Addition to fauna.

Distribution: Pacific slope: Nicoya, Barranca and Pirrís. 0-32 m.

Remarks: This species has been reported in the Pacific coast of Costa Rica by Bussing and López (1994; 2009; 2011). Twelve specimens have been collected in freshwaters in the Calera River (UCR 0935-14, n=2), Nicoya drainage, the Lagarto River (UCR 1268-21, n=8), Barranca drainage, and the Quebrada Aserrader River (UCR 030810, n=2), Pirrís drainage.

\section{Genus: Trinectes Rafinesque, 1832 (4).}

252. Trinectes fimbriatus (Günther, 1862). Fringed sole, lenguado manchado. Addition to fauna.

Distribution: Pacific slope: Barranca. 0-32 m.

Remarks: This species has been reported in the Pacific coast of Costa Rica by Bussing and López (1994; 2009; 2011). Two specimens have been collected in freshwaters in the Lagarto River (UCR 1268-15), Barranca drainage.

253. Trinectes fonsecensis (Günther, 1862). Spottedfin sole, lenguado rayado (432).

Distribution: Pacific slope: Barranca, Tárcoles, Pirrís and Térraba. 0-55 m (Rojas and Rodríguez 2008).

254. Trinectes inscriptus (Gosse, 1851). Scrawled sole, suela reticulada. Addition to fauna.

Distribution: Atlantic slope: Matina. 0-5 m.

Remarks: This species has been reported in the Caribbean coast of Costa Rica by Bussing and López (2009; 2010). Four specimens have been collected in freshwaters in the Suarez River (UCR 0209-11, n=1) and the Quebrada Westfalia River (UCR 0376-14, n=3), Matina drainage.

255. Trinectes paulistanus (Miranda Ribeiro, 1915). Slipper sole, suela carioca (434).

Distribution: Atlantic slope: Tortuguero, Parismina, Matina and Sixaola. 0-10 m.

\section{Order: Tetraodontiformes 1[1](3).}

Family: Tetraodontidae [1](3). Peripheral.

\section{Genus: Sphoeroides [Lacepède], 1798 (3).}

256. Sphoeroides annulatus (Jenyns, 1842). Bullseye puffer, timboril anillado. Addition to fauna.

Distribution: Pacific slope: Barranca and Térraba. 0-5 m.

Remarks: This species has been reported in the 
Pacific coast of Costa Rica by Bussing and López (1994; 2009; 2011). Seven specimens have been collected in freshwaters in the Lagarto River (UCR 1793-05, $n=5$ ), Barranca drainage, and the Sirena River (UCR 1872-03, $\mathrm{n}=2$ ), Térraba drainage. Winemiller (1983), Winemiller and Morales (1989) and Lyons and Schneider (1990) recorded this species in freshwaters in the Quebrada Camaronal River and the Claro River, Térraba drainage. Alpírez (1985) recorded this species in freshwaters in the Paquita River, Pirrís drainage.

257. Sphoeroides rosenblatti Bussing, 1996. Bullseye puffer, timboril imitador. Addition to fauna.

Distribution: Pacific slope: Barranca and Térraba. 0-32 m.

Remarks: This species has been reported in the Pacific coast of Costa Rica by Bussing and López (1994, as Sphoeroides sp.; 2009). Twenty-nine specimens have been collected in freshwaters in the Lagarto River (UCR 1268-04, n=14; UCR 1793-06, n=12), Barranca drainage, the Rincón River (UCR 0262-04, n=1) and the Claro River (UCR 1869-01, n=2), Térraba drainage.

258. Sphoeroides testudineus (Linnaeus, 1758). Checkered puffer, botete sapo. Addition to fauna.

Distribution: Atlantic slope: Tortuguero. 0-12 m.

Remarks: This species has been reported in the Caribbean coast of Costa Rica by Bussing and López (2009; 2010). Sixty-two specimens have been collected in freshwaters in the Tortuguero Lagoon (UCR 0260-06, $\mathrm{n}=13$; UCR 0261-04, $\mathrm{n}=40$; UCR 1757-04, $\mathrm{n}=3$; UCR 185402, $\mathrm{n}=1$; UCR 2495-10, $\mathrm{n}=3$ ), the Colorado River (UCR 1078-03, n=1) and the Gandoca River (UCR 1882-03, n=1), Tortuguero drainage. Gilbert and Kelso (1971) collected two specimens in freshwaters in the Tortuguero Lagoon, Tortuguero drainage.

\section{Discussion}

Bussing (1998) reported a total of 142 native species for the country, $22.5 \%$ (32 species) of which, based on published salinity tolerances (Myers 1949), are primary or obligate freshwater, $40.2 \%$ (57 species) are secondary and $37.3 \%$ (53 species) are peripheral. Our results indicate the presence of a total of 250 species, 33 (13.2\%) of which are native primary species, 59 (23.6\%) native secondary species and 158 (63.2\%) native peripheral species. These results are not surprising, given Myers' (1966) suggested history and composition of the Central American freshwater fish fauna.

With the exception of Panama, all Central American countries now have fairly recent formal freshwater fish species lists. These lists include: Nicaragua (Villa 1982), El Salvador (McMahan et al. 2013), Honduras (Matamoros et al. 2009), Guatemala (Kihn-Pineda et al. 2006) and Belize (Greenfield and 1997). The last formal list for Panama dates back to 1965 (Loftin 1965).

Compared with the other Central American countries, except Panama, Costa Rica appears to have the greatest primary freshwater fish diversity with 33 species. About $60 \%$ (19) of those species are known to be present both in Costa Rica and Panama (Bussing 1998; Froese and Pauly 2013), whereas less than 40\% (13) are known to be present both in Costa Rica and Nicaragua (Villa 1982; Bussing 1998; Froese and Pauly 2013). Northward the number of shared primary species decreases gradually: Honduras (7), Guatemala (6), Mexico (5), El Salvador (4) and Belize (3) (Greenfield and Thomerson 1997; Bussing 1998; Kihn-Pineda et al. 2006; Matamoros et al. 2009; Froese and Pauly 2013; McMahan et al. 2013).

Bussing (1998) reported a total of nineteen endemic species from the country; our results indicate the presence of a total of twenty-four endemic species. In this account, we exclude Gobiesox potamius reported by McMahan et al. (2013) from El Salvador, but include three endemic species of the Cocos Island (Eleotris tubularis, Gobiesox fulvus and Sicydium cocoensis), the recently described Poeciliopsis santaelena, and Cynodonichthys siegfriedi herein recognized as valid species, to the list of endemic species of Costa Rica. Finally, Bussing (1998) mentioned at least seven exotic species from the country; in this account we confirmed the presence of at least eight exotic species in natural water bodies of the country.

The results of this checklist provide a framework for future biogeographic works on fishes from this region, particularly by providing up-to-date knowledge on distributions. In addition, data provided in this checklist will help on monitoring fish distributional changes in the future due to human introductions and global change and will aid in conservation decisions concerning Costa Rican fishes.

TABLE 1. Costa Rican freshwater fish species by major River drainage basins (Figure 1). Ele refers to altitudinal distribution in meters above sea level. Sal refers to tolerance to salinity based on Meyers (1949); primary = Pri; secondary = Sec; and peripheral = Per. CSt stands for conservation status; species were classified as native (Nat), endemic (End) and exotic (Exo). Afa refers to additions to fauna on the basis of Bussing (1998).

\begin{tabular}{|c|c|c|c|c|c|c|c|c|c|c|c|c|c|c|c|c|c|c|c|c|c|c|}
\hline \multirow{2}{*}{ FAMILY/Species } & \multicolumn{9}{|c|}{ Atlantic slope } & \multicolumn{9}{|c|}{ Pacific slope } & \multirow{2}{*}{ Ele } & \multirow{2}{*}{ Sal } & \multirow{2}{*}{ CSt } & \multirow{2}{*}{ Afa } \\
\hline & LN & $\mathbf{R F}$ & SJ & SC & Sa & To & $\mathrm{Pa}$ & Ma & $\mathbf{S i}$ & IC & $\mathrm{Ni}$ & Te & $\mathrm{Be}$ & $\mathrm{Ba}$ & Ta & $\mathbf{P i}$ & $\operatorname{Tr}$ & Co & & & & \\
\hline \multicolumn{23}{|c|}{ CARCHARHINIDAE (1) } \\
\hline Carcharhinus leucas & $\mathrm{X}$ & $\mathrm{X}$ & $\mathrm{X}$ & $\mathrm{X}$ & $\mathrm{X}$ & $\mathrm{X}$ & & & & & & & & & & & $\mathrm{X}$ & & $0-35$ & Per & Nat & \\
\hline \multicolumn{23}{|l|}{ PRISTIDAE (2) } \\
\hline Pristis pectinata & $\mathrm{X}$ & & $\mathrm{X}$ & & & $\mathrm{X}$ & & & & & & & & & & & $\mathrm{X}$ & & $0-35$ & Per & Nat & $\mathrm{X}$ \\
\hline Pristis pristis & $\mathrm{X}$ & $\mathrm{X}$ & $\mathrm{X}$ & $\mathrm{X}$ & $\mathrm{X}$ & $\mathrm{X}$ & & & & & & $\mathrm{X}$ & & & & & & & $0-35$ & Per & Nat & \\
\hline Atractosteus tropicus & $\mathrm{X}$ & $\mathrm{X}$ & $\mathrm{X}$ & $\mathrm{X}$ & $\mathrm{X}$ & $\mathrm{X}$ & $\mathrm{X}$ & & & & & & & & & & & & $0-45$ & $\mathrm{Sec}$ & Nat & \\
\hline \multicolumn{23}{|l|}{ ELOPIDAE (1) } \\
\hline Elops affinis & & & & & & & & & & & $\mathrm{X}$ & & & & & & & & $0-10$ & Per & Nat & $\mathrm{X}$ \\
\hline \multicolumn{23}{|l|}{ MEGALOPIDAE (1) } \\
\hline Megalops atlanticus & $\mathrm{X}$ & $\mathrm{X}$ & $\mathrm{X}$ & $\mathrm{X}$ & $\mathrm{X}$ & $\mathrm{X}$ & & & & & & & & & & & & & $0-45$ & Per & Nat & \\
\hline
\end{tabular}


TABle 1. Continued.

\begin{tabular}{|c|c|c|c|c|c|c|c|c|c|c|c|c|c|c|c|c|c|c|c|c|c|c|}
\hline \multirow{2}{*}{ FAMILY/Species } & \multicolumn{9}{|c|}{ Atlantic slope } & \multicolumn{9}{|c|}{ Pacific slope } & \multirow{2}{*}{ Ele } & \multirow{2}{*}{ Sal } & \multirow{2}{*}{ CSt } & \multirow{2}{*}{ Afa } \\
\hline & $\mathbf{L N}$ & $\mathbf{R F}$ & SJ & SC & Sa & To & $\mathrm{Pa}$ & Ma & Si & IC & $\mathrm{Ni}$ & Te & $\mathrm{Be}$ & Ba & Ta & $\mathbf{P i}$ & $\operatorname{Tr}$ & Co & & & & \\
\hline ALBULIDAE (1) & & & & & & & & & & & & & & & & & & & & & & \\
\hline Albula vulpes & & & & & & & & $\mathrm{X}$ & & & & & & & & & & & $0-2$ & Per & Nat & $\mathrm{X}$ \\
\hline ANGUILLIDAE (1) & & & & & & & & & & & & & & & & & & & & & & \\
\hline Anguilla rostrata & $\mathrm{X}$ & $\mathrm{X}$ & $\mathrm{X}$ & $\mathrm{X}$ & $\mathrm{X}$ & $\mathrm{X}$ & $\mathrm{X}$ & $\mathrm{X}$ & $\mathrm{X}$ & & & & & & & & & & $0-20$ & Per & Nat & \\
\hline OPHICHTHIDAE (2) & & & & & & & & & & & & & & & & & & & & & & \\
\hline Myrophis punctatus & & & & & & & & $\mathrm{X}$ & & & & & & & & & & & $0-3$ & Per & Nat & $\mathrm{X}$ \\
\hline Myrophis vafer & & & & & & & & & & & & & & & & & $\mathrm{X}$ & & $0-17$ & Per & Nat & $\mathrm{X}$ \\
\hline CLUPEIDAE (4) & & & & & & & & & & & & & & & & & & & & & & \\
\hline Dorosoma chavesi & $\mathrm{X}$ & $\mathrm{X}$ & $\mathrm{X}$ & $\mathrm{X}$ & $\mathrm{X}$ & $\mathrm{X}$ & & & & & & & & & & & & & $0-50$ & Per & Nat & \\
\hline Lile piquitinga & & & & & & & & & $\mathrm{X}$ & & & & & & & & & & $0-66$ & Per & Nat & $\mathrm{X}$ \\
\hline Lile stolifera & & & & & & & & & & & & & & & & & $\mathrm{X}$ & & $0-10$ & Per & Nat & $\mathrm{X}$ \\
\hline Sardinella brasiliensis & & & & & & $\mathrm{X}$ & & & & & & & & & & & & & $0-3$ & Per & Nat & $X$ \\
\hline ENGRAULIDAE (5) & & & & & & & & & & & & & & & & & & & & & & \\
\hline Anchoa curta & & & & & & & & & & & & & & & & & $\mathrm{X}$ & & $0-12$ & Per & Nat & $\mathrm{X}$ \\
\hline Anchoa lucida & & & & & & & & & & & & & & $\mathrm{X}$ & & & & & $0-32$ & Per & Nat & $\mathrm{X}$ \\
\hline Anchovia macrolepidota & & & & & & & & & & & & & & & & & $\mathrm{X}$ & & $0-17$ & Per & Nat & $\mathrm{X}$ \\
\hline Anchoviella elongata & & & & & & $\mathrm{X}$ & $\mathrm{X}$ & & & & & & & & & & & & $0-5$ & Per & Nat & $\mathrm{X}$ \\
\hline Lycengraulis grossidens & & & & & & $\mathrm{X}$ & & & & & & & & & & & & & $0-3$ & Per & Nat & $\mathrm{X}$ \\
\hline CYPRINIDAE (2) & & & & & & & & & & & & & & & & & & & & & & \\
\hline Carassius auratus & & & & & & & & & & & & & & & $\mathrm{X}$ & & & & $100-1779$ & Pri & Exo & \\
\hline Cyprinus carpio & & & & & & & & & & & & & & & $\mathrm{X}$ & & & & $112-1516$ & Pri & Exo & $\mathrm{X}$ \\
\hline CURIMATIDAE (1) & & & & & & & & & & & & & & & & & & & & & & \\
\hline Cyphocharax magdalenae & & & & & & & & & & & & & & & & & & $\mathrm{X}$ & $12-100$ & Pri & Nat & \\
\hline ERYTHRINIDAE (1) & & & & & & & & & & & & & & & & & & & & & & \\
\hline Hoplias microlepis & & & & & & & & & & & & & & & & & & $\mathrm{X}$ & $20-40$ & Pri & Nat & \\
\hline LEBIASINIDAE (1) & & & & & & & & & & & & & & & & & & & & & & \\
\hline Lebiasina boruca & & & & & & & & & & & & & & & & $\mathrm{X}$ & $\mathrm{X}$ & $\mathrm{X}$ & $10-1000$ & Pri & End & \\
\hline CHARACIDAE (19) & & & & & & & & & & & & & & & & & & & & & & \\
\hline Astyanax aeneus & $\mathrm{X}$ & $\mathrm{X}$ & $\mathrm{X}$ & $\mathrm{X}$ & $\mathrm{X}$ & $\mathrm{X}$ & $\mathrm{X}$ & $\mathrm{X}$ & $\mathrm{X}$ & & $\mathrm{X}$ & $\mathrm{X}$ & $\mathrm{X}$ & $\mathrm{X}$ & $\mathrm{X}$ & $\mathrm{X}$ & $\mathrm{X}$ & $\mathrm{X}$ & $0-1000$ & Pri & Nat & \\
\hline Astyanax cocibolca & $X$ & $\mathrm{X}$ & $\mathrm{X}$ & $X$ & $\mathrm{X}$ & $\mathrm{X}$ & & & & & & & & & & & & & $5-20$ & Pri & Nat & \\
\hline Astyanax orthodus & & & & & & & & & $\mathrm{X}$ & & & & & & & & & & $1-60$ & Pri & Nat & \\
\hline Bramocharax bransfordii & $\mathrm{X}$ & $\mathrm{X}$ & $\mathrm{X}$ & $\mathrm{X}$ & $\mathrm{X}$ & $\mathrm{X}$ & $X$ & & & & & & & & & & & & $5-530$ & Pri & Nat & \\
\hline Brycon behreae & & & & & & & & & & & & & & & & $\mathrm{X}$ & $\mathrm{X}$ & $\mathrm{X}$ & $10-640$ & Pri & Nat & \\
\hline Brycon costaricensis & $\mathrm{X}$ & $\mathrm{X}$ & $\mathrm{X}$ & $X$ & $\mathrm{X}$ & $\mathrm{X}$ & $X$ & $\mathrm{X}$ & & & & & & & & & & & $0-600$ & Pri & Nat & \\
\hline Bryconamericus gonzalezi & & & & & & & & & $X$ & & & & & & & & & & 69 & Pri & Nat & $X$ \\
\hline Bryconamericus scleroparius & $\mathrm{X}$ & $\mathrm{X}$ & $\mathrm{X}$ & $\mathrm{X}$ & $\mathrm{X}$ & $\mathrm{X}$ & $\mathrm{X}$ & $\mathrm{X}$ & $X$ & & & $\mathrm{X}$ & & & & & & & $12-600$ & Pri & Nat & \\
\hline Bryconamericus terrabensis & & & & & & & & & & & & & & & & & $\mathrm{X}$ & & $60-940$ & Pri & End & \\
\hline Carlana eigenmanni & $\mathrm{X}$ & $\mathrm{X}$ & $\mathrm{X}$ & $\mathrm{X}$ & $\mathrm{X}$ & $\mathrm{X}$ & $\mathrm{X}$ & & & & & & & & & & & & $35-90$ & Pri & Nat & \\
\hline Hyphessobrycon panamensis & & & & & & & & & $\mathrm{X}$ & & & & & & & & & & $40-60$ & Pri & Nat & \\
\hline Hyphessobrycon savagei & & & & & & & & & & & & & & & & $\mathrm{X}$ & $\mathrm{X}$ & & $0-70$ & Pri & End & \\
\hline Hyphessobrycon tortuguerae & $\mathrm{X}$ & $\mathrm{X}$ & $\mathrm{X}$ & $\mathrm{X}$ & $\mathrm{X}$ & $\mathrm{X}$ & & & & & & & & & & & & & $0-50$ & Pri & Nat & \\
\hline Odontostilbe dialeptura & & & & & & & & & & & & & & & & & & $\mathrm{X}$ & $20-90$ & Pri & Nat & \\
\hline Pseudocheirodon Térrabae & & & & & & & & & & & & & & & & $\mathrm{X}$ & $\mathrm{X}$ & & $0-680$ & Pri & End & \\
\hline Pterobrycon myrnae & & & & & & & & & & & & & & & & $X$ & $\mathrm{X}$ & & $10-80$ & Pri & End & \\
\hline Roeboides bouchellei & $\mathrm{X}$ & $\mathrm{X}$ & $\mathrm{X}$ & $X$ & $\mathrm{X}$ & $\mathrm{X}$ & $X$ & $\mathrm{X}$ & & & $\mathrm{X}$ & $\mathrm{X}$ & $\mathrm{X}$ & $\mathrm{X}$ & & & & & $0-610$ & Pri & Nat & \\
\hline Roeboides bussingi & & & & & & & & & & & & & & & & & & $\mathrm{X}$ & $11-118$ & Pri & Nat & \\
\hline Roeboides ilseae & & & & & & & & & & & & & & & & $X$ & $\mathrm{X}$ & & $10-660$ & Pri & End & \\
\hline ARIIDAE (6) & & & & & & & & & & & & & & & & & & & & & & \\
\hline Cathorops steindachneri & & & & & & & & & & & & $\mathrm{X}$ & & & & & $\mathrm{X}$ & & $0-55$ & Per & Nat & $\mathrm{X}$ \\
\hline Cathorops tuyra & & & & & & & & & & & & $\mathrm{X}$ & & & & & $\mathrm{X}$ & & $0-55$ & Per & Nat & $X$ \\
\hline Notarius cookei & & & & & & & & & & & $\mathrm{X}$ & & & & & & & & $0-6$ & Per & Nat & $X$ \\
\hline Sciades assimilis & & & & & & & $\mathrm{X}$ & & & & & & & & & & & & $0-7$ & Per & Nat & $\mathrm{X}$ \\
\hline Sciades guatemalensis & & & & & & & & & & & & $\mathrm{X}$ & & & & & & & $0-11$ & Per & Nat & \\
\hline Sciades seemanni & & & & & & & & & & & $\mathrm{X}$ & $\mathrm{X}$ & $\mathrm{X}$ & $\mathrm{X}$ & $\mathrm{X}$ & & $\mathrm{X}$ & & $0-32$ & Per & Nat & \\
\hline HEPTAPTERIDAE (5) & & & & & & & & & & & & & & & & & & & & & & \\
\hline Imparfinis lineatus & & & & & & & & & & & & & & & & & $\mathrm{X}$ & & $80-980$ & Pri & End & \\
\hline Pimelodella chagresi & & & & & & & & & & & & & & & & & $\mathrm{X}$ & $\mathrm{X}$ & $20-660$ & Pri & Nat & \\
\hline Rhamdia guatemalensis & $X$ & $X$ & $X$ & $\mathrm{X}$ & $X$ & $X$ & $X$ & $X$ & $\mathrm{X}$ & & $X$ & $\mathrm{X}$ & $\mathrm{X}$ & $X$ & $\mathrm{X}$ & $\mathrm{X}$ & $\mathrm{X}$ & $\mathrm{X}$ & $0-680$ & Pri & Nat & \\
\hline Rhamdia laticauda & $\mathrm{X}$ & $\mathrm{X}$ & $\mathrm{X}$ & $\mathrm{X}$ & $\mathrm{X}$ & $X$ & $\mathrm{X}$ & $X$ & $\mathrm{X}$ & & & $\mathrm{X}$ & $\mathrm{X}$ & $X$ & $\mathrm{X}$ & $\mathrm{X}$ & $\mathrm{X}$ & $\mathrm{X}$ & $35-1350$ & Pri & Nat & \\
\hline Rhamdia nicaraguensis & $\mathrm{X}$ & $\mathrm{X}$ & $\mathrm{X}$ & $\mathrm{X}$ & $\mathrm{X}$ & $\mathrm{X}$ & $\mathrm{X}$ & & & & & $\mathrm{X}$ & $\mathrm{X}$ & & $\mathrm{X}$ & & & & $20-1160$ & Pri & Nat & \\
\hline
\end{tabular}


TABle 1. Continued.

\begin{tabular}{|c|c|c|c|c|c|c|c|c|c|c|c|c|c|c|c|c|c|c|c|c|c|c|}
\hline \multirow{2}{*}{ FAMILY/Species } & \multicolumn{9}{|c|}{ Atlantic slope } & \multicolumn{9}{|c|}{ Pacific slope } & \multirow{2}{*}{ Ele } & \multirow{2}{*}{ Sal } & \multirow{2}{*}{ CSt } & $f$ \\
\hline & LN & $\mathbf{R F}$ & SJ & SC & Sa & To & $\mathrm{Pa}$ & Ma & Si & IC & $\mathrm{Ni}$ & Te & $\mathrm{Be}$ & $\mathbf{B a}$ & Ta & $\mathbf{P i}$ & $\operatorname{Tr}$ & Co & & & & Ald \\
\hline TRICHOMYCTERIDAE (1) & & & & & & & & & & & & & & & & & & & & & & \\
\hline Trichomycterus striatus & & & & & & & & & & & & & & & & & $\mathrm{X}$ & $\mathrm{X}$ & $20-660$ & Pri & Nat & \\
\hline LORICARIDAE (3) & & & & & & & & & & & & & & & & & & & & & & \\
\hline Fonchiiichthys uracanthus & & & & & & & & & & & & & & & & & & $\mathrm{X}$ & $20-160$ & Pri & Nat & \\
\hline Hemiancistrus aspidolepis & & $\mathrm{X}$ & & & & & $\mathrm{X}$ & & & & & & & & & & $\mathrm{X}$ & $\mathrm{X}$ & $20-560$ & Pri & Nat & \\
\hline Pterygoplichthys pardalis & & & & & & & $\mathrm{X}$ & & & & & & & & & & & & $20-110$ & Pri & Exo & $\mathrm{X}$ \\
\hline GYMNOTIDAE (2) & & & & & & & & & & & & & & & & & & & & & & \\
\hline Gymnotus cylindricus & $\mathrm{X}$ & $\mathrm{X}$ & $\mathrm{X}$ & $\mathrm{X}$ & $\mathrm{X}$ & $\mathrm{X}$ & $\mathrm{X}$ & $\mathrm{X}$ & $\mathrm{X}$ & & & & & & & & & & $1-50$ & Pri & Nat & \\
\hline Gymnotus maculosus & $X$ & $\mathrm{X}$ & $X$ & $X$ & $\mathrm{X}$ & $X$ & & & & & $\mathrm{X}$ & $\mathrm{X}$ & $\mathrm{X}$ & & & & & & $20-540$ & Pri & Nat & \\
\hline HYPOPOMIDAE (1) & & & & & & & & & & & & & & & & & & & & & & \\
\hline Brachyhypopomus occidentalis & & & & & & & & & $\mathrm{X}$ & & & & & & & & & & $1-60$ & Pri & Nat & \\
\hline SALMONIDAE (1) & & & & & & & & & & & & & & & & & & & & & & \\
\hline Oncorhynchus mykiss & & & & & & & $\mathrm{X}$ & & & & & & & & & $\mathrm{X}$ & & & $654-2202$ & Per & Exo & \\
\hline GOBIESOCIDAE (3) & & & & & & & & & & & & & & & & & & & & & & \\
\hline Gobiesox fulvus & & & & & & & & & & $\mathrm{X}$ & & & & & & & & & $0-304$ & Per & End & \\
\hline Gobiesox nudus & & & & $\mathrm{X}$ & $\mathrm{X}$ & $\mathrm{X}$ & $\mathrm{X}$ & $\mathrm{X}$ & $\mathrm{X}$ & & & & & & & & & & $25-580$ & Per & Nat & \\
\hline Gobiesox potamius & & & & & & & & & & & $\mathrm{X}$ & $\mathrm{X}$ & $\mathrm{X}$ & $\mathrm{X}$ & $\mathrm{X}$ & $\mathrm{X}$ & $\mathrm{X}$ & & $0-140$ & Per & Nat & \\
\hline ATHERINOPSIDAE (7) & & & & & & & & & & & & & & & & & & & & & & \\
\hline Atherinella argentea & & & & & & & & & & & $\mathrm{X}$ & $\mathrm{X}$ & $\mathrm{X}$ & $\mathrm{X}$ & $\mathrm{X}$ & $\mathrm{X}$ & $\mathrm{X}$ & $\mathrm{X}$ & $0-7$ & Per & Nat & \\
\hline Atherinella blackburni & & & & & & $\mathrm{X}$ & & & & & & & & & & & & & $0-3$ & Per & Nat & $\mathrm{X}$ \\
\hline Atherinella chagresi & & & & & & $X$ & $\mathrm{X}$ & $\mathrm{X}$ & $\mathrm{X}$ & & & & & & & & & & $8-60$ & Per & Nat & \\
\hline Atherinella hubbsi & $\mathrm{X}$ & $\mathrm{X}$ & $\mathrm{X}$ & $\mathrm{X}$ & $\mathrm{X}$ & $\mathrm{X}$ & $\mathrm{X}$ & $\mathrm{X}$ & & & & & & & & & & & $35-540$ & Per & Nat & \\
\hline Atherinella milleri & $\mathrm{X}$ & $\mathrm{X}$ & $\mathrm{X}$ & $X$ & $\mathrm{X}$ & $\mathrm{X}$ & $\mathrm{X}$ & $\mathrm{X}$ & $\mathrm{X}$ & & & & & & & & & & $0-40$ & Per & Nat & \\
\hline Atherinella sardina & $\mathrm{X}$ & & & & & & & & & & & & & & & & & & $0-40$ & Per & Nat & \\
\hline Membras gilberti & & & & & & & & & & & & & & $\mathrm{X}$ & $\mathrm{X}$ & $\mathrm{X}$ & $\mathrm{X}$ & & $0-7$ & Per & Nat & $\mathrm{X}$ \\
\hline RIVULIDAE (7) & & & & & & & & & & & & & & & & & & & & & & \\
\hline Cynodonichthys fuscolineatus & & & & & $\mathrm{X}$ & & & & & & & & $\mathrm{X}$ & & & & & & $525-695$ & Sec & End & \\
\hline Cynodonichthys glaucus & & & & & & & & & & & & & & & & & $\mathrm{X}$ & $\mathrm{X}$ & $540-680$ & Sec & End & \\
\hline Cynodonichthys hildebrandi & & & & & & & & & & & & & & & & & $\mathrm{X}$ & $X$ & $10-90$ & $\mathrm{Sec}$ & Nat & \\
\hline Cynodonichthys isthmensis & $\mathrm{X}$ & $\mathrm{X}$ & $\mathrm{X}$ & $\mathrm{X}$ & $\mathrm{X}$ & $\mathrm{X}$ & $\mathrm{X}$ & $\mathrm{X}$ & $\mathrm{X}$ & & & & $\mathrm{X}$ & & $\mathrm{X}$ & & & & $0-1500$ & $\mathrm{Sec}$ & Nat & \\
\hline Cynodonichthys rubripunctatus & & & & & & & & & $\mathrm{X}$ & & & & & & & & & & $2-40$ & Sec & Nat & \\
\hline Cynodonichthys siegfriedi & & & & & & & & & & & & & & & & & $\mathrm{X}$ & & $20-80$ & Sec & End & \\
\hline Cynodonichthys uroflammeus & & & & & & & & & & & & & & & & & $\mathrm{X}$ & $\mathrm{X}$ & $750-1100$ & $\mathrm{Sec}$ & Nat & \\
\hline ANABLEPIDAE (1) & & & & & & & & & & & & & & & & & & & & & & \\
\hline Oxyzygonectes dovii & & & & & & & & & & & $\mathrm{X}$ & $X$ & $\mathrm{X}$ & $\mathrm{X}$ & $\mathrm{X}$ & $\mathrm{X}$ & $\mathrm{X}$ & $\mathrm{X}$ & $0-15$ & $\mathrm{Sec}$ & Nat & \\
\hline POECILIIDAE (25) & & & & & & & & & & & & & & & & & & & & & & \\
\hline Alfaro cultratus & $\mathrm{X}$ & $X$ & $X$ & $X$ & $\mathrm{X}$ & $X$ & $X$ & $\mathrm{X}$ & $\mathrm{X}$ & & & $X$ & & & & & & & $0-300$ & $\mathrm{Sec}$ & Nat & \\
\hline Belonesox belizanus & $X$ & $\mathrm{X}$ & $X$ & $X$ & $X$ & $X$ & $\mathrm{X}$ & $\mathrm{X}$ & & & & & & & & & & & $0-45$ & $\mathrm{Sec}$ & Nat & \\
\hline Brachyrhaphis cascajalensis & & & & & & & & & $\mathrm{X}$ & & & & & & & & & & $5-125$ & $\mathrm{Sec}$ & Nat & \\
\hline Brachyrhaphis holdridgei & $\mathrm{X}$ & $\mathrm{X}$ & $\mathrm{X}$ & $\mathrm{X}$ & $\mathrm{X}$ & $\mathrm{X}$ & $\mathrm{X}$ & & & & & & & & & & & & $35-620$ & $\mathrm{Sec}$ & Nat & \\
\hline Brachyrhaphis olomina & $\mathrm{X}$ & & & & & & $\mathrm{X}$ & & & & $\mathrm{X}$ & $\mathrm{X}$ & $\mathrm{X}$ & $\mathrm{X}$ & $\mathrm{X}$ & & & & $10-900$ & $\mathrm{Sec}$ & End & \\
\hline Brachyrhaphis parismina & $\mathrm{X}$ & $\mathrm{X}$ & $X$ & $X$ & $\mathrm{X}$ & $X$ & $\mathrm{X}$ & $\mathrm{X}$ & & & & & & & & & & & $5-50$ & $\mathrm{Sec}$ & Nat & \\
\hline Brachyrhaphis rhabdophora & & & & & & & & & & & & & & & & $X$ & $X$ & & $3-1450$ & $\mathrm{Sec}$ & End & \\
\hline Brachyrhaphis roseni & & & & & & & & & & & & & & & & & & $X$ & $20-100$ & $\mathrm{Sec}$ & Nat & \\
\hline Brachyrhaphis terrabensis & & & & & & & & & & & & & & & & $\mathrm{X}$ & $X$ & $X$ & $40-1450$ & $\mathrm{Sec}$ & Nat & \\
\hline Gambusia nicaraguensis & & & & & & & & $\mathrm{X}$ & & & & & & & & & & & $0-15$ & $\mathrm{Sec}$ & Nat & \\
\hline Phallichthys amates & $\mathrm{X}$ & $\mathrm{X}$ & $\mathrm{X}$ & $\mathrm{X}$ & $\mathrm{X}$ & $\mathrm{X}$ & $\mathrm{X}$ & $\mathrm{X}$ & $\mathrm{X}$ & & & $\mathrm{X}$ & $\mathrm{X}$ & & $\mathrm{X}$ & & & & $0-1120$ & $\mathrm{Sec}$ & Nat & \\
\hline Phallichthys quadripunctatus & & & & & & & & & $X$ & & & & & & & & & & $0-40$ & $\mathrm{Sec}$ & End & \\
\hline Phallichthys tico & $\mathrm{X}$ & & $X$ & $\mathrm{X}$ & $\mathrm{X}$ & & & & & & & & & & & & & & $35-600$ & $\mathrm{Sec}$ & Nat & \\
\hline Poecilia gillii & $\mathrm{X}$ & $\mathrm{X}$ & $\mathrm{X}$ & $\mathrm{X}$ & $\mathrm{X}$ & $\mathrm{X}$ & $\mathrm{X}$ & $\mathrm{X}$ & $\mathrm{X}$ & & $\mathrm{X}$ & $\mathrm{X}$ & $\mathrm{X}$ & $\mathrm{X}$ & $\mathrm{X}$ & $X$ & $\mathrm{X}$ & $\mathrm{X}$ & $0-1220$ & $\mathrm{Sec}$ & Nat & \\
\hline Poecilia mexicana & $\mathrm{X}$ & $\mathrm{X}$ & $X$ & $\mathrm{X}$ & $\mathrm{X}$ & $\mathrm{X}$ & $\mathrm{X}$ & $\mathrm{X}$ & & & & & & & & & & & $2-45$ & $\mathrm{Sec}$ & Nat & \\
\hline Poecilia reticulata & & & & & & & $\mathrm{X}$ & & & & & & & & $\mathrm{X}$ & & & & $30-1250$ & $\mathrm{Sec}$ & Exo & \\
\hline Poeciliopsis elongata & & & & & & & & & & & $\mathrm{X}$ & $X$ & $\mathrm{X}$ & $\mathrm{X}$ & $\mathrm{X}$ & $\mathrm{X}$ & $\mathrm{X}$ & $\mathrm{X}$ & $0-40$ & $\mathrm{Sec}$ & Nat & \\
\hline Poeciliopsis paucimaculata & & & & & & & & & & & & & & & & & $\mathrm{X}$ & $\mathrm{X}$ & $20-940$ & $\mathrm{Sec}$ & End & \\
\hline Poeciliopsis retropinna & & & & & & & & & & & & & & & & & $\mathrm{X}$ & $\mathrm{X}$ & $0-940$ & $\mathrm{Sec}$ & Nat & \\
\hline Poeciliopsis santaelena & & & & & & & & & & & $\mathrm{X}$ & & & & & & & & $90-115$ & $\mathrm{Sec}$ & End & $\mathrm{X}$ \\
\hline Poeciliopsis turrubarensis & & & & & & & & & & & $X$ & $\mathrm{X}$ & $\mathrm{X}$ & $\mathrm{X}$ & $\mathrm{X}$ & $\mathrm{X}$ & $\mathrm{X}$ & $\mathrm{X}$ & $0-120$ & $\mathrm{Sec}$ & Nat & \\
\hline Priapichthys annectens & $\mathrm{X}$ & $\mathrm{X}$ & $\mathrm{X}$ & $\mathrm{X}$ & $\mathrm{X}$ & $\mathrm{X}$ & $\mathrm{X}$ & $\mathrm{X}$ & $\mathrm{X}$ & & $\mathrm{X}$ & $\mathrm{X}$ & $\mathrm{X}$ & $\mathrm{X}$ & $\mathrm{X}$ & & & & $25-1270$ & $\mathrm{Sec}$ & End & \\
\hline Priapichthys panamensis & & & & & & & & & & & $\mathrm{X}$ & $\mathrm{X}$ & $\mathrm{X}$ & $\mathrm{X}$ & $\mathrm{X}$ & $\mathrm{X}$ & $\mathrm{X}$ & $\mathrm{X}$ & $0-95$ & $\mathrm{Sec}$ & Nat & \\
\hline Xenophallus umbratilis & $\mathrm{X}$ & $\mathrm{X}$ & $X$ & $\mathrm{X}$ & $\mathrm{X}$ & $\mathrm{X}$ & $\mathrm{X}$ & & & & & & $\mathrm{X}$ & & & & & & $35-590$ & $\mathrm{Sec}$ & Nat & \\
\hline Xiphophorus variatus & & & & & & & $\mathrm{X}$ & & & & & & & & & & & & 45 & $\mathrm{Sec}$ & Exo & \\
\hline
\end{tabular}


TABle 1. Continued.

\begin{tabular}{|c|c|c|c|c|c|c|c|c|c|c|c|c|c|c|c|c|c|c|c|c|c|c|}
\hline \multirow{2}{*}{ FAMILY/Species } & \multicolumn{9}{|c|}{ Atlantic slope } & \multicolumn{9}{|c|}{ Pacific slope } & \multirow{2}{*}{ Ele } & \multirow{2}{*}{ Sal } & \multirow{2}{*}{ CSt } & $f$ \\
\hline & LN & $\mathbf{R F}$ & SJ & SC & Sa & To & $\mathrm{Pa}$ & Ma & $\mathbf{S i}$ & IC & $\mathrm{Ni}$ & Te & $\mathrm{Be}$ & $\mathrm{Ba}$ & Ta & $\mathbf{P i}$ & $\operatorname{Tr}$ & Co & & & & Ald \\
\hline BELONIDAE (2) & & & & & & & & & & & & & & & & & & & & & & \\
\hline Strongylura marina & & & & & & $\mathrm{X}$ & & & & & & & & & & & & & $0-3$ & Per & Nat & $\mathrm{X}$ \\
\hline Strongylura timucu & & & & & & $\mathrm{X}$ & & $\mathrm{X}$ & & & & & & & & & & & $0-13$ & Per & Nat & $\mathrm{X}$ \\
\hline HEMIRAMPHIDAE (2) & & & & & & & & & & & & & & & & & & & & & & \\
\hline Hemiramphus brasiliensis & & & & & & $\mathrm{X}$ & & & & & & & & & & & & & $0-2$ & Per & Nat & $\mathrm{X}$ \\
\hline Hyporhamphus roberti & & & & & & $\mathrm{X}$ & & & & & & & & & & & & & $0-2$ & Per & Nat & $\mathrm{X}$ \\
\hline SYNGNATHIDAE (5) & & & & & & & & & & & & & & & & & & & & & & \\
\hline Microphis lineatus & & & & & & $\mathrm{X}$ & & $\mathrm{X}$ & $\mathrm{X}$ & & & & & & & & & & $0-12$ & Per & Nat & \\
\hline Pseudophallus elcapitanensis & & & & & & & & & & & $\mathrm{X}$ & $\mathrm{X}$ & $\mathrm{X}$ & $\mathrm{X}$ & $\mathrm{X}$ & $\mathrm{X}$ & $\mathrm{X}$ & $\mathrm{X}$ & $0-20$ & Per & Nat & \\
\hline Pseudophallus mindi & & & & & $\mathrm{X}$ & $\mathrm{X}$ & $\mathrm{X}$ & $\mathrm{X}$ & $\mathrm{X}$ & & & & & & & & & & $0-35$ & Per & Nat & \\
\hline Pseudophallus starksi & & & & & & & & & & & $\mathrm{X}$ & $\mathrm{X}$ & $\mathrm{X}$ & $\mathrm{X}$ & $\mathrm{X}$ & $\mathrm{X}$ & $\mathrm{X}$ & $\mathrm{X}$ & $0-155$ & Per & Nat & \\
\hline Syngnathus scovelli & & & & & & $\mathrm{X}$ & & & & & & & & & & & & & $0-3$ & Per & Nat & $\mathrm{X}$ \\
\hline SYNBRANCHIDAE (2) & & & & & & & & & & & & & & & & & & & & & & \\
\hline Synbranchus marmoratus & $\mathrm{X}$ & $\mathrm{X}$ & $\mathrm{X}$ & $\mathrm{X}$ & $\mathrm{X}$ & $\mathrm{X}$ & $\mathrm{X}$ & $\mathrm{X}$ & $\mathrm{X}$ & & $\mathrm{X}$ & $\mathrm{X}$ & $\mathrm{X}$ & $\mathrm{X}$ & $\mathrm{X}$ & $\mathrm{X}$ & $\mathrm{X}$ & $\mathrm{X}$ & $0-640$ & $\mathrm{Sec}$ & Nat & \\
\hline Ophisternon aenigmaticum & & $\mathrm{X}$ & & & & & & & & & & & & & & & & & 43 & Sec & Nat & $\mathrm{X}$ \\
\hline CENTROPOMIDAE (11) & & & & & & & & & & & & & & & & & & & & & & \\
\hline Centropomus armatus & & & & & & & & & & & & & & $\mathrm{X}$ & & & & & $0-6$ & Per & Nat & $\mathrm{X}$ \\
\hline Centropomus ensiferus & & & & & & $X$ & $\mathrm{X}$ & $X$ & $\mathrm{X}$ & & & & & & & & & & $0-11$ & Per & Nat & $X$ \\
\hline Centropomus medius & & & & & & & & & & & $\mathrm{X}$ & $X$ & $\mathrm{X}$ & $X$ & $\mathrm{X}$ & $\mathrm{X}$ & $\mathrm{X}$ & $\mathrm{X}$ & $0-250$ & Per & Nat & \\
\hline Centropomus mexicanus & & & & & & $\mathrm{X}$ & $\mathrm{X}$ & $\mathrm{X}$ & $\mathrm{X}$ & & & & & & & & & & $0-4$ & Per & Nat & $\mathrm{X}$ \\
\hline Centropomus nigrescens & & & & & & & & & & & $\mathrm{X}$ & $\mathrm{X}$ & $\mathrm{X}$ & $\mathrm{X}$ & $\mathrm{X}$ & $\mathrm{X}$ & $\mathrm{X}$ & $\mathrm{X}$ & $0-145$ & Per & Nat & $\mathrm{X}$ \\
\hline Centropomus parallelus & & $\mathrm{X}$ & $\mathrm{X}$ & $\mathrm{X}$ & $\mathrm{X}$ & $\mathrm{X}$ & $\mathrm{X}$ & $\mathrm{X}$ & $\mathrm{X}$ & & & & & & & & & & $0-43$ & Per & Nat & \\
\hline Centropomus pectinatus & & & & & & $\mathrm{X}$ & $\mathrm{X}$ & $\mathrm{X}$ & $\mathrm{X}$ & & & & & & & & & & $0-12$ & Per & Nat & \\
\hline Centropomus robalito & & & & & & & & & & & $\mathrm{X}$ & $\mathrm{X}$ & $\mathrm{X}$ & $\mathrm{X}$ & $\mathrm{X}$ & $\mathrm{X}$ & $\mathrm{X}$ & $\mathrm{X}$ & $0-50$ & Per & Nat & \\
\hline Centropomus undecimalis & & & & & & $\mathrm{X}$ & $\mathrm{X}$ & $\mathrm{X}$ & $\mathrm{X}$ & & & & & & & & & & $0-50$ & Per & Nat & \\
\hline Centropomus viridis & & & & & & & & & & & & $\mathrm{X}$ & & & & & $\mathrm{X}$ & & $0-145$ & Per & Nat & $\mathrm{X}$ \\
\hline Centropomus unionensis & & & & & & & & & & & & $\mathrm{X}$ & & & & $\mathrm{X}$ & & & $0-88$ & Per & Nat & $\mathrm{X}$ \\
\hline SERRANIDAE (1) & & & & & & & & & & & & & & & & & & & & & & \\
\hline Epinephelus guttatus & & & & & & $\mathrm{X}$ & & & & & & & & & & & & & $0-3$ & Per & Nat & $\mathrm{X}$ \\
\hline CENTRARCHIDAE (1) & & & & & & & & & & & & & & & & & & & & & & \\
\hline Micropterus salmoides & & & & & & & & & & & & & & & $\mathrm{X}$ & & & & 854 & Pri & Exo & \\
\hline CARANGIDAE (9) & & & & & & & & & & & & & & & & & & & & & & \\
\hline Carangoides vinctus & & & & & & & & & & & & & & & $\mathrm{X}$ & & & & $0-7$ & Per & Nat & $\mathrm{X}$ \\
\hline Caranx caballus & & & & & & & & & & & & & & & & & $\mathrm{X}$ & & $0-55$ & Per & Nat & $\mathrm{X}$ \\
\hline Caranx caninus & & & & & & & & & & & & & & & $\mathrm{X}$ & $X$ & $X$ & & $0-55$ & Per & Nat & $\mathrm{X}$ \\
\hline Caranx hippos & & & & & & $X$ & & $\mathrm{X}$ & & & & & & & & & & & $0-5$ & Per & Nat & $X$ \\
\hline Caranx latus & & & & & & $\mathrm{X}$ & $\mathrm{X}$ & $\mathrm{X}$ & $\mathrm{X}$ & & & & & & & & & & $0-20$ & Per & Nat & \\
\hline Hemicaranx amblyrhynchus & & & & & & $X$ & & & & & & & & & & & & & $0-3$ & Per & Nat & $X$ \\
\hline Oligoplites altus & & & & & & & & & & & & & & & & & $\mathrm{X}$ & $\mathrm{X}$ & $0-10$ & Per & Nat & $X$ \\
\hline Oligoplites palometa & & & & & $\mathrm{X}$ & $\mathrm{X}$ & & & & & & & & & & & & & $0-10$ & Per & Nat & \\
\hline Oligoplites saurus & & & & & & $X$ & & & & & & & & & & & & & $0-4$ & Per & Nat & $\mathrm{X}$ \\
\hline LUTJANIDAE (7) & & & & & & & & & & & & & & & & & & & & & & \\
\hline Lutjanus analis & & & & & & $\mathrm{X}$ & & $\mathrm{X}$ & & & & & & & & & & & $0-3$ & Per & Nat & $\mathrm{X}$ \\
\hline Lutjanus argentiventris & & & & & & & & & & & $\mathrm{X}$ & $\mathrm{X}$ & $\mathrm{X}$ & $\mathrm{X}$ & $\mathrm{X}$ & $\mathrm{X}$ & $\mathrm{X}$ & $\mathrm{X}$ & $0-20$ & Per & Nat & \\
\hline Lutjanus colorado & & & & & & & & & & $\mathrm{X}$ & & & & & & $\mathrm{X}$ & $\mathrm{X}$ & & $0-17$ & Per & Nat & $\mathrm{X}$ \\
\hline Lutjanus griseus & & & & & & $X$ & & & & & & & & & & & & & $0-3$ & Per & Nat & $X$ \\
\hline Lutjanus jocu & & & & & & $X$ & $\mathrm{X}$ & $\mathrm{X}$ & $\mathrm{X}$ & & & & & & & & & & $0-9$ & Per & Nat & $X$ \\
\hline Lutjanus jordani & & & & & & & & & & & & & & & & & $\mathrm{X}$ & & $0-145$ & Per & Nat & $\mathrm{X}$ \\
\hline Lutjanus novemfasciatus & & & & & & & & & & & & & & & $\mathrm{X}$ & $\mathrm{X}$ & $X$ & & $0-95$ & Per & Nat & $X$ \\
\hline GERREIDAE (11) & & & & & & & & & & & & & & & & & & & & & & \\
\hline Diapterus auratus & & & & & & $\mathrm{X}$ & & & & & & & & & & & & & $0-3$ & Per & Nat & $\mathrm{X}$ \\
\hline Diapterus peruvianus & & & & & & & & & & & & & & $\mathrm{X}$ & & $\mathrm{X}$ & $\mathrm{X}$ & & $0-10$ & Per & Nat & $X$ \\
\hline Diapterus rhombeus & & & & & & $\mathrm{X}$ & $\mathrm{X}$ & & & & & & & & & & & & $0-12$ & Per & Nat & $\mathrm{X}$ \\
\hline Eucinostomus argenteus & & & & & & & & $\mathrm{X}$ & & & & & & & & & & & $0-6$ & Per & Nat & $\mathrm{X}$ \\
\hline Eucinostomus currani & & & & & & & & & & & $\mathrm{X}$ & $\mathrm{X}$ & $\mathrm{X}$ & $\mathrm{X}$ & $\mathrm{X}$ & $\mathrm{X}$ & $\mathrm{X}$ & $\mathrm{X}$ & $0-145$ & Per & Nat & \\
\hline Eucinostomus dowii & & & & & & & & & & & & & & & & $X$ & & & $0-10$ & Per & Nat & $\mathrm{X}$ \\
\hline Eucinostomus melanopterus & & & & & & $\mathrm{X}$ & $\mathrm{X}$ & $\mathrm{X}$ & & & & & & & & & & & $0-10$ & Per & Nat & $\mathrm{X}$ \\
\hline Eugerres brevimanus & & & & & & & & & & & $\mathrm{X}$ & $\mathrm{X}$ & $\mathrm{X}$ & $\mathrm{X}$ & $\mathrm{X}$ & $\mathrm{X}$ & $\mathrm{X}$ & $\mathrm{X}$ & $0-145$ & Per & Nat & \\
\hline Eugerres plumieri & & & $\mathrm{X}$ & $\mathrm{X}$ & $\mathrm{X}$ & $X$ & & & & & & & & & & & & & $0-31$ & Per & Nat & \\
\hline Gerres cinereus & & & & & & $\mathrm{X}$ & & & & & & & & & & & & & $0-12$ & Per & Nat & $\mathrm{X}$ \\
\hline Gerres simillimus & & & & & & & & & & & $\mathrm{X}$ & & & & & $\mathrm{X}$ & $\mathrm{X}$ & & $0-640$ & Per & Nat & $\mathrm{X}$ \\
\hline
\end{tabular}


TABle 1. Continued.

\begin{tabular}{|c|c|c|c|c|c|c|c|c|c|c|c|c|c|c|c|c|c|c|c|c|c|c|}
\hline \multirow{2}{*}{ FAMILY/Species } & \multicolumn{9}{|c|}{ Atlantic slope } & \multicolumn{9}{|c|}{ Pacific slope } & \multirow{2}{*}{ Ele } & \multirow{2}{*}{ Sal } & \multirow{2}{*}{ CSt } & $f$ \\
\hline & LN & $\mathbf{R F}$ & SJ & SC & Sa & To & $\mathrm{Pa}$ & Ma & Si & IC & $\mathrm{Ni}$ & Te & $\mathrm{Be}$ & $\mathrm{Ba}$ & Ta & $\mathbf{P i}$ & $\operatorname{Tr}$ & Co & & & & Ald \\
\hline HAEMULIDAE (8) & & & & & & & & & & & & & & & & & & & & & & \\
\hline Conodon nobilis & & & & & & $\mathrm{X}$ & $\mathrm{X}$ & $\mathrm{X}$ & $\mathrm{X}$ & & & & & & & & & & $0-51$ & Per & Nat & $\mathrm{X}$ \\
\hline Haemulopsis corvinaeformis & & & & & & $\mathrm{X}$ & & & & & & & & & & & & & $0-5$ & Per & Nat & $\mathrm{X}$ \\
\hline Haemulopsis leuciscus & & & & & & & & & & & & & & & & & $\mathrm{X}$ & & $0-145$ & Per & Nat & $\mathrm{X}$ \\
\hline Pomadasys bayanus & & & & & & & & & & & $\mathrm{X}$ & $\mathrm{X}$ & $\mathrm{X}$ & $\mathrm{X}$ & $\mathrm{X}$ & $\mathrm{X}$ & $\mathrm{X}$ & & $0-640$ & Per & Nat & \\
\hline Pomadasys branickii & & & & & & & & & & & & & & & & & $\mathrm{X}$ & & $0-17$ & Per & Nat & $\mathrm{X}$ \\
\hline Pomadasys crocro & & & & & $\mathrm{X}$ & $\mathrm{X}$ & $\mathrm{X}$ & $\mathrm{X}$ & $\mathrm{X}$ & & & & & & & & & & $0-40$ & Per & Nat & \\
\hline Pomadasys empherus & & & & & & & & & & & & & & $\mathrm{X}$ & & & & & $0-10$ & Per & Nat & $\mathrm{X}$ \\
\hline Pomadasys macracanthus & & & & & & & & & & & & & & $\mathrm{X}$ & & & & & $0-32$ & Per & Nat & $\mathrm{X}$ \\
\hline SCIAENIDAE (5) & & & & & & & & & & & & & & & & & & & & & & \\
\hline Bairdiella ronchus & & & & & & $\mathrm{X}$ & & & & & & & & & & & & & $0-5$ & Per & Nat & $\mathrm{X}$ \\
\hline Cynoscion albus & & & & & & & & & & & & & $\mathrm{X}$ & & & & & & $0-6$ & Per & Nat & $\mathrm{X}$ \\
\hline Larimus breviceps & & & & & & $\mathrm{X}$ & & & & & & & & & & & & & $0-3$ & Per & Nat & $\mathrm{X}$ \\
\hline Micropogonias furnieri & & & & & & $\mathrm{X}$ & $\mathrm{X}$ & & & & & & & & & & & & $0-3$ & Per & Nat & $\mathrm{X}$ \\
\hline Ophioscion typicus & & & & & & & & & & & & & & & & & $\mathrm{X}$ & & $0-43$ & Per & Nat & $\mathrm{X}$ \\
\hline POLYNEMIDAE (1) & & & & & & & & & & & & & & & & & & & & & & \\
\hline Polydactylus virginicus & & & & & & $\mathrm{X}$ & $\mathrm{X}$ & $\mathrm{X}$ & & & & & & & & & & & $0-6$ & Per & Nat & $\mathrm{X}$ \\
\hline KYPHOSIDAE (1) & & & & & & & & & & & & & & & & & & & & & & \\
\hline Kyphosus sectatrix & & & & & & $\mathrm{X}$ & & & & & & & & & & & & & $0-3$ & Per & Nat & $\mathrm{X}$ \\
\hline MUGILIDAE (4) & & & & & & & & & & & & & & & & & & & & & & \\
\hline Agonostomus monticola & $\mathrm{X}$ & $\mathrm{X}$ & $\mathrm{X}$ & $\mathrm{X}$ & $\mathrm{X}$ & $\mathrm{X}$ & $\mathrm{X}$ & $\mathrm{X}$ & $\mathrm{X}$ & $\mathrm{X}$ & $\mathrm{X}$ & $X$ & $\mathrm{X}$ & $\mathrm{X}$ & $\mathrm{X}$ & $\mathrm{X}$ & $\mathrm{X}$ & $\mathrm{X}$ & $0-650$ & Per & Nat & \\
\hline Joturus pichardi & & & & & $\mathrm{X}$ & $\mathrm{X}$ & $\mathrm{X}$ & $X$ & $\mathrm{X}$ & & & & & & & & & & $0-600$ & Per & Nat & \\
\hline Mugil cephalus & & & & & & $\mathrm{X}$ & & & & & & & & & & & & & $0-3$ & Per & Nat & $\mathrm{X}$ \\
\hline Mugil curema & & & & & & $\mathrm{X}$ & $\mathrm{X}$ & $\mathrm{X}$ & $\mathrm{X}$ & & $\mathrm{X}$ & $\mathrm{X}$ & $\mathrm{X}$ & $\mathrm{X}$ & $\mathrm{X}$ & $\mathrm{X}$ & $\mathrm{X}$ & $\mathrm{X}$ & $0-145$ & Per & Nat & $\mathrm{X}$ \\
\hline CICHLIDAE (26) & & & & & & & & & & & & & & & & & & & & & & \\
\hline Amatitlania kanna & & & & & & & & & $\mathrm{X}$ & & & & & & & & & & $0-65$ & $\mathrm{Sec}$ & Nat & \\
\hline Amatitlania siquia & $\mathrm{X}$ & $\mathrm{X}$ & $\mathrm{X}$ & $\mathrm{X}$ & $\mathrm{X}$ & $\mathrm{X}$ & $\mathrm{X}$ & $\mathrm{X}$ & & & $\mathrm{X}$ & $\mathrm{X}$ & $\mathrm{X}$ & $\mathrm{X}$ & $\mathrm{X}$ & & & & $0-540$ & $\mathrm{Sec}$ & Nat & \\
\hline Amphilophus alfari & $\mathrm{X}$ & $\mathrm{X}$ & $\mathrm{X}$ & $\mathrm{X}$ & $\mathrm{X}$ & $\mathrm{X}$ & $\mathrm{X}$ & $\mathrm{X}$ & & & & $\mathrm{X}$ & $\mathrm{X}$ & & $\mathrm{X}$ & & & & $2-1150$ & $\mathrm{Sec}$ & Nat & \\
\hline Amphilophus altifrons & & & & & & & & & & & & & & & & & & $\mathrm{X}$ & $20-400$ & $\mathrm{Sec}$ & Nat & \\
\hline Amphilophus bussingi & & & & & & & & & $\mathrm{X}$ & & & & & & & & & & $40-150$ & $\mathrm{Sec}$ & End & \\
\hline Amphilophus citrinellus & $\mathrm{X}$ & $\mathrm{X}$ & $\mathrm{X}$ & $\mathrm{X}$ & $\mathrm{X}$ & $\mathrm{X}$ & $\mathrm{X}$ & $\mathrm{X}$ & & & & & & & & & & & $0-12$ & $\mathrm{Sec}$ & Nat & \\
\hline Amphilophus diquis & & & & & & & & & & & & & & & & $\mathrm{X}$ & $\mathrm{X}$ & $\mathrm{X}$ & $16-700$ & $\mathrm{Sec}$ & End & \\
\hline Amphilophus longimanus & $\mathrm{X}$ & $\mathrm{X}$ & $\mathrm{X}$ & $\mathrm{X}$ & $\mathrm{X}$ & $\mathrm{X}$ & & & & & $\mathrm{X}$ & $\mathrm{X}$ & $\mathrm{X}$ & & & & & & $0-100$ & $\mathrm{Sec}$ & Nat & \\
\hline Amphilophus lyonsi & & & & & & & & & & & & & & & & & & $\mathrm{X}$ & $10-20$ & $\mathrm{Sec}$ & Nat & \\
\hline Amphilophus rhytisma & & & & & & & & & $\mathrm{X}$ & & & & & & & & & & $40-60$ & $\mathrm{Sec}$ & Nat & \\
\hline Amphilophus rostratus & $\mathrm{X}$ & $X$ & $\mathrm{X}$ & $\mathrm{X}$ & $\mathrm{X}$ & $\mathrm{X}$ & $\mathrm{X}$ & $\mathrm{X}$ & & & & & & & & & & & $0-200$ & $\mathrm{Sec}$ & Nat & \\
\hline Andinoacara coeruleopunctatus & & & & & & & & & & & & & & & & & & $\mathrm{X}$ & $20-100$ & $\mathrm{Sec}$ & Nat & \\
\hline Archocentrus centrarchus & $\mathrm{X}$ & $\mathrm{X}$ & $\mathrm{X}$ & $\mathrm{X}$ & $\mathrm{X}$ & $\mathrm{X}$ & $\mathrm{X}$ & $\mathrm{X}$ & & & & & & & & & & & $0-45$ & $\mathrm{Sec}$ & Nat & \\
\hline Archocentrus multispinosus & $\mathrm{X}$ & $\mathrm{X}$ & $\mathrm{X}$ & $\mathrm{X}$ & $\mathrm{X}$ & $\mathrm{X}$ & $\mathrm{X}$ & $\mathrm{X}$ & & & $\mathrm{X}$ & $\mathrm{X}$ & $\mathrm{X}$ & & & & & & $0-75$ & $\mathrm{Sec}$ & Nat & \\
\hline Cryptoheros myrnae & & & & & & & & & $\mathrm{X}$ & & & & & & & & & & $40-150$ & $\mathrm{Sec}$ & End & \\
\hline Cryptoheros sajica & & & & & & & & & & & & & & & & $\mathrm{X}$ & $\mathrm{X}$ & $\mathrm{X}$ & $10-680$ & $\mathrm{Sec}$ & End & \\
\hline Cryptoheros septemfasciatus & $\mathrm{X}$ & $\mathrm{X}$ & $\mathrm{X}$ & $\mathrm{X}$ & $\mathrm{X}$ & $\mathrm{X}$ & $\mathrm{X}$ & $\mathrm{X}$ & & & & & & & & & & & $12-600$ & $\mathrm{Sec}$ & Nat & \\
\hline Hypsophrys nematopus & $\mathrm{X}$ & $\mathrm{X}$ & $\mathrm{X}$ & $\mathrm{X}$ & $\mathrm{X}$ & $\mathrm{X}$ & & & & & & & $\mathrm{X}$ & & & & & & $35-535$ & $\mathrm{Sec}$ & Nat & \\
\hline Hypsophrys nicaraguensis & $\mathrm{X}$ & $\mathrm{X}$ & $\mathrm{X}$ & $\mathrm{X}$ & $\mathrm{X}$ & $\mathrm{X}$ & $\mathrm{X}$ & $\mathrm{X}$ & & & & & $\mathrm{X}$ & & & & & & $5-200$ & $\mathrm{Sec}$ & Nat & \\
\hline Oreochromis niloticus & $\mathrm{X}$ & $\mathrm{X}$ & $\mathrm{X}$ & $\mathrm{X}$ & $\mathrm{X}$ & $\mathrm{X}$ & $\mathrm{X}$ & $\mathrm{X}$ & $\mathrm{X}$ & & $\mathrm{X}$ & & $\mathrm{X}$ & & $\mathrm{X}$ & & $\mathrm{X}$ & & $0-1250$ & $\mathrm{Sec}$ & Exo & $\mathrm{X}$ \\
\hline Parachromis dovii & $\mathrm{X}$ & $X$ & $X$ & $\mathrm{X}$ & $X$ & $X$ & $X$ & $\mathrm{X}$ & & & $X$ & $\mathrm{X}$ & $\mathrm{X}$ & & & & & & $0-600$ & $\mathrm{Sec}$ & Nat & \\
\hline Parachromis loisellei & $\mathrm{X}$ & $\mathrm{X}$ & $\mathrm{X}$ & $\mathrm{X}$ & $\mathrm{X}$ & $\mathrm{X}$ & $\mathrm{X}$ & $\mathrm{X}$ & $\mathrm{X}$ & & & & $\mathrm{X}$ & $\mathrm{X}$ & & & & & $1-70$ & $\mathrm{Sec}$ & Nat & \\
\hline Parachromis managuensis & $\mathrm{X}$ & $\mathrm{X}$ & $\mathrm{X}$ & $\mathrm{X}$ & $\mathrm{X}$ & $\mathrm{X}$ & $\mathrm{X}$ & $\mathrm{X}$ & $\mathrm{X}$ & & & & $\mathrm{X}$ & & & & & & $0-45$ & $\mathrm{Sec}$ & Nat & \\
\hline Tomocichla sieboldii & & & & & & & & & & & & & & & $X$ & $X$ & $X$ & $\mathrm{X}$ & $10-840$ & $\mathrm{Sec}$ & Nat & \\
\hline Tomocichla tuba & $\mathrm{X}$ & $\mathrm{X}$ & $\mathrm{X}$ & $\mathrm{X}$ & $\mathrm{X}$ & $\mathrm{X}$ & $\mathrm{X}$ & $\mathrm{X}$ & $\mathrm{X}$ & & & & & & & & & & $0-540$ & $\mathrm{Sec}$ & Nat & \\
\hline Vieja maculicauda & & & & & & $X$ & $\mathrm{X}$ & $X$ & $\mathrm{X}$ & & & & & & & & & & $0-5$ & $\mathrm{Sec}$ & Nat & \\
\hline LABRIDAE (2) & & & & & & & & & & & & & & & & & & & & & & \\
\hline Halichoeres aestuaricola & & & & & & & & & & & & & & & & $\mathrm{X}$ & $\mathrm{X}$ & & $0-17$ & Per & Nat & $\mathrm{X}$ \\
\hline Halichoeres notospilus & & & & & & & & & & & & & & & & & $X$ & & $0-15$ & Per & Nat & $\mathrm{X}$ \\
\hline DACTYLOSCOPIDAE (1) & & & & & & & & & & & & & & & & & & & & & & \\
\hline Dactyloscopus amnis & & & & & & & & & & & & & & $\mathrm{X}$ & & $\mathrm{X}$ & & & $0-10$ & Per & Nat & $\mathrm{X}$ \\
\hline BLENNIIDAE (1) & & & & & & & & & & & & & & & & & & & & & & \\
\hline Hypsoblennius maculipinna & & & & & & & & & & & & & & & & $X$ & & & $0-10$ & Per & Nat & $X$ \\
\hline ELEOTRIDAE (16) & & & & & & & & & & & & & & & & & & & & & & \\
\hline Dormitator latifrons & & & & & & & & & & & $\mathrm{X}$ & $X$ & $X$ & $X$ & $X$ & $X$ & $X$ & $X$ & $0-145$ & Per & Nat & \\
\hline Dormitator maculatus & & & & & & $X$ & $X$ & $X$ & $X$ & & & & & & & & & & $0-12$ & Per & Nat & \\
\hline
\end{tabular}


TABle 1. Continued.

\begin{tabular}{|c|c|c|c|c|c|c|c|c|c|c|c|c|c|c|c|c|c|c|c|c|c|c|}
\hline \multirow{2}{*}{ FAMILY/Species } & \multicolumn{9}{|c|}{ Atlantic slope } & \multicolumn{9}{|c|}{ Pacific slope } & \multirow{2}{*}{ Ele } & \multirow{2}{*}{ Sal } & \multirow{2}{*}{ CSt } & \multirow{2}{*}{ Af: } \\
\hline & LN & RF & SJ & SC & Sa & To & $\mathbf{P a}$ & Ma & Si & IC & $\mathbf{N i}$ & $\mathrm{Te}$ & $\mathrm{Be}$ & $\mathbf{B a}$ & Ta & $\mathbf{P i}$ & $\operatorname{Tr}$ & Co & & & & \\
\hline Eleotris amblyopsis & & & & & & $\mathrm{X}$ & $\mathrm{X}$ & $\mathrm{X}$ & $\mathrm{X}$ & & & & & & & & & & $0-15$ & Per & Nat & \\
\hline Eleotris picta & & & & & & & & & & $\mathrm{X}$ & $\mathrm{X}$ & $\mathrm{X}$ & $\mathrm{X}$ & $\mathrm{X}$ & $\mathrm{X}$ & $\mathrm{X}$ & $\mathrm{X}$ & $\mathrm{X}$ & $0-100$ & Per & Nat & \\
\hline Eleotris pisonis & & & & & & $\mathrm{X}$ & $\mathrm{X}$ & $\mathrm{X}$ & $\mathrm{X}$ & & & & & & & & & & $0-60$ & Per & Nat & \\
\hline Eleotris tecta & & & & & & & & & & & & & & & & & $\mathrm{X}$ & $\mathrm{X}$ & $0-75$ & Per & Nat & \\
\hline Eleotris tubularis & & & & & & & & & & $\mathrm{X}$ & & & & & & & & & $0-53$ & Per & End & $\mathrm{X}$ \\
\hline Erotelis armiger & & & & & & & & & & & & & & & & $\mathrm{X}$ & & & $0-10$ & Per & Nat & $\mathrm{X}$ \\
\hline Gobiomorus dormitor & $\mathrm{X}$ & $\mathrm{X}$ & $\mathrm{X}$ & $\mathrm{X}$ & $\mathrm{X}$ & $\mathrm{X}$ & $\mathrm{X}$ & $\mathrm{X}$ & $\mathrm{X}$ & & & & & & & & & & $0-60$ & Per & Nat & \\
\hline Gobiomorus maculatus & & & & & & & & & & & $\mathrm{X}$ & $\mathrm{X}$ & $\mathrm{X}$ & $\mathrm{X}$ & $\mathrm{X}$ & $\mathrm{X}$ & $\mathrm{X}$ & $\mathrm{X}$ & $0-145$ & Per & Nat & \\
\hline Gobiomorus polylepis & & & & & & & & & & & $\mathrm{X}$ & & & & & & & & $2-15$ & Per & Nat & \\
\hline Guavina guavina & & & & & & & & & $X$ & & & & & & & & & & $0-10$ & Per & Nat & $\mathrm{X}$ \\
\hline Guavina micropus & & & & & & & & & & & & & & & & & $\mathrm{X}$ & & $0-2$ & Per & Nat & $\mathrm{X}$ \\
\hline Hemieleotris latifasciata & & & & & & & & & & & $\mathrm{X}$ & $\mathrm{X}$ & $\mathrm{X}$ & $\mathrm{X}$ & $\mathrm{X}$ & $\mathrm{X}$ & $\mathrm{X}$ & $\mathrm{X}$ & $5-100$ & Per & Nat & \\
\hline Leptophilypnus fluviatilis & & & & & & $\mathrm{X}$ & & & & & & & & & & & & & $0-6$ & Per & Nat & $\mathrm{X}$ \\
\hline Leptophilypnus panamensis & & & & & & & & & & & & & & & $\mathrm{X}$ & $\mathrm{X}$ & $\mathrm{X}$ & & $0-32$ & Per & Nat & $\mathrm{X}$ \\
\hline \multicolumn{23}{|l|}{ GOBIIDAE (22) } \\
\hline Aboma etheostoma & & & & & & & & & & & & & & $\mathrm{X}$ & & & & & $0-32$ & Per & Nat & $\mathrm{X}$ \\
\hline Awaous banana & & & $\mathrm{X}$ & $\mathrm{X}$ & $\mathrm{X}$ & $\mathrm{X}$ & $\mathrm{X}$ & $\mathrm{X}$ & $\mathrm{X}$ & & & & $\mathrm{X}$ & & & & & & $0-300$ & Per & Nat & \\
\hline Awaous transandeanus & & & & & & & & & & & $\mathrm{X}$ & $\mathrm{X}$ & $\mathrm{X}$ & $\mathrm{X}$ & $\mathrm{X}$ & $\mathrm{X}$ & $\mathrm{X}$ & $\mathrm{X}$ & $0-120$ & Per & Nat & \\
\hline Bathygobius andrei & & & & & & & & & & & & & & $\mathrm{X}$ & $\mathrm{X}$ & $\mathrm{X}$ & $\mathrm{X}$ & & $0-32$ & Per & Nat & $\mathrm{X}$ \\
\hline Bathygobius ramosus & & & & & & & & & & $\mathrm{X}$ & & & & & & & $\mathrm{X}$ & & $0-10$ & Per & Nat & $\mathrm{X}$ \\
\hline Bathygobius soporator & & & & & & $\mathrm{X}$ & $\mathrm{X}$ & $\mathrm{X}$ & $\mathrm{X}$ & & & & & & & & & & $0-12$ & Per & Nat & $\mathrm{X}$ \\
\hline Ctenogobius boleosoma & & & & & & $\mathrm{X}$ & $\mathrm{X}$ & $\mathrm{X}$ & $\mathrm{X}$ & & & & & & & & & & $0-12$ & Per & Nat & $\mathrm{X}$ \\
\hline Ctenogobius fasciatus & & & & & & $\mathrm{X}$ & $\mathrm{X}$ & $\mathrm{X}$ & $\mathrm{X}$ & & & & & & & & & & $0-12$ & Per & Nat & $\mathrm{X}$ \\
\hline Ctenogobius pseudofasciatus & & & & & & $\mathrm{X}$ & & & & & & & & & & & & & $0-12$ & Per & Nat & $\mathrm{X}$ \\
\hline Ctenogobius sagittula & & & & & & & & & & & $\mathrm{X}$ & $\mathrm{X}$ & $\mathrm{X}$ & $\mathrm{X}$ & $X$ & $\mathrm{X}$ & $\mathrm{X}$ & & $0-32$ & Per & Nat & $\mathrm{X}$ \\
\hline Ctenogobius smaragdus & & & & & & $\mathrm{X}$ & & & & & & & & & & & & & $0-4$ & Per & Nat & $\mathrm{X}$ \\
\hline Evorthodus lyricus & & & & & & $\mathrm{X}$ & $\mathrm{X}$ & $\mathrm{X}$ & $\mathrm{X}$ & & & & & & & & & & $0-6$ & Per & Nat & $\mathrm{X}$ \\
\hline Evorthodus minutus & & & & & & & & & & & $\mathrm{X}$ & $\mathrm{X}$ & $\mathrm{X}$ & $\mathrm{X}$ & $\mathrm{X}$ & $\mathrm{X}$ & $\mathrm{X}$ & & $0-32$ & Per & Nat & $\mathrm{X}$ \\
\hline Gobioides broussonnetii & & & & & & $\mathrm{X}$ & $\mathrm{X}$ & & & & & & & & & & & & $0-3$ & Per & Nat & $\mathrm{X}$ \\
\hline Gobionellus microdon & & & & & & & & & & & $\mathrm{X}$ & $\mathrm{X}$ & $\mathrm{X}$ & $\mathrm{X}$ & $X$ & $X$ & $\mathrm{X}$ & & $0-32$ & Per & Nat & $\mathrm{X}$ \\
\hline Gobiosoma spes & & & & & & $\mathrm{X}$ & & & & & & & & & & & & & $0-3$ & Per & Nat & $\mathrm{X}$ \\
\hline Lophogobius cristulatus & & & & & & & & & & & & & & & & & $\mathrm{X}$ & & $0-17$ & Per & Nat & $\mathrm{X}$ \\
\hline Microgobius miraflorensis & & & & & & & & & & & & & & $\mathrm{X}$ & & & & & $0-32$ & Per & Nat & $\mathrm{X}$ \\
\hline Sicydium adelum & & & & & & & $\mathrm{X}$ & $\mathrm{X}$ & $\mathrm{X}$ & & & & & & & & & & $10-800$ & Per & End & \\
\hline Sicydium altum & & & & & $\mathrm{X}$ & $\mathrm{X}$ & $\mathrm{X}$ & $\mathrm{X}$ & $\mathrm{X}$ & & & & & & & & & & $0-1180$ & Per & Nat & \\
\hline Sicydium cocoensis & & & & & & & & & & $X$ & & & & & & & & & $0-62$ & Per & End & $\mathrm{X}$ \\
\hline Sicydium salvini & & & & & & & & & & & $\mathrm{X}$ & $\mathrm{X}$ & $\mathrm{X}$ & $\mathrm{X}$ & $\mathrm{X}$ & $\mathrm{X}$ & $\mathrm{X}$ & & $0-660$ & Per & Nat & \\
\hline \multicolumn{23}{|l|}{ MICRODESMIDAE (1) } \\
\hline Microdesmus dorsipunctatus & & & & & & & & & & & & & & & & $\mathrm{X}$ & & & $0-3$ & Per & Nat & $\mathrm{X}$ \\
\hline PARALICHTHYIDAE (4) & & & & & & & & & & & & & & & & & & & & & & \\
\hline Citharichthys arenaceus & & & & & & $\mathrm{X}$ & $\mathrm{X}$ & $\mathrm{X}$ & $\mathrm{X}$ & & & & & & & & & & $0-60$ & Per & Nat & $X$ \\
\hline Citharichthys gilberti & & & & & & & & & & & $\mathrm{X}$ & $\mathrm{X}$ & $\mathrm{X}$ & $\mathrm{X}$ & $\mathrm{X}$ & $\mathrm{X}$ & $\mathrm{X}$ & & $0-88$ & Per & Nat & $\mathrm{X}$ \\
\hline Citharichthys spilopterus & & & & & & $\mathrm{X}$ & $\mathrm{X}$ & $\mathrm{X}$ & $\mathrm{X}$ & & & & & & & & & & $0-60$ & Per & Nat & \\
\hline Citharichthys uhleri & & & & & & $\mathrm{X}$ & $\mathrm{X}$ & $\mathrm{X}$ & $\mathrm{X}$ & & & & & & & & & & $0-60$ & Per & Nat & \\
\hline ACHIRIDAE (7) & & & & & & & & & & & & & & & & & & & & & & \\
\hline Achirus declivis & & & & & & $X$ & $\mathrm{X}$ & & & & & & & & & & & & $0-3$ & Per & Nat & $\mathrm{X}$ \\
\hline Achirus lineatus & & & & & & $\mathrm{X}$ & & $\mathrm{X}$ & & & & & & & & & & & $0-5$ & Per & Nat & $\mathrm{X}$ \\
\hline Achirus mazatlanus & & & & & & & & & & & $\mathrm{X}$ & & & $\mathrm{X}$ & & $\mathrm{X}$ & & & $0-32$ & Per & Nat & $\mathrm{X}$ \\
\hline Trinectes fimbriatus & & & & & & & & & & & & & & $\mathrm{X}$ & & & & & $0-32$ & Per & Nat & $\mathrm{X}$ \\
\hline Trinectes fonsecensis & & & & & & & & & & & & & & $\mathrm{X}$ & $\mathrm{X}$ & $\mathrm{X}$ & $\mathrm{X}$ & & $0-55$ & Per & Nat & \\
\hline Trinectes inscriptus & & & & & & & & $\mathrm{X}$ & & & & & & & & & & & $0-5$ & Per & Nat & $\mathrm{X}$ \\
\hline Trinectes paulistanus & & & & & & $\mathrm{X}$ & $\mathrm{X}$ & $\mathrm{X}$ & $\mathrm{X}$ & & & & & & & & & & $0-10$ & Per & Nat & \\
\hline TETRAODONTIDAE (3) & & & & & & & & & & & & & & & & & & & & & & \\
\hline Sphoeroides annulatus & & & & & & & & & & & & & & $\mathrm{X}$ & & & $\mathrm{X}$ & & $0-5$ & Per & Nat & $\mathrm{X}$ \\
\hline Sphoeroides rosenblatti & & & & & & & & & & & & & & $\mathrm{X}$ & & & $\mathrm{X}$ & & $0-32$ & Per & Nat & $\mathrm{X}$ \\
\hline Sphoeroides testudineus & & & & & & $\mathrm{X}$ & & & & & & & & & & & & & $0-12$ & Per & Nat & $\mathrm{X}$ \\
\hline
\end{tabular}


ACKNOWLEDGMents: We thank to the staff of the Museo de Zoología, Escuela de Biología and the Centro de Investigación en Ciencias del Mar y Limnología (CIMAR) of the Universidad de Costa Rica, particularly to Ana Rosa Ramirez, Rita Vargas and Monika Springer for all the help and facilities offered. Many thanks to Bernald Pacheco and all AquaBiolab S.A. staff for partial support, arranging logistics and fieldwork. We are also very grateful to everyone who has contributed to this project with their fieldwork and/or partial support including: Beatriz Naranjo, Aldo Farah, Ana María Arias, Helena Molina, Gerardo Umaña, Prosanta Chakrabarty, Wilfredo Matamoros, Caleb McMahan, Michael Arroyo and Carlos Sánchez, among others. Finally, we also thank Wilfredo Matamoros and an anonymous reviewer for their valuable comments to the manuscript and their constructive suggestions.

\section{Literature Cited}

Albert, J.S. 2001. Species diversity and phylogenetic systematic of American knifefishes (Gymnotiformes, Teleostei). Miscellaneous Publications of the Museum of Zoology, University of Michigan 190: 1-127.

Albert, J.S. and R. Campos-da-Paz. 1998. Phylogenetic systematics of Gymnotiformes with diagnoses of 58 clades: a review of the available data; p. 419-446 In L.R. Malabarba, R.E. Reis, R.P. Vari, Z.M.S. Lucena and C.A.S. Lucena (ed.). Phylogeny and classification of neotropical fishes. Porto Alegre: EDIPUCRS.

Alda, F., A.G. Reina, I. Doadrio and E. Bermingham. 2013. Phylogeny and biogeography of the Poecilia sphenops species complex (Actinopterygii, Poeciliidae) in Central America. Molecular Phylogenetics and Evolution 66(3): 1011-1026.

Allen, G.R. and D.R. Robertson. 1994. Fishes of the tropical eastern Pacific. Bathurst: Crawford House Press. 332 p.

Allgayer, R. 2001. Description d'un genre nouveau, Cryptoheros, d'Amerique central et d'une espece nouvelle du Panama (Pisces: Cichlidae). L'an Cichlidé 1: 13-20.

Allgayer, R. 2002. Un cichlide nouveau du genre Tomocichla Regan, 1908 (Perciformes: Labroidei) du Rio Guarumo, Panama. L'an Cichlidé 2: 32-36.

Alpírez, O.Q. 1985. Ictiofauna de la vertiente Pacífica de Costa Rica. Brenesia 24: 297-318.

Angulo, A. 2013. Nombres comunes y técnicos de los peces de agua dulce de Costa Rica. Revista de Filología y Lingüística (accepted).

Angulo, A. and J.M. Gracian-Negrete. 2013. A new species of Brycon (Teleostei: Characiformes: Characidae) from Nicaragua and Costa Rica, with a key to the lower Mesoamerican species of the genus. Zootaxa (accepted).

Ardila-Rodríguez, C.A. 1994. Lebiasina floridablancaensis, una nueva especie de pez para Colombia (Teleostei: Characiformes: Lebiasinidae). Revista Unimetro 10(9): 1-8.

Ardila-Rodríguez, C.A. 1999. Lebiasina provenzanoi, una nueva especie de pez para Venezuela (Teleostei: Characiformes: Lebiasinidae). Revista Unimetro 13(5): 1-10.

Ardila-Rodríguez, C.A. 2000. Lebiasina yuruaniensis, una nueva especie de pez para Venezuela (Teleostei: Characiformes: Lebiasinidae). Revista Unimetro, Separata Especial 2(25): 1-16.

Ardila-Rodríguez, C.A. 2001. Lebiasina chucuriensis una nueva especie de pez para Colombia (Teleostei: Characiformes: Lebiasinidae). Revista Unimetro 13(27): 1-20.

Ardila-Rodríguez, C.A. 2002. Lebiasina nariñensis, una nueva especie de pez para Colombia (Teleostei: Characiformes, Lebiasinidae). Dahlia 5: $11-18$.

Ardila-Rodríguez, C.A. 2004. Lebiasina taphorni (Pisces: Characiformes, Lebiasinidae), una nueva especie. Dahlia 7: 57-65.

Ardila-Rodríguez, C.A. 2008a. Lebiasina ortegai (Characiformes: Lebiasinidae), nueva especie, sistema del río Cauca, Colombia. Dahlia 10: $17-25$.

Ardila-Rodríguez, C.A. 2008b. Lebiasina colombia (Characiformes: Lebiasinidae), nueva especie cuenca del río Sinú, Colombia. Dahlia 10: 27-32.

Ardila-Rodríguez, C.A. 2009. Lebiasina colombia (Ardila-Rodriguez, 2008). Peces del Alto río Sinu 1: 1-20.

Ardila-Rodríguez, C.A. 2010. Lebiasina chocoensis, una nueva especie de pez para Colombia (Teleostei: Characiformes: Lebiasinidae, Lebiasininae). Peces del Departamento del Chocó 1: 1-20.

Berkenkamp, H.O. and V. Etzel.1999. Die Rivulus-Arten von Panamá. Rivulus wassmanni spec. nov., eine neue Bachlingsart der Rivulus birkhahni-kuelpmanni-Gruppe aus der Provinz Bocas del Toro; Nordost-Panamá. Aquaristik aktuell 1999(7): 62-66.

Betancur-R, R. and A.P. Acero. 2004. Description of Notarius biffi n. sp. and redescription of N. Insculptus (Jordan and Gilbert) (Siluriformes: Ariidae) from the eastern Pacific, with evidence of monophyly and limits of Notarius. Zootaxa 703: 1-20.

Betancur-R, R. and A.P. Acero. 2006. A new species of Notarius (Siluriformes: Ariidae) from the Colombian Pacific. Zootaxa 1249:
47-59.

Bockmann, F.A. and G.M. Guazzelli, 2003. Family Heptapteridae; p. 406431 In R.E. Reis, S.O. Kullander and C.J. Ferraris (ed.). Check List of the Freshwater Fishes of South and Central America. Porto Alegre: EDIPUCRS.

Briggs, J.C. 1955. A monograph of the clingfishes (Order Xenopterygii). Stanford Ichthyological Bulletin 6: 1-224.

Bührnheim, C.M. and L.R. Malabarba. 2006. Redescription of the type species of Odontostilbe Cope, 187 (Teleostei: Characidae: Cheirodontinae), and description of three new species from the Amazon basin. Neotropical Ichthyology 4(2): 167-196.

Burgess, W.E. 1989. An atlas of freshwater and marine catfishes. A preliminary survey of the Siluriformes. Neptune City: T.F.H. Publications. 784 p.

Burgess, W.E. 2000. The Cichlasoma story. Herichthys, the break-up. Tropical Fish Hobbyist: 48(11): 44-54.

Bussing, W.A. 1980. Status of the cyprinodontid fish genus Rivulus in Costa Rica, with descriptions of new endemic species. Brenesia 17: 327-364.

Bussing, W.A. 1987. Peces de las aguas continentales de Costa Rica/ Freshwater fishes of Costa Rica. San José: Editorial Universidad de Costa Rica. 271 p.

Bussing, W.A. 1996. A new species of eleotridid, Eleotris tecta, from Pacific slope streams of tropical America (Pisces: Eleotrididae). Revista de Biologia Tropical 44(1): 251-257.

Bussing, W.A. 1996. Sicydium adelum, a new species of gobiid fish (Pisces: Gobiidae) from Atlantic slope streams of Costa Rica. Revista de Biologia Tropical 44(2): 819-825.

Bussing, W.A. 1998. Peces de las aguas continentales de Costa Rica/ Freshwater fishes of Costa Rica. San José: Editorial Universidad de Costa Rica. 468 p.

Bussing, W.A. 2008. A new species of poeciliid fish, Poeciliopsis santaelena, from Peninsula Santa Elena, Area de Conservación Guanacaste, Costa Rica. Revista de Biologia Tropical 56(2): 829-838.

Bussing, W.A. 2008. Astyanax cocibolca, a new characid (Pisces: Ostariophysi) from Lake Nicaragua, Central America. Revista de Biologia Tropical 56(3): 1361-1370.

Bussing, W.A. and M.I. López. 1994. Peces demersales y pelagicos costeros del Pacífico de Centro América Meridional: guía ilustrada/Demersal and pelagic inshore fishes of the Pacific coast of lower Central America: an illustrated guide. San José: Editorial Universidad de Costa Rica. $164 \mathrm{p}$.

Bussing, W.A. and M.I. López. 2005. Peces de la Isla del Coco y peces arrecifales de la costa pacífica de América Central Meridional: guía ilustrada/Fishes of Cocos Island and reef fishes of the pacific coast of lower Central America: an illustrated guide. San José: Editorial Universidad de Costa Rica. 192 p.

Bussing, W.A. and M.I. López. 2009. Marine fish; p. 453-458 In L.S. Wehrtmann and J. Cortés (ed.). Marine biodiversity of Costa Rica, Central America. New York: Springer.

Bussing, W.A. and M.I. López. 2010. Peces costeros del Caribe de Centroamérica Meridional: guía ilustrada/Marine fishes of the Caribbean coast of lower Central America: an illustrated guide. San José: Editorial Universidad de Costa Rica. 232 p.

Bussing, W.A. and M.I. López. 2011. Peces demersales y pelagicos costeros del Pacífico de Centro América Meridional: guía ilustrada/Demersal and pelagic inshore fishes of the Pacific coast of lower Central America: an illustrated guide. San José: Editorial Universidad de Costa Rica. $166 \mathrm{p}$.

Cabrera, J., C. Ampié, and G. Galeano. 1993. Presencia de Oreochromis niloticus (Pisces: Cichlidae) en las lagunas estacionales del Refugio Nacional Caño Negro, Costa Rica. Brenesia 38: 169-170.

Castro-Aguirre, J.L., H. Espinosa-Pérez and J.J. Schmitter-Soto. 1999. Ictiofauna estuarino-Lagunar y vicaria de México. Balderas: Editorial Limusa. 711 p.

Cervigón, F., R. Cipriani, W. Fischer, L. Garibaldi, M. Hendrickx, A.J. Lemus, R. Márquez, J.M. Poutiers, G. Robaina and B. Rodriquez. 1992. Guía de Campo de las Especies Comerciales Marinas y de Aguas Salobres de la Costa Septentrional de Sur America. Rome: FAO. 513 p.

Chakrabarty, P. 2007. A morphological phylogenetic analysis of Middle American cichlids with special emphasis on the section 'Nandopsis' sensu Regan. Miscellaneous Publications, Museum of Zoology, University of Michigan 198: 1-31.

Chakrabarty, P. and J.S. Sparks. 2007. Relationships of the New World cichlid genus Hypsophrys Agassiz 1859 (Teleostei: Cichlidae), with diagnoses for the genus and its species. Zootaxa 1523: 59-64.

Constantz, G.D., W.A. Bussing and W.G. Saul. 1981. Fresh-water fishes of Corcovado National Park, Costa Rica. Proceedings of the Academy of Natural Sciences of Philadelphia 133(1981): 15-19.

Costa, W.J.E.M. 2003. Family Rivulidae; p. 526-548 In R.E. Reis, S.O. Kullander and C.J. Ferraris (ed.). Check List of the Freshwater Fishes of South and Central America. Porto Alegre: EDIPUCRS. 
Costa, W.J.E.M. 2006. Relationships and taxonomy of the killifish genus Rivulus (Cyprinodontiformes: Aplocheiloidei: Rivulidae) from the Brazilian Amazonas River basin, with notes on historical ecology. Journal of Ichthyology and Aquatic Biology 11: 133-175.

Costa, W.J.E.M. 2011. Phylogenetic position and taxonomic status of Anablepsoides, Atlantirivulus, Cynodonichthys, Laimosemion and Melanorivulus (Cyprinodontiformes: Rivulidae). Ichthyological Exploration of Freshwaters 22(3): 233-249.

Dahl, G. 1971. Los Peces del norte de Colombia. Bogotá: Instituto de Desarrollo de Los Recursos Naturales Renovables (INDERENA). 391 p.

De la Cruz Agüero, J., M.A. Martínez, V.M.C. Gómez and G. De la Cruz Agüero. 1997. Catalogo de los peces marinos de Baja California Sur. La Paz, Baja California Sur: Instituto Politécnico Nacional, Centro Interdisciplinario de Ciencias Marinas. 346 p.

Devezé, P., J. Lorenzo and B. Sánchez. 2004. Cultivo de Poecilia reticulata (Pisces: Poecilidae) en cuerpos de agua tropicales, Veracruz, México. Revista de Biología Tropical 52(4): 951-958.

Dyer, B.S. and B. Chernoff. 1996. Phylogenetic relationships among atheriniform fishes (Teleostei: Atherinomorpha). Zoological Journal of the Linnean Society 117(1): 1-69.

Eigenmann, C.H. and W.R. Allen. 1942. Fishes of western South America. I. The Intercordilleran and Amazonian lowlands of Peru. II. The high pampas of Peru, Bolivia and northern Chile. Lexington: University of Kentucky. 494 p.

Eschmeyer, W.N. 2013. Catalog of Fishes electronic version. Electronic Database accessible at http://research.calacademy.org/ichthyology/ catalog/fishcatsearch.html. Captured on 22 January 2013.

Eschmeyer, W.N. and J.D. Fong. 2013. Species of Fishes by family/ subfamily. Electronic Database accessible at http://research. calacademy.org/research/ichthyology/catalog/SpeciesByFamily. html. Captured on 22 January 2013.

Froese, R. and D. Pauly. 2013. FishBase. Electronic Database accessible at http://www.fishbase.org. Captured on 22 January 2013.

Ferraris, C.J. Jr. 2003. Family Syngnathidae; p. 591-593 In R.E. Reis, S.O. Kullander and C.J. Ferraris (ed.). Check List of the Freshwater Fishes of South and Central America. Porto Alegre: EDIPUCRS.

Ferraris, C.J. Jr. 2007. Checklist of catfishes, recent and fossil (Osteichthyes: Siluriformes), and catalogue of siluriform primary types. Zootaxa 1418: 1-628.

Fisch-Muller, S. 2003. Family Ancistrinae; p. 373-400 In R.E. Reis, S.O. Kullander and C.J. Ferraris (ed.). Check List of the Freshwater Fishes of South and Central America. Porto Alegre: EDIPUCRS.

Fowler, H. 1932. Notes on fresh water fishes from Central America. Proceedings of the Academy of Natural Sciences of Philadelphia, 84(1932): 379-385.

Géry, J. 1977. Characoids of the World. Neptune City: Tropical Fish Hobbyist Publications. 672 p.

Gilbert, C.R. and D.P. Kelso. 1971. Fishes of the Tortuguero area, Caribbean Costa Rica. Bulletin of Florida State Museum Biological Sciences 16(1): 1-54.

Greenfield, D.W. and J.E. Thomerson. 1997. Fishes of the continental waters of Belize. Florida: University Press of Florida. $311 \mathrm{p}$.

Grove, J.S. and R.J. Lavenberg. 1997. The fishes of the Galapagos Islands. Palo Alto, California: Stanford University Press. 863 p.

Herrera, D.S. 2012. Identificacón de Pterygoplichthys en el río Reventazón, Costa Rica. Repertorio Científico 15(1): 3-6.

Isbrücker, I.J.H. 2001. Nomenklator der Gattungen und Arten der Harnischwelse, Familie Loricariidae Rafinesque, 1815 (Teleostei, Ostariophysi). DATZ Harnischwelse 2: 25-32.

Isbrücker, I.J.H. 2002. Nomenclator of the 108 genera with 692 species of the mailed catfishes, family Loricariidae Rafinesque, 1815 (Teleostei, Ostariophysi). Cat Chat, Journal of the catfish study group 3(1): 11-30.

Kihn-Pineda, P.H., E.B. Cano and A. Morales. 2006. Peces de las aguas interiores de Guatemala; p 457-486 In E.B. Cano (ed.). Biodiversidad de Guatemala. Guatemala: Universidad del Valle de Guatemala.

Kuiter, R.H. 2009. Seahorses and their Relatives. Seaford, Australia: Aquatic Photographics. 333 p.

Kullander, S.O. 2003. Family Cichlidae; p. 605-654 In R.E. Reis, S.O. Kullander and C.J. Ferraris (ed.). Check List of the Freshwater Fishes of South and Central America. Porto Alegre: EDIPUCRS.

Kullander, S.O. and K.E. Hartel. 1997. The systematic status of cichlid genera described by Louis Agassiz in 1859: Amphilophus, Baiodon, Hypsophrys and Parachromis (Teleostei: Cichlidae). Ichthyological Exploration of Freshwaters 7(3): 193-202.

Lima, F.C.T., L.R. Malabarba, P.A. Buckup, J.F. Pezzi da Silva, R.P. Vari, A. Harold, R. Benine, O.T. Oyakawa, C.S. Pavanelli, N.A. Menezes, C.A.S. Lucena, M.C.S.L.Z. Malabarba, M.S. Lucena, R.E. Reis, F. Langeani, L. Cassati, V.A. Bertaco, C. Moreira and P.H.F. Lucinda. 2003. Family Characidae, genera incertae sedis; p. 106-169 In R.E. Reis, S.O. Kullander and C.J. Ferraris (ed.). Check List of the Freshwater Fishes of South and Central America. Porto Alegre: EDIPUCRS.
Lody, E. 1978. Chromosome complement of the guppy, Poecilia reticulata Peters. (Pisces: Osteichthyes). Caryología 31(4): 475-477.

Loiselle, P.V. 1997. Diagnoses of two new cichlids from the Rio Sixaola Drainage, Costa Rica. Buntbarsche Bulletin 180: 1-8.

Lucinda, P.H.F. 2003. Poeciliidae, Livebearers; p. 555-581 In R.E. Reis, S.O. Kullander and C.J. Ferraris (ed.). Check List of the Freshwater Fishes of South and Central America. Porto Alegre: EDIPUCRS.

Lucinda, P.H.F. and T.E. Reis. 2005. Systematics of the subfamily Poeciliinae Bonaparte (Cyprinidontiformes: Poeciliidae), with an emphasis on the tribe Cnesterodontini Hubbs. Neotropical Ichthyology 3(1): 1-60.

Lyons, J. and D.W. Schneider. 1990. Factors influencing fish distribution and community structure in a small coastal River in southwestern Costa Rica. Hydrobiologia 203(1): 1-14.

Machado-Allison, A. 1974. Etapas del desarrollo del pez Piabucina pleurotaenia Regan 1903 (Characiformes: Lebiasinidae). Acta Biológica Venezoelana 8: 579-622.

Mago-Leccia, F. 1994. Electric fishes of the continental waters of America: classification and catalogue of the electric fishes of the order Gymnotiformes (Teleostei: Ostariophysi) with descriptions of new genera and species. Caracas: Fundación para el Desarrollo de las Ciencias Fisicas, Matematicas y Naturales. 219 p.

Malabarba, L.R. 2003. Subfamily Cheirodontinae; p. 215-221 In R.E. Reis, S.O. Kullander and C.J. Ferraris (ed.). Check List of the Freshwater Fishes of South and Central America. Porto Alegre: EDIPUCRS.

Malabarba, L.R. and S.H. Weitzman. 1999. A new genus and species of South American fishes (Teleostei: Characidae: Cheirodontinae) with a derived caudal fin, including comments about inseminating cheirodontines. Proceedings of the Biological Society of Washington 112: 410-432.

Malabarba, L.R. and S.H. Weitzman. 2000. A new genus and species of inseminating (Teleostei: Characidae: Cheirodontinae: Compsurini) from South America with uniquely derived caudal-fin dermal papillae. Proceedings of the Biological Society of Washington 113: 269-283.

Marceniuk, A.P. and N.A. Menezes. 2007. Systematics of the family Ariidae (Ostariophysi, Siluriformes), with a redefinition of the genera. Zootaxa 1416: 1-126.

Marceniuk, A.P., N.A. Menezes and M.R. Britto. 2012. Phylogenetic analysis of the family Ariidae (Ostariophysi: Siluriformes), with a hypothesis on the monophyly and relationships of genera. Zoological Journal of the Linnean Society 165(3): 534-669.

Matamoros, W.A., J.F. Schaefer and B.R. Kreiser. 2009. Annotated checklist of the freshwater fishes of continental and insular Honduras. Zootaxa 2307: 1-38.

Matamoros, W.A., P. Chakrabarty, A. Angulo, C.A. Garita-Alvarado and C.D. McMahan. 2013. A new species of Roeboides (Teleostei: Characidae) from Costa Rica and Panama, with a key to the middle American species of the genus. Neotropical ichthyology 11(2): 285-290.

McEachran, J.D. and J.D. Fechhelm. 2005. Fishes of the Gulf of Mexico. Volume 2: Scorpaeniformes to Tetraodontiformes. Austin: University of Texas Press. 1004 p.

McMahan, C.D., A.D. Geheberm and K.R. Piller. 2010. Molecular systematics of the enigmatic Middle American genus Vieja (Teleostei: Cichlidae). Molecular Phylogenetics and Evolution 57(3): 1293-1300.

McMahan, C.D., W.A. Matamoros, F.S. Álvarez-Calderón, W.Y. Henríquez, H.M. Recinos, P. Chakrabarty, E. Barraza and N. Herrera. 2013. Checklist of the inland fishes of El Salvador. Zootaxa 3608 (6): 440 456.

Meek, S.E. 1914. An annotated list of fishes known to occur in the freshwaters of Costa Rica. Field Museum of Natural History, Publications, Zoölogical Series 10(10): 101-134.

Mees, G.F. and P. Cala. 1989. Two new species of Imparfinis from northern South America (Pisces, Nematognathi, Pimelodidae). Proceedings of the Koninklijke Nederlandse Akademie van Wetenschappen 92(3): 379-394.

Meyer, M.K. and V. Etzel. 1998. Notes on the genus Brachyrhaphis Regan 1913, with the description of a new species from Panama (Pisces: Teleostei: Cyprinodontiformes: Poecilidae). Senckenbergiana Biologica 77(2): 155-160.

Meyer, M.K. and V. Etzel. 2001. Additional notes on the genus Brachyrhaphis Regan, 1913, with description of a new species from Panama (Teleostei: Cyprinodontiformes: Poeciliidae). Zoologische Abhandlungen 51(4): 33-39.

Miller, R.R., W.L. Minckley and S.M. Norris. 2005. Freshwater Fishes of México. Chicago: The University of Chicago Press. 490 p.

Mirande, J.M. 2010. Phylogeny of the family Characidae (Teleostei: Characiformes): from characters to taxonomy. Neotropical Ichthyology 8(3): 385-568.

Mojica, C.L., A. Meyer and G.W. Barlow. 1997. Phylogenetic relationships of species of the genus Brachyrhaphis (Poeciliidae) inferred from partial mitochondrial DNA sequences. Copeia 1997(2): 298-305.

Molina, A.A., D.S. Herrera and L.R. Rodríguez. 2010. Informe de peces 
diablo (Siluriformes: Loricáriidae) en la cuenca del río Reventazón, Costa Rica. Brenesia 73: 135-136.

Murdy, E.O. and D.F. Hoese. 2003. Gobiidae; p. 1781-1796 In K.E. Carpenter (ed.). The living marine resources of the Western Central Atlantic. Volume 3: Bony fishes part Two (Opistognathidae to Molidae). Rome: FAO.

Musilová, Z., O. Říçan and J. Novák. 2009. Phylogeny of the Neotropical cichlid fish tribe Cichlasomatini (Teleostei: Cichlidae) based on morphological and molecular data, with the description of a new genus. Journal of Zoological Systematics and Evolutionary Research 47(3): 234-247.

Myers, G.S. 1949. Salt-tolerance of fresh-water fish groups in relation to zoogeographical problems. Bijdragen tot de Dierkunde 28(1949): 315-322.

Myers, G.S. 1966. Derivation of the freshwater fish fauna of Central America. Copeia 1966(4): 766-733.

Nelson, J.S. 2006. Fishes of the world. New Jersey: John Wiley and Sons, Inc., Hoboken. 601 p.

Netto-Ferreira, A.L., O.T. Oyakawa, J. Zuanon and J.C. Nolasco. 2011. Lebiasina yepezi, a new Lebiasininae (Characiformes: Lebiasinidae) from the Serra Parima-Tapirapecó mountains. Neotropical Ichthyology 9(4): 767-775

Ornelas-Garcia, C.P., O. Dominguez-Dominguez and I. Doadrio. 2008. Evolutionary history of the fish genus Astyanax Baird and Girard (1854) (Actinopterygii, Characidae) in Mesoamerica reveals multiple morphological homoplasies. BMC Evolutionary Biology 8: 340.

Oro, G. and P. Cabrera. 1993. La tilapia Oreochromis niloticus (Pisces: Cichlidae) en el Caribe norte de Costa Rica. Revista de Biología Tropical 4(3): 920-921.

Ortega-Lara, A., N. Milani, C. DoNascimiento, F. Villa-Navarro and J.A. Maldonado-Ocampo. 2011. Two new trans-Andean species of Imparfinis Eigenmann and Norris, 1900 (Siluriformes: Heptapteridae) from Colombia. Neotropical Ichthyology 9(4): 777793.

Page, L.M. and B.M. Burr. 2011. Peterson field guide to freshwater fishes of North America north of Mexico. Freshwater Fishes of North America. Boston: Houghton Mifflin Harcourt. 663 pp.

Parenti, L.R., J.M. Clayton and J.C. Howe. 1999. Catalog of type specimens of Recent fishes in the National Museum of Natural History, Smithsonian Institution, 9: Family Poeciliidae (Teleostei: Cyprinodontiformes). Smithsonian Contributions to Zoology 604: 1-22.

Perdices, A., E. Bermingham, A. Montilla and I. Doadrio. 2002. Evolutionary history of the genus Rhamdia (Teleostei: Pimelodidae) in Central America. Molecular Phylogenetics and Evolution 25(1): 172-189.

Pezold, F. and B. Cage. 2002. A review of the spinycheek sleepers, genus Eleotris (Teleostei: Eleotridae), of the Western Hemisphere, with comparisons to the west African species. Tulane Studies in Zoology and Botany 31(2): 19-63.

Pizarro F. and J. Rojas. 1993. Presencia de Oreochromis niloticus en la desembocadura del río Bebedero, Golfo de Nicoya, Costa Rica. Revista de Biología Tropical 41(3): 921-924.

Ptacek, M.B. and F. Breden. 1998. Phylogenetic relationships among the mollies (Poeciliidae: Poecilia: Mollienesia) based on mitochondrial DNA sequences. Journal of Fish Biology 53: 64-82.

Radda, A.C. and M.K. Meyer. 1981. Revalidisierungder Gattung Xenophallus Huubs (Poeciliidae, Osteichthyes). Aquaria 28: 115-118.

Regan, C.T. 1907. Pisces; p 1-203 In F.D. Goldman and O. Salvin (ed.). Biologia Centrali-Americana. London: Porter, R.H.

Rojas, J.R. and O. Rodríguez. 2008. Diversidad y abundancia ictiofaunística del río Grande de Térraba, sur de Costa Rica. Revista de Biología Tropical 56(3): 1429-1447.

Román-Valencia, C. 2002. Revisión sistemática de las especies del género Bryconamericus (Teleostei: Characidae) de Centroamérica. Revista de Biología Tropical 50(1): 173-192.

Rosen, D.E. 1972. Origin of the characid fish genus Bramocharax and a description of a second, more primitive, species in Guatemala. American Museum Novitates 2500: 1-21.

Rosen, D.E. and R.M. Bailey. 1963. The poeciliid fishes (Cyprinodontiformes), their structure, zoogeography, and systematics. Bulletin of the American Museum of Natural History 126: 1-176.

Rosen, D.E. and P.H. Greenwood. 1976. A fourth neotropical species of synbranchid eel and the phylogeny and systematics of synbranchiform fishes. Bulletin of the American Museum of Natural History 157(1): 1-69.

Ruíz, R. 1978. Introducción de la Tilapia en Costa Rica. Aspectos fenotípicos y taxonómicos. Asbana 4: 6-10.

Saeed, B., W. Ivantsoff and L.E.L.M. Crowley. 1993. A new species of the surf-inhabiting atheriniform (Pisces: Isonidae). Records of the Western Australian Museum 16(3): 337-346.
Sáenz, I., M. Protti-Quesada and J. Cabrera. 2006. Composición de especies y diversidad de peces en un cuerpo de agua temporal en el Refugio Nacional de Vida Silvestre Caño Negro, Costa Rica. Revista de Biología Tropical 54(2): 639-645.

Scharpf, C. 2006. Annotated checklist of North American freshwater fishes, including subspecies and undescribed forms. Part II: Catostomidae through Mugilidae. American Currents 32: 1-40.

Schmitter-Soto, J.J. 2007a. A systematic revision of the genus Archocentrus (Perciformes: Cichlidae), with the description of two new genera and six new species. Zootaxa 1603: 1-76.

Schmitter-Soto, J.J. 2007b. Phylogeny of species formerly assigned to the genus Archocentrus (Perciformes: Cichlidae). Zootaxa 1618: 1-50.

Silfvergrip, A.M.C. 1996. A systematic revision of the neotropical catfish genus Rhamdia (Teleostei, Pimelodidae). Stockholm: Department of Zoology, Stockholm University and Department of Vertebrate Zoology, Swedish Museum of Natural History. 156 p.

Springer, V.G. and W.F. Smith-Vaniz. 2008. Supraneural and pterygiophore insertion patterns in carangid fishes, with description of a new Eocene carangid tribe, Paratrachinotini, and a survey of anterior anal-fin pterygiophore insertion patterns in Acanthomorpha. Bulletin of the Biological Society of Washington 16: 1-73.

Taphorn, D. 1992. Characiform fishes of the Apure River drainage, Venezuela. Guanare, Venezuela: BioLlania, UNELLEZ. 537 p.

Thacker, C.E., F. Pezold and R.D. Suttkus. 2006. Redescription of the dwarf Neotropical eleotrid genus Leptophilypnus (Teleostei: Gobioidei), including a new species and comments on Microphilypnus. Copeia 2006(3): 489-499.

Thorson, T.B. 1976. Observations on the Reproduction of the Sawfish, Pristis perotteti, in Lake Nicaragua, with Recommendations for its Conservation; p. 641-650 In T.B. Thorson (ed.). Investigations of the Ichthyofauna of Nicaraguan Lakes. Lincoln: University of NebraskaLincoln.

Thorson, T.B., C.M. Cowan and D.E. Watson. 1966. Sharks and sawfishes in the Lake Izabal-Rio Dulce system, Guatemala. Copeia 1966(3): 620622.

Urriola, M, J. Cabrera and M. Protti. 2004. Composición, crecimiento e índice de condición de una población de Poecilia reticulata (Pisces: Poeciliidae), en un estanque en Heredia, Costa Rica. Revista de Biología Tropical 52(1): 157-162.

Van Tassell, J.L. 2011. Gobiiformes of the Americas; p. 139-176 R.A. Patzner, J.L. Van Tassell, M. Kovacic and B.G. Kapoor (ed.). The biology of gobies. CRC Press, Science Publishers.

Vargas, R. 2003. Evaluación de la reproducción de trucha arcoirirs (Oncorhynchus mykiss) producida en Costa Rica. Agronomía Mesoamericana 14(1): 123-127.

Villa, J. 1982. Peces nicaraguenses de agua dulce. Managua: Editorial Unión Cardoza y Cía. Ltda. 253 p.

Weber, A. and H. Wilkens. 1998. Rhamdia macuspanensis: a new species of troglobitic pimelodid catfish (Siluriformes; Pimelodidae) from a cave in Tabasco, Mexico. Copeia 1998(4): 998-1004.

Weber, A., G. Allegrucci and V. Sbordoni. 2003. Rhamdia laluchensis, a new species of troglobitic catfish (Siluriformes: Pimelodidae) from Chiapas, Mexico. Ichthyological Exploration of Freshwaters 14(3): 273-280.

Weitzman, S.H. 1964. Osteology and relationships of South American characid fishes of subfamilies Lebiasinidae and Erythrinidae with special references to subtribe Nannostomina. Proceedings of the United States National Museum 116(3499): 127-170.

Welcomme, R.L. 1988. International introductions of inland aquatic species. Rome: FAO, Tech. Pap. 294. 318 pp.

Werner, U. 1983.Guapotes - die grossen Hübschen. Der Managubuntbarsch un sein Formenkreis. Aquarien Magazin 17: 396-401.

Winemiller, K.O.1983. An introduction to the freshwater fish communities of Corcovado National Park, Costa Rica. Brenesia 21: 47-66.

Winemiller, K.O. and M.A. Leslie. 1992. Fish communities across a complex freshwater-marine ecotone. Environmental Biology of Fishes 34(1): 29-50.

Winemiller, K.O. and N.E. Morales. 1989. Comunidades de peces del Parque Nacional Corcovado luego del cese de las actividades mineras. Brenesia 31: 75-91.

RECEIVED: July 2013

ACCEPTED: September 2013

Published ONLINE: October 2013

EDITORIAL REsPonsibility: Tiago Pinto Carvalho 